\title{
A COMPARATIVE ANALYSIS OF ENVIRONMENTAL AND ECONOMIC COSTS OF PV SOLAR IMPORTS AND MANUFACTURING FOR ONTARIO
}

by

Elizabeth Bich Ngoc Nguyen

Bachelor of Engineering in Biomedical Engineering, Ryerson University, 2014

\author{
A thesis \\ presented to Ryerson University \\ in partial fulfillment of the \\ requirements for the degree of \\ Master of Applied Science \\ in the Program of \\ Environmental Applied Science and Management
}

Toronto, Ontario, Canada, 2016

CElizabeth Bich Ngoc Nguyen 2016 


\section{Author's Declaration}

I hereby declare that I am the sole author of this thesis. This is a true copy of the thesis, including any required final revisions, as accepted by my examiners.

I authorize Ryerson University to lend this thesis to other institutions or individuals for the purpose of scholarly research.

I further authorize Ryerson University to reproduce this thesis by photocopying or by other means, in total or in part, at the request of other institutions or individuals for the purpose of scholarly research.

I understand that my thesis may be made electronically available to the public. 


\begin{abstract}
A COMPARATIVE ANALYSIS OF ENVIRONMENTAL AND ECONOMIC COSTS OF PV SOLAR IMPORTS AND MANUFACTURING FOR ONTARIO
\end{abstract}

Master of Applied Science, 2016

Elizabeth Bich Ngoc Nguyen

Environmental Applied Science and Management

Ryerson University

This research focuses on the environmental impacts related to the manufacturing of solar photovoltaic (PV) technology. The life cycle assessment (LCA) method was used to assess the environmental impacts for a CS6X-P module. The current supply chain, based in China, was compared to a hypothetical Ontario-based supply chain to determine environmental and economic costs. LCA results showed that the manufacturing of modules in Ontario reduced primary energy demands by $22 \%$ and GHG emission by $88 \%$. Moreover, the carbon difference between supply chains equated to $\$ 5.84$ per module. This leads to the conclusion that there are clear environmental benefits to manufacturing PV technology in Ontario; however, the economic benefits of carbon costing are not significant enough to encourage a complete shift in the current supply chain. It is suggested that a change in carbon policy could help to support the development of PV manufacturing and other renewable energy technologies in Ontario. 


\section{Acknowledgements}

I would like to extend my thanks and appreciation to my supervisor Dr. Phil Walsh.

I would also like to acknowledge the many friends, colleagues and professors who assisted, advised and supported my research and writing efforts.

Most of all I would like to thank my family, who have supported and encouraged me in all aspects of life. 


\section{Table of Contents}

Author's Declaration ..........................................................................................................

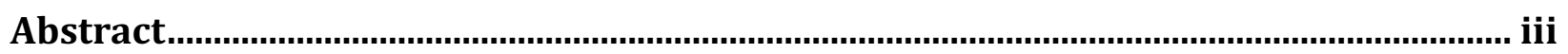

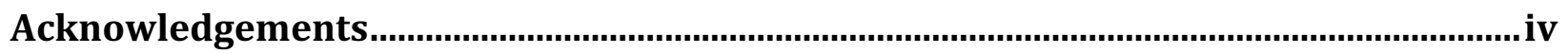

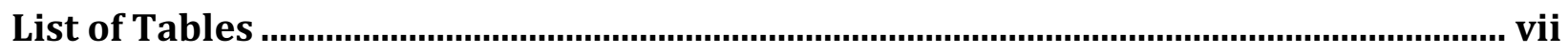

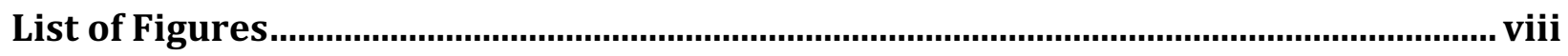

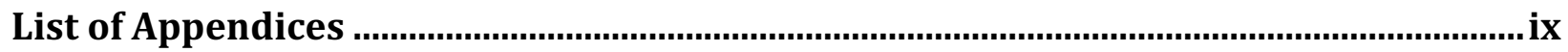

List of Terms and Abbreviations ……....................................................................... $\mathrm{x}$

1.0 Introduction

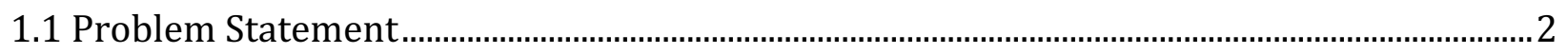

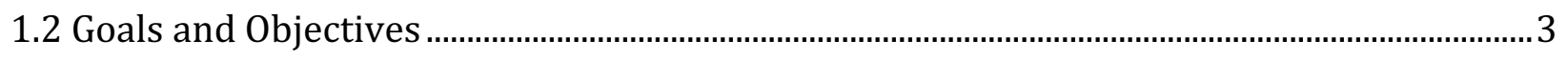

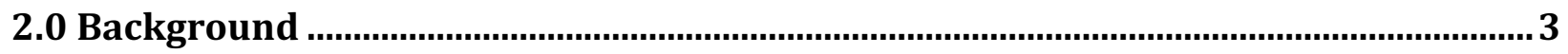

2.1 Energy Outlook......................................................................................................

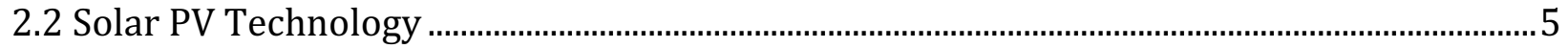

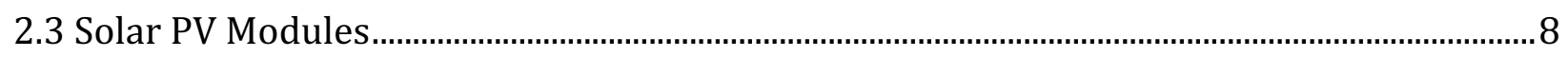

2.3.1 Crystalline Silicon Cells and Modules ...............................................................................

2.3.2 Preparation of Silicon and Transformation into Wafers .................................................10

2.3.3 Solar Cell Production....................................................................................................... 13

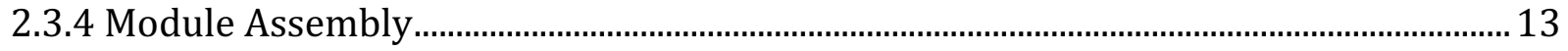

2.4 Global PV Supply Chain................................................................................................. 14

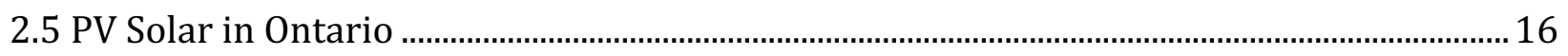

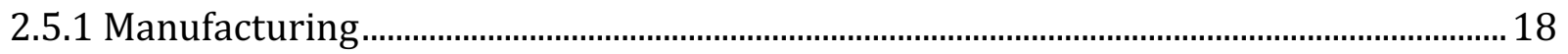

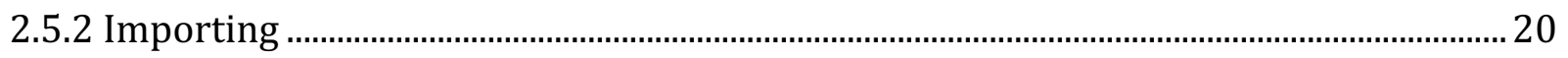

2.5.3 Developing an Ontario-based Supply Chain......................................................................22

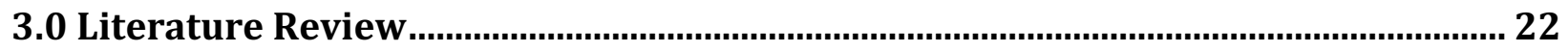

3.1 The Role of PVs in Sustainable Development …….............................................................. 22

3.2 Global Status of PV Market................................................................................................... 24

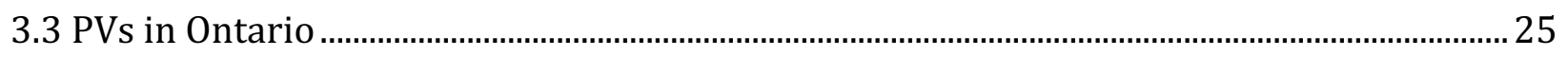

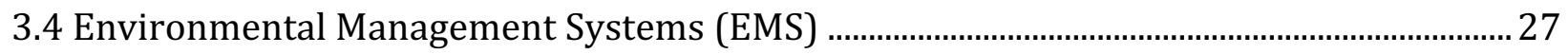

3.4.1 ISO 14000 Series for Environmental Management .......................................................... 27

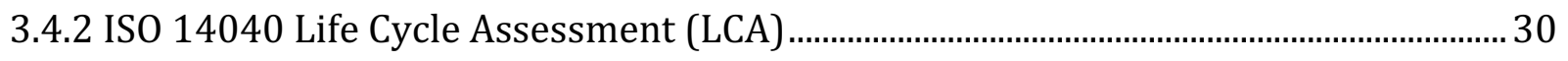

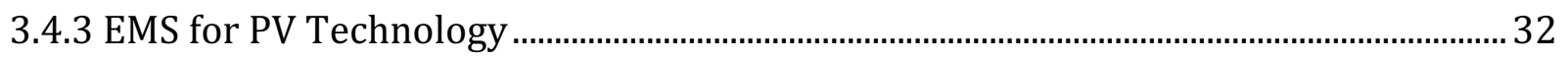

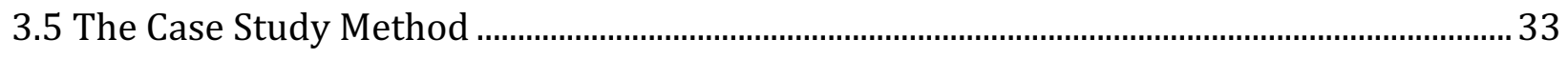

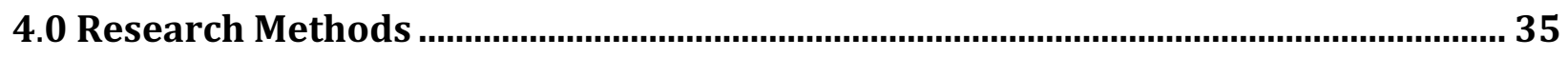

4.1 Case Study: Analysis of a mc-Si PV Module ........................................................................... 


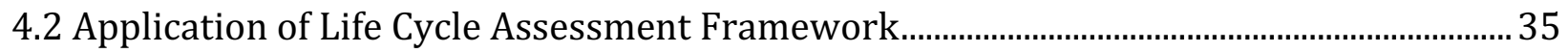

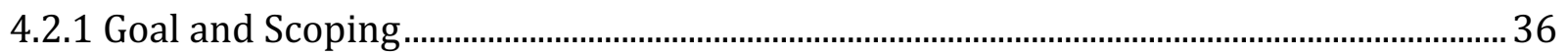

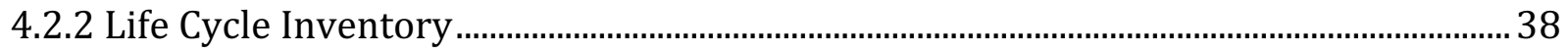

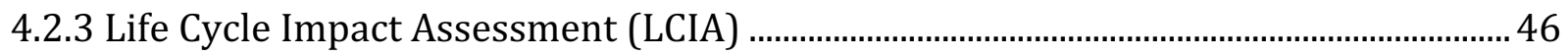

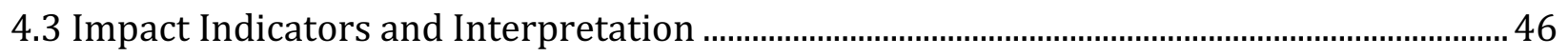

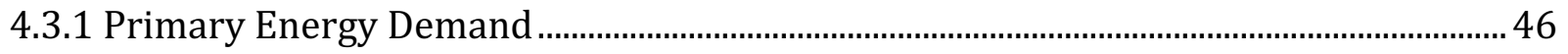

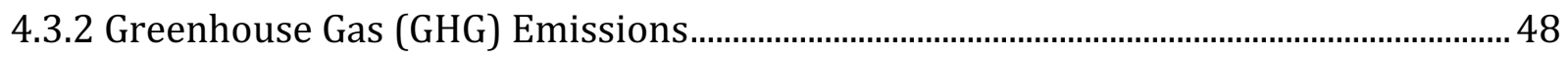

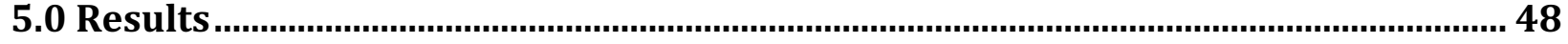

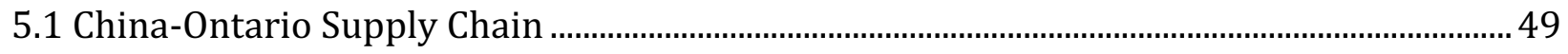

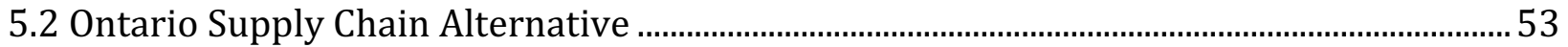

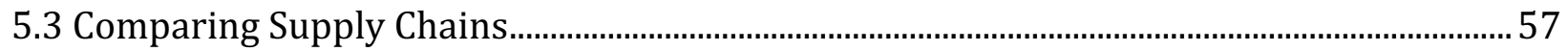

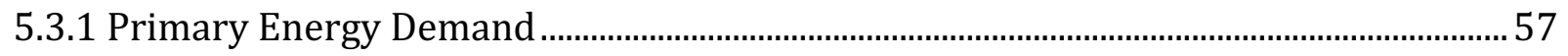

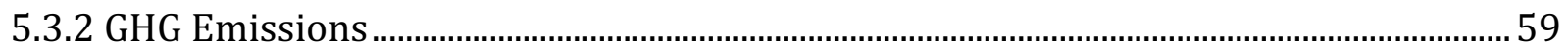

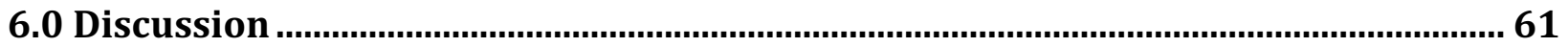

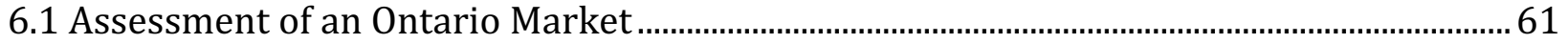

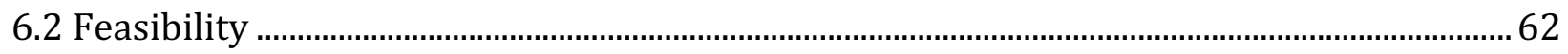

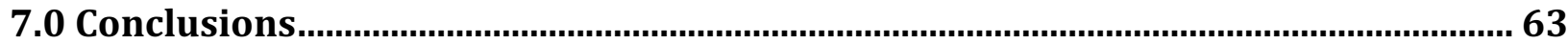

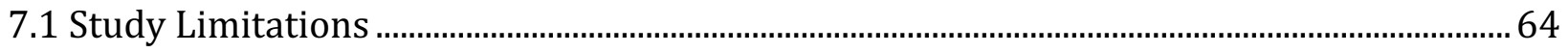

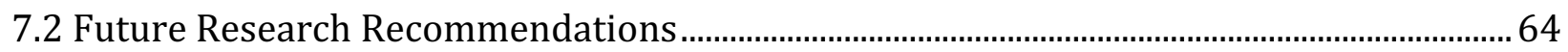

Appendices

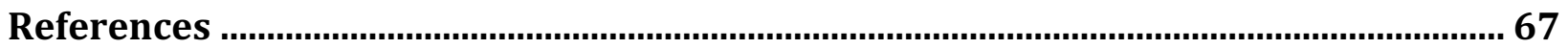




\section{List of Tables}

Table 1 - MicroFIT and FIT domestic activities and associated qualifying percentages

(Navigant Consulting Inc., 2012).

Table 2 - Manufacturer profile for 6N Silicon (Navigant Consulting Inc., 2012; Silicor Materials, 2012).

Table 3 - Manufacturer profile for Canadian Solar Solutions Inc. (Navigant Consulting Inc., 2012; Canadian Solar Inc., 2015).

Table 4 - Estimated margins of dumping, estimated amount of subsidy, and provisional duties by exporter (CBSA, 2015).

Table 5 - Supply volumes and market mixes of polysilicon used in wafer production and wafer production volumes (Frischknecht et al., 2015).......................................................2 25

Table 6 - Supply volumes and market mixes of wafers used in cell production and production volumes of cells (Frischknecht et al., 2015)......................................................25

Table 7 - "Types" of case study ………..................................................................................... 34

Table 8 - Primary parameters for a CS6X-320P mc-Si PV module under Standard Test Conditions (STC) of irradiance of $1000 \mathrm{~W} / \mathrm{m}^{2}$, spectrum AM 1.5 and cell temperature

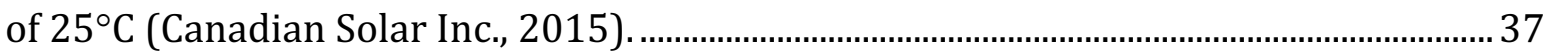

Table 9 - LCI data for mg-smelting (Frischknecht et al., 2015).................................................... 40

Table 10 - LCI data for sog-Si purification (Frischknecht et al., 2015)......................................... 41

Table 11 - LCI data for mc-Si ingot and wafer production (Frischknecht et al., 2015)........... 42

Table 12 - LCI data for mc-Si cell processing (Frischknecht et al., 2015).................................. 43

Table 13 - LCI data for mc-Si PV module assembly (Frischknecht et al., 2015)........................ 45

Table 14 - Flow balance for the production of the CS6X-320P PV module assuming a Chinese supply chain weighted to represent the gross calorific energy demand from nonrenewable and renewable resources [MJ].

Table 15 - Flow balance for the production of the CS6X-320P PV module assuming a Chinese supply chain using the CML global warming potential (GWP 100 years) weighting system $\left[\mathrm{kg} \mathrm{CO}^{2}\right.$-eq per panel]

Table 16 - Flow balance for the production of the CS6X-320P PV module assuming an Ontario supply chain weighted to represent the gross calorific primary energy demand from nonrenewable and renewable resources $[\mathrm{MJ}]$. 55

Table 17 - Flow balance for the production of the CS6X-320P PV module assuming an Ontario supply chain using the CML global warming potential (GWP 100 years)

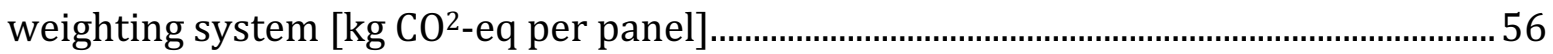
Table 18 - Electricity production and $\mathrm{CO}^{2}$ emissions for Ontario (IEA, 2015; IESO, 2015).. 58 Table 19 - Calculated results of impact assessment for CS6X-320P mc-Si PV module. 61 


\section{List of Figures}

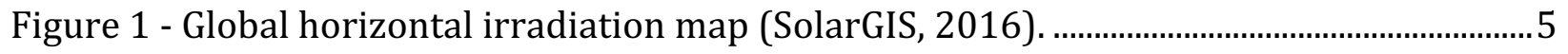

Figure 2 - Solar installed capacity for world regions (WEC, 2015)............................................6

Figure 3 - Single crystalline cell (left) versus mc-Si cell (right) (Photowatt, n.d.)...................... 9

Figure 4 - Process steps for mc-Si module production adopted from Navigant Consulting

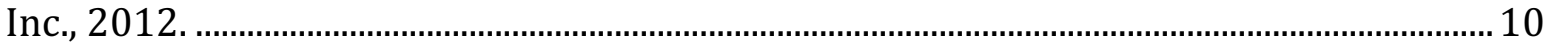

Figure 5 - A schematic approach for purifying mg-Si into sog-Si using a modified Siemens

process (Khattak, Joyce, \& Schmid, 2001)......................................................................... 12

Figure 6 - A cross section illustration of a mc-Si module......................................................... 14

Figure 7 - The PV supply chain (Navigant Inc., 2012). ................................................................15

Figure 8 - Annual PV potential (kWh/kW) for Canada developed by the Canadian Forest Service in collaboration with CanmetENERGY Photovoltaic systems group (NRCan, 2013).

Figure 9 - Environmental management tools for ISO 14000 series (Finkbeiner et al., 1998).

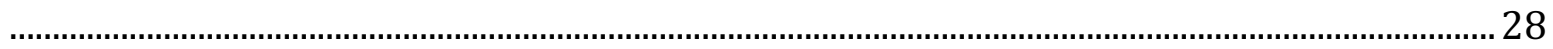

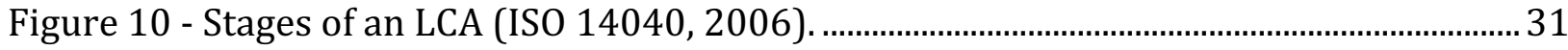

Figure 11 - The different system boundary types for an LCA (ISO 14040, 2006)...................... 31

Figure 12 - "Cradle-to-gate" system boundary constructed for a PV module using GaBi

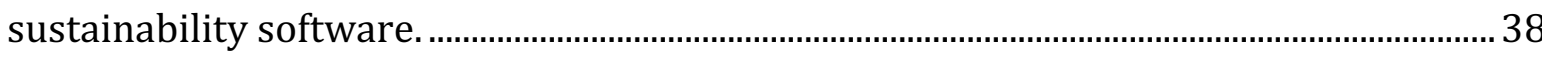

Figure 13 - Classification categories for process data inputs/outputs (ISO 14040, 2006)...39

Figure 14 - Ontario energy output by fuel type (IESO, 2015)..................................................5

Figure 15 - Comparing primary energy demand totals between China and Ontario for each unit process of the CS6X-320P mc-Si PV module life cycle.................................................... 58

Figure 16 - The global warming potential compared between China and Ontario for each unit process of the CS6X-320P mc-Si PV module life cycle..................................................... 60 


\section{List of Appendices}

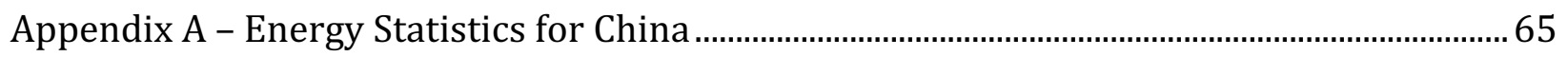

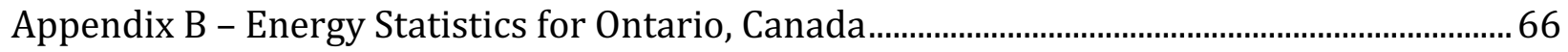




\section{List of Terms and Abbreviations}

$\begin{array}{ll}\text { BOS } & \text { balance of system } \\ \text { CBSA } & \text { Canadian Border Services Agency } \\ \text { EPBT } & \text { energy payback time } \\ \text { EROI } & \text { energy return on investment } \\ \text { EVA } & \text { ethylene vinyl acetate } \\ \text { FIT } & \text { feed-in tariff } \\ \text { GEA } & \text { Green Energy and Green Economy Act, 2009 } \\ \text { GHG } & \text { greenhouse gas } \\ \text { GWP } & \text { global warming potential } \\ \text { IEA } & \text { International Energy Agency } \\ \text { IESO } & \text { Independent Electricity System Operator } \\ \text { IPCC } & \text { Intergovernmental Panel on Climate Change } \\ \text { ISO } & \text { International Organization for Standardization } \\ \text { kWh } & \text { kilowatt-hour } \\ \text { LCA } & \text { life cycle assessment } \\ \text { LCIA } & \text { life cycle impact assessment } \\ \text { LTEP } & \text { Long-Term Energy Plan } \\ \text { mc-Si } & \text { multi-crystalline silicon } \\ \text { mg-Si } & \text { metallurgical silicon } \\ \text { NEA } & \text { National Energy Administration of China } \\ \text { NRCan } & \text { Natural Resources Canada } \\ \text { OPA } & \text { Ontario Power Authority } \\ \text { PCM } & \text { potential for carbon mitigation } \\ \text { PED } & \text { primary energy demand } \\ \text { PV } & \text { photovoltaic } \\ \text { sog-Si } & \text { solar grade silicon } \\ \text { WEC } & \text { World Energy Council } \\ & \end{array}$




\subsection{Introduction}

Energy is fundamental to meeting basic human needs and serving productive processes (Moomaw et al., 2011). The increase in energy consumption, along with the rapid rise in fossil fuel combustion and the corresponding release of $\mathrm{CO}_{2}$ emissions are major contributors to climate change (IPCC, 2011). As a result, the reduction of $\mathrm{CO}_{2}$ emissions and a shift towards renewable energy technologies are now on the global agenda, as climate change becomes a greater concern.

A considerable amount of research has been done on the development and implementation of sustainable renewable energy as an option to mitigate the effects of climate change. The IPCC Special Report on Renewable Energy Sources and Climate Change Mitigation describes the criteria for renewable resources to be sustainable:

“...it must be inexhaustible and not damage the delivery of environmental goods and services including the climate system ... must also be economically affordable over the long term; it must meet societal needs and be compatible with social norms now and in the future." (Moomaw et al., 2011, p. 174).

Moreover, renewable technologies have a substantially lower environmental impact when compared to conventional energy systems (Pehnt, 2006). All of which support the potential of renewable energy to mitigate global climate change.

Solar energy is abundant and considered one of the best energy resources for future development (Kreith \& Kreider, 1978; IEA, 2015). Solar technology can supply heating, cooling, natural lighting, electricity and fuels for a wide range of applications. By offering a suite of energy needs and services, solar energy provides opportunities of positive social and economic development necessary in decreasing our environmental impact and dependency on fossil fuels.

Currently solar electricity generation using photovoltaics (PVs) only represents a small fraction of the global energy supply; however, markets for solar technology are growing rapidly. Over the past 30 years, technological advances and supportive public policies have driven down the cost of solar technologies (Environment Canada, 2012; IEA, 2015). 
In Canada, the solar industry grew annually by more than 22\% between 1993 and 2009 (Environment Canada, 2012). However, continued growth of this industry becomes difficult when competing against foreign production in China, who are leaders in the solar industry for manufacturing. The manufacturing phase of the lifecycle is a critical point for solar technology. Environmental concern is raised over the energy demands, emissions and wastes that arise from this life stage and its respective unit processes. More than half of all emissions related to solar energy, which contribute to climate change, are emitted during the manufacturing phase (Hondo, 2005; Dubey, Jadhav, \& Zakirova, 2013; Nugent \& Sovacool, 2014). While the development of solar energy can offer us environmental and economic benefits, its development as a sustainable renewable resource during manufacturing is an important consideration for future generations. Therefore, it is important to assess the manufacturing life stage of solar energy to gain a better understanding of all environmental impacts associated with solar PV technology before we can recommend successful widespread adoption.

\subsection{Problem Statement}

Solar energy is a clean technology for electricity generation; however, there is a carbon footprint related to the manufacturing of solar PV modules. Life cycle assessments (LCAs) are a tool used to evaluate the environmental impacts that arise from the different life stages of a product or service. Research on solar PV modules shows a large variation in LCA results due to assumptions and estimates for local process parameters at the demand site. China is the world's largest producer of solar PV modules, while Canada has a small market share. This research will compare these two supply chain scenarios by performing a LCA to evaluate how local parameters unique to the demand site influence the manufacturing phase. The material and energy flows from the existing Chinese supply chain compared to those from an Ontario-based supply chain will have different effects on the overall environmental impacts of solar technology. Social, economic, environmental, and political perspectives will be used to compare the two supply chain scenarios. The pros/cons of each supply chain will be considered to argue the potential improvements that can be made to the current supply chain and how Ontario can develop a larger role in the solar PV industry. 


\subsection{Goals and Objectives}

Much of the research and development for solar energy has been focused on the throughput and yield rather than improved manufacturing (Arvizu et al., 2011). The environmental impacts of manufacturing have been evaluated in literature using a LCA approach; however, lack of reliable data derived from secondary data sources and estimations of local parameters have produced inconsistent results. Moreover, previous studies have mainly focused on production in China, paying no attention to the growing Ontario solar PV market. This research will address the following objectives:

i. Identify the unit processes involved in the life cycle of solar PV module manufacturing

ii. Break down how the PV supply chain functions and how it impacts Ontario manufacturing

iii. Perform a life cycle assessment for PV manufacturing for two supply chain scenarios to estimate the different potential impacts of solar PV technology

This research will use a case study method to compare supply chain scenarios for China and Ontario. The LCA approach will be used to examine environmental impacts for each case and answer the questions, "What is the environmental cost associated with manufacturing solar PV technology?" and "What indicators are there to support a growing Ontario-based supply chain, if any?" The product that will be studied is a multi-crystalline silicon (mc-Si) PV module manufactured by Canadian Solar, a solar manufacturer based out of Guelph, Ontario with additional manufacturing in China as well.

\subsection{Background}

This section will briefly discuss the global energy outlook and how renewable technologies, specifically solar, will be used to mitigate the effects of climate change. The PV market in Ontario continues to grow and should be prepared to adapt and change given the current status and future trends of solar technology. This research is focused on the manufacturing phase of solar technology, excluding the use and disposal phases. Details on the raw material extraction, material processing, manufacturing and assembly of mc-Si PV modules will be 
reviewed. Currently, the majority of the manufacturing unit processes occur in China, dominating the PV supply chain. However, Canadian companies who do contribute to the supply chain will be examined and an alternative Ontario-based supply chain will be developed.

\subsection{Energy Outlook}

In July 2015, the world's population reached 7.3 billion people and it is projected that in 2016, an additional 83 million more people will be added (United Nations, 2015). Since approximately 1850, global energy demands have been dominated by fossil fuels and have led to the rapid growth of $\mathrm{CO}_{2}$ emissions contributing to climate change (IPCC, 2011). The development of renewable energy technologies is important for mitigating climate change while also satisfying the global demand for energy services.

\section{Solar Energy}

Solar energy is modular, allowing for use in both centralized and decentralized energy systems. It is a readily available resource with some variability in energy output based on the temporal profile of solar irradiance (Arvizu et al., 2011). Solar technology can help to provide energy access to remote communities, particularly for the 1.4 billion people without access to electricity and the additional 1.3 billion still using traditional biomass (IPCC, 2011). It is considered the most promising renewable energy option for future sustainable development (Kreith \& Kreider, 1978; IEA, 2015).

\section{Resource Potential}

Solar irradiance is the amount of light energy from the sun reaching a surface per unit area per unit time (Kreith \& Kreider, 1978). It is measured at the Earth's surface after atmosphere absorption and scattering. NASA has measured the average annual solar irradiance entering our atmosphere at 1360 watts per square meter $\left(\mathrm{W} / \mathrm{m}^{2}\right)$ (Lindsey, 2009). When averaged for the whole planet, solar irradiance is measured at $340 \mathrm{~W} / \mathrm{m}^{2}$, often referred to as the theoretical potential irradiance. After losses from partial absorption and scattering, the technical potential irradiance is closer to $170 \mathrm{~W} / \mathrm{m}^{2}$ (Lindsey, 2009; Labouret \& Villoz, 2010; IEA, 2015). 
When irradiance is integrated over time it is called irradiation or insolation. It is a function of distance from the sun, solar cycle and cross-cycle changes or seasonal changes. The available solar potential or irradiation can be used by solar PV technology to generate usable electricity; however, the amount of irradiation is directly proportional to electricity output. The global horizontal potential irradiation is shown in Fig.1 (SolarGIS, 2016). The minimum and maximum range for total solar energy technical potential varies for different regions of the world. The tropics, from 0 to $23.5^{\circ}$ latitude, receive the most solar energy year round compared to other regions (Lindsey, 2009). However, in other parts of the world the annual solar resource is almost uniform; $200 \mathrm{~W} / \mathrm{m}^{2}$ a day in Australia, $185 \mathrm{~W} / \mathrm{m}^{2}$ a day in the United States, and $105 \mathrm{~W} / \mathrm{m}^{2}$ in the United Kingdom, making it possible for applications of solar energy to provide significant contributions to global energy mixes (IPCC, 2011; Goswami \& Besarati, 2013).

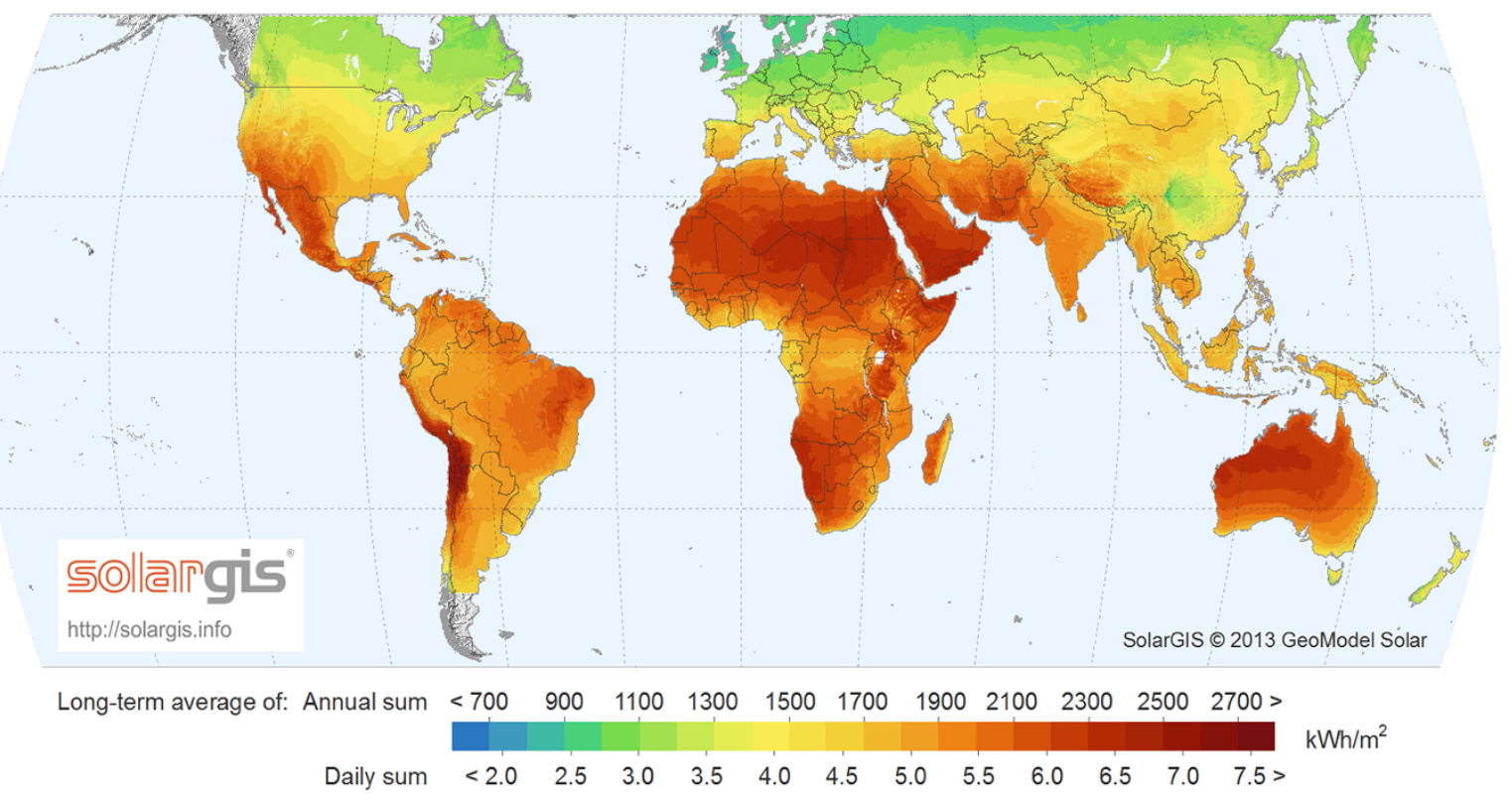

Figure 1 - Global horizontal irradiation map (SolarGIS, 2016).

\subsection{Solar PV Technology}

The use of solar PV technology to produce energy has grown substantially over the years and led the reduction in carbon emissions. In 2014, the global cumulative capacity for solar PV grew by 40.1 gigawatts (GW) or $28 \%$ and by end of year was reported to be 177 GW (IEA, 2015). This is sufficient enough to meet $1 \%$ of the world's total electricity needs. While cumulative capacity describes the maximum electric output an electricity generator can 
output under ideal conditions, installed capacity describes sustained output of a facility such as a power plant. According to the World Energy Council (WEC) (2015), the current global solar installed capacity is at $68.8 \mathrm{GW}$ with over 70 percent contribution from Europe (Figure 2).

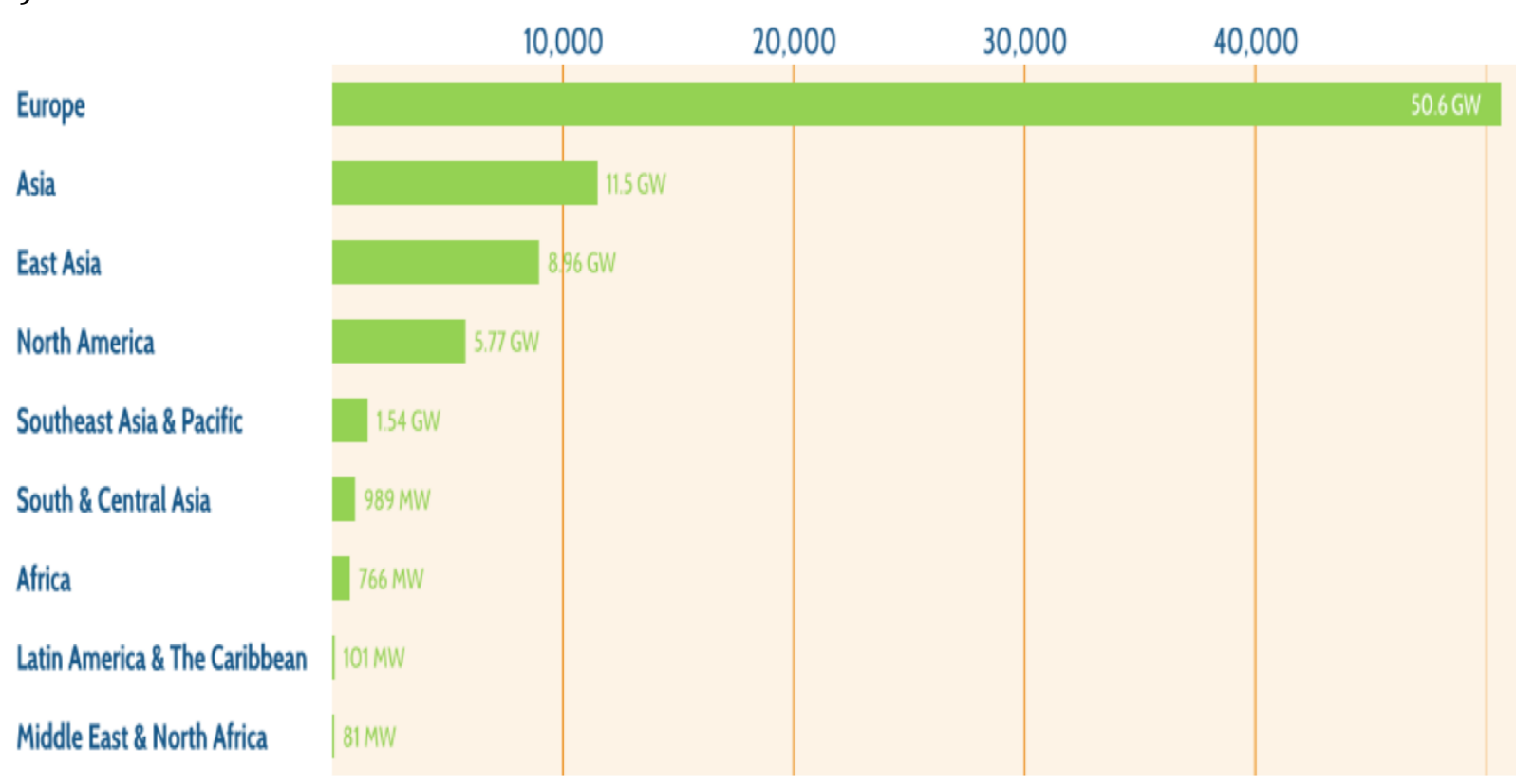

Figure 2 - Solar installed capacity for world regions (WEC, 2015).

PV technology exploits the solar irradiation reaching the earth's surface by converting direct light into electricity. This process is referred to as the photovoltaic effect and was first described in 1839 by Edmund Becquerel (Jungbluth, Stucki, Frischknecht, \& Büsser, 2010; Labouret \& Villoz, 2010). It was not until the 1930s that it became a more widely known phenomenon, when Albert Einstein received a Nobel Prize for his theories dealing with the photovoltaic effect (Jungbluth et al., 2010). Bell Laboratories made the first solar cell from silicon in 1954 and NASA subsequently used it in 1958 for the Vanguard project, the world's first solar-powered satellite (Arvizu et al., 2011; NSSDC, 2014). By the 1970s, in response to the oil crisis, programs for solar energy research and development (R\&D) were developed for terrestrial applications of solar PVs (Kreith \& Kreider, 1978; Gribov \& Zinov'ev, 2003).

While the technology for photovoltaic conversion had been well developed, the widespread application of solar energy was hampered by the high price of solar cells. In 1972, solar energy cost approximately $\$ 100$ US per electric watt, more than 100 times the cost of electric energy from conventional fossil fuel electric power plants (Kreith \& Kreider, 1978). By the 
1990s, technological advancements leading to reduced manufacturing costs and subsidy programs to support the early deployment of solar photovoltaic systems helped to grow the global PV market.

From 2003 to 2009, the PV market has grown by an impressive average annual rate of $40 \%$ and about $135 \%$ in 2010 (IEA, 2011). Currently, PV systems contribute to $0.1 \%$ of the worldwide electricity supply (Environment Canada, 2012). It is expected that PV technology will continue to grow as the production processes improve and new technologies are developed. The IEA (2011) believes that the future deployment of solar PV energy technology will supply up to $11 \%$ of global electricity by 2050 as renewable technologies will play a larger role in providing energy services.

\section{Photovoltaic Conversion}

Solar power is the conversion of sunlight energy into electric energy. The light contains energy particles called photons, which exhibit wave-particle duality (Kreith \& Kreider, 1978). This means that the amount of energy carried by a photon particle is dependent on its wavelength and frequency (Labouret \& Villoz, 2010; IEA, 2011). Photons with a high frequency will have high energy and photons with longer wavelengths will have less energy, frequency has an inverse relationship to wavelength. There are certain materials, that when exposed to light, undergo chemical and physical changes to create voltage or current. This is called the photovoltaic effect (Labouret \& Villoz, 2010).

Solar cells are diodes made from semiconductor materials such as silicon. When light strikes the material, the following optical events can occur: reflection, transmission (passing through), or absorption. Only light that is absorbed can be converted into electricity. Absorbed photons will transfer their energy to electrons in the valence band, these excited electrons will jump to the conduction band and become free or unbound electrons (Labouret \& Villoz, 2010). A junction created by the semiconductor creates an electric field to align positive charges to one side and negative charges to another side. The charge separation creates an electromotive force resulting in light energy being converted to electrical energy (Labouret \& Villoz, 2010). When the cell is connected to a load, electrons flow generating a direct current that is converted to an alternating current to provide usable power. The power 
generated is proportional to the amount of sunlight being received and the cells conversion efficiency (Environment Canada, 2012). Conversion efficiency is described as a ratio of power output to unit area $\left(\mathrm{W} / \mathrm{m}^{2}\right)$ for incident solar irradiance (Arvizu et al., 2011). The maximum potential for solar cells is dependent on absorber material properties and device design. There are a variety of PV systems that consist of different types of solar cells made of different semiconductor material and layer arrangements, which when exposed to light will undergo the photovoltaic effect with certain efficiency.

\subsection{Solar PV Modules}

PV modules or systems are arrays of solar cells that are electrically connected for electricity generation (Jungbluth et al., 2010). Additional components, "balance of system" (BOS) components, are used to convert direct current to alternating current as well as help regulate charge (Frankl, Menichetti, Raugei, Lombardelli, \& Prennushi, 2005).

PV cells can be made of organic or non-organic material. Organic cells use molecular or polymer absorbers; they have low cell efficiency, in the range of 11\% (IEA, 2011; U.S. DOE, 2015). Most solar technology is inorganic, based on silicon or non-silicon materials; they are classified as wafer-based cells and thin-film cells (Arvizu et al., 2011). Wafer-based or crystalline silicon cells lead the industry with over $80 \%$ of the market share (Frankl et al., 2005; Labouret \& Villoz, 2010).

\subsubsection{Crystalline Silicon Cells and Modules}

Solar cells are fabricated from silicon, the second most abundant element and the most abundant semiconductor material on Earth (Environment Canada, 2012). It is used as a semiconductor because it is tetravalent, meaning it can form four covalent bonds and crystallize into a diamond lattice, sometimes called an intrinsic semiconductor that can conduct small amounts of current, playing an important role in its ability to convert solar energy to electric energy (Stoppato, 2008; Ceccaroli \& Lohne, 2011). This along with its other material properties makes silicon an attractive option for fabrication of solar cells.

Crystalline silicon technology includes solar cells that are made of either single crystalline or mc-Si wafers with an average thickness of $200 \mu \mathrm{m}$ (Arvizu et al., 2011). Single crystalline silicon cells consist of a single layer of crystals. The cells have a uniform appearance since 
the atomic layers of the crystal are all oriented in the same direction and as a result have a higher cell efficiency of about 14-20 percent (Figure 3) (Frankl et al., 2005; Environment Canada, 2012). Mc-Si cells are comprised of single crystalline clusters oriented in different directions. The grain boundaries between clusters cause electron-hole recombination losses, and as a result produce lower cell efficiencies, about 11-16 percent (Jungbluth et al., 2010). While multi-crystalline production uses more silicon material than single crystalline production, the manufacturing processes are more simplified. The lower production costs for mc-Si results in affordable costs for consumers. For these reasons, mc-Si cells represent 45 percent of all crystalline silicon technologies currently on the market (Environment Canada, 2012).

The manufacturing process for mc-Si silicon PV modules can be divided into several steps: refinement of silicon into solar-grade silicon, wafer cutting, cell fabrication, and module assembly (Figure 4) (Frankl et al., 2005; Fthenakis, Kim, \& Alsema, 2008; Jungbluth et al., 2010). The process for mc-Si is considered well established and reliable; however, the material costs can be high and the feedstock production can be highly energy intensive (Frankl et al., 2005; Pehnt, 2006). This is an important area for environmental improvement since they have the highest impacts.

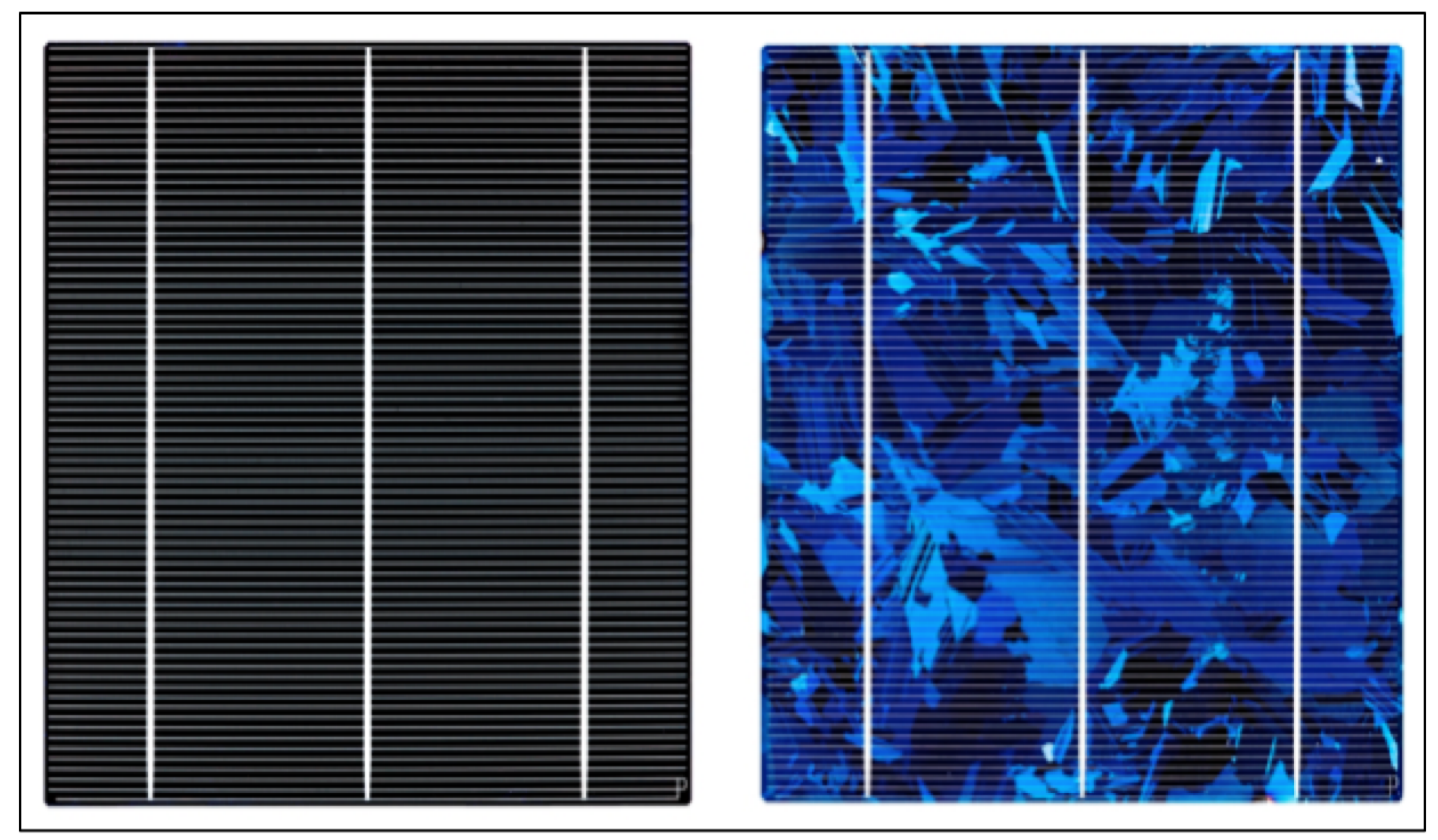

Figure 3 - Single crystalline cell (left) versus mc-Si cell (right) (Photowatt, n.d.). 


\subsubsection{Preparation of Silicon and Transformation into Wafers}

\section{Metallurgical Silicon}

The basic product of the global silicon market is metallurgical silicon (mg-Si), which has an approximate purity of 98.5-99.5 percent (Ceccaroli \& Lohne, 2011; Dubey et al., 2013). The main impurities of mg-Si are aluminum and iron. It is primarily used as an additive for aluminum and steel manufacturing but a portion of total production will be further purified for the electronic and solar industries (Labouret \& Villoz, 2010).

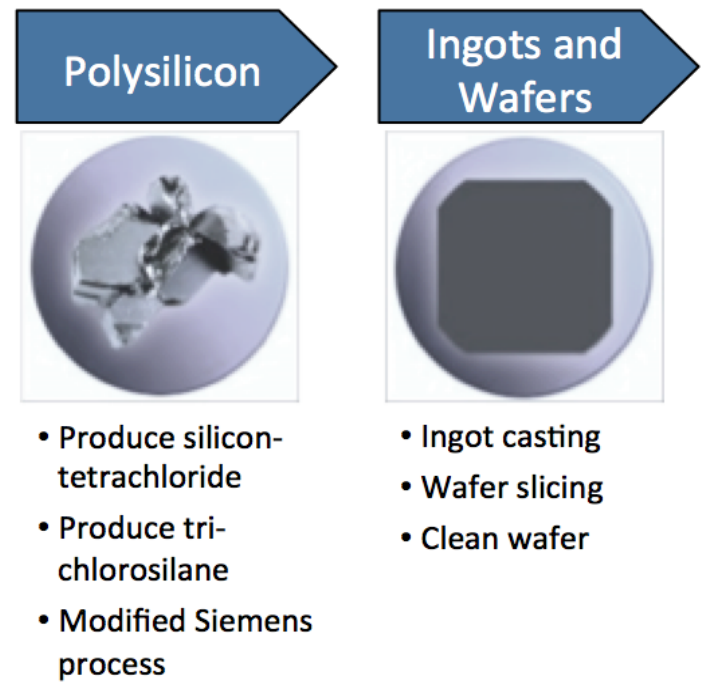

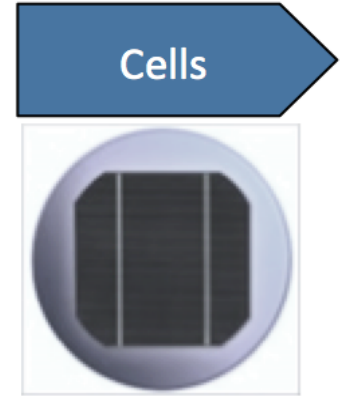

- Etch wafer

- Antireflection coating/ passivation

- Metallization front/back

- Cell testing and sorting

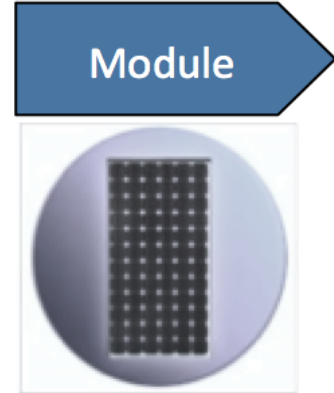

- String cells

- Module layup

- Module lamination

- Module cure/trim

- Frame module

- Module power/ safety testing

Figure 4 - Process steps for mc-Si module production adopted from Navigant Consulting Inc., 2012.

To make mg-Si, lumpy quartz $\left(\mathrm{SiO}_{2}\right)$ and carbon materials are submerged in an electric arc furnace. Through a carbothermic reduction, mg-Si is produced (Jungbluth et al., 2010; Labouret \& Villoz, 2010; Ceccaroli \& Lohne, 2011). The carbon materials consist of metallurgical grade coal as well as woodchips, charcoal and coke (Stoppato, 2008). The coal is washed to remove the ash containing unsuitable impurities (Ceccaroli \& Lohne, 2011). The quality and reactivity of the quartz and carbon are important factors to ensure high material yield and product quality.

The material mix is heated in an arc electric furnace to temperatures of $1500-2000{ }^{\circ} \mathrm{C}$ (Stoppato, 2008). Through a reaction with the carbon, $\mathrm{SiO}_{2}$ is reduced to liquid mg-Si and the mix material creates carbon monoxide (CO) as a co-product, which is further oxidized to 
carbon dioxide $\left(\mathrm{CO}_{2}\right)$ (Ceccaroli \& Lohne, 2011). The liquid mg-Si is tapped from the bottom of the furnace, while the $\mathrm{CO}_{2}$ is released into the atmosphere from the open furnace (Eq. 1).

$$
\mathrm{SiO}_{2}+2 \mathrm{C} \rightarrow \mathrm{mg}-\mathrm{Si}+2 \mathrm{CO}
$$

\section{Purified Crystalline Silicon}

Solar cells use high purity silicon sometimes referred to as solar grade silicon (sog-Si). It has a purity of approximately 99.9999 percent or $6 \mathrm{~N}$ for the 6 nines, whereas silicon used in microprocessors has purity closer to $9 \mathrm{~N}$. The modified Siemens process is most commonly used to produce sog-Si (Jungbluth et al., 2010).

In a controlled atmosphere, such as a crucible, $\mathrm{mg}$-Si is treated in its liquid state. It is easier to remove impurities from the mg-Si when it is in a molten state (Ceccaroli \& Lohne, 2011). The mg-Si is reacted with silicon tetrachloride $\left(\mathrm{SiCl}_{4}\right)$ and hydrogen to produce

trichlorosilane $\left(\mathrm{SiHCl}_{3}\right)$ (Eq. 2). The trichlorosilane goes into a reduction furnace for purification. Under high heat, the trichlorosilane produces sog-Si, silicon tetrachloride and hydrogen chloride (Eq. 3) (Khattak, Joyce, \& Schmid, 2001; Chen, Hong, Yuan, \& Liu, 2016).

$$
\begin{aligned}
& m g-\mathrm{Si}+2 \mathrm{SiCl}_{4}+2 \mathrm{H}_{2} \rightarrow 4 \mathrm{SiHCl}_{3} \\
& 2 \mathrm{SiHCl}_{3} \rightarrow \mathrm{sog}-\mathrm{Si}+\mathrm{SiCl}_{4}+2 \mathrm{HCl}
\end{aligned}
$$

The impurities and by-products are separated from the sog-Si in a slag. Slag can either float on the surface of the molten silicon or sink to the bottom of the crucible, both of which can be easily removed. This process is a closed system and by-products can be recycled for use again (Chen, et al., 2016).

The refined sog-Si melt is poured from the crucible into cast iron molds or onto a bed of silicon fines (Ceccaroli \& Lohne, 2011). The method for solidification helps to determine the size of crystals and distribution of any remaining impurities, which will concentrate at the edges of crystals, forming grain boundaries (Labouret \& Villoz, 2010). This creates the crystalline clusters observed in mc-Si. Figure 5 shows the overall schematic for transforming mg-Si into sog-Si using the modified Siemens process. 


\section{Ingot Casting and Wafer Slicing}

The refined sog-Si melt is poured into cast iron molds or onto a bed of silicon fines (Ceccaroli \& Lohne, 2011). A common method for transforming sog-Si into ingots is directional solidification. Directional solidification is the cooling and solidifying from thin sections to heavy section with a constant metal feed into heavy section to produce casts free of shrinkage defects (Chen, et al., 2016). The method for solidification is important in determining size of crystals and distribution of any remaining impurities that contribute to the growth of grain boundaries in mc-Si (Labouret \& Villoz, 2010). Figure 5 shows the overall schematic for transforming mg-Si into sog-Si ingots using the modified Siemens process.

Thin wafers, between 200 and $500 \mu \mathrm{m}$, are cut from silicon ingots using band saws or wire sawing. An abrasive slurry containing silicon carbide is used during cutting (Labouret \& Villoz, 2010). All silicon scrap generated during wafer production is recycled and reused after washing (Chen et al., 2016).

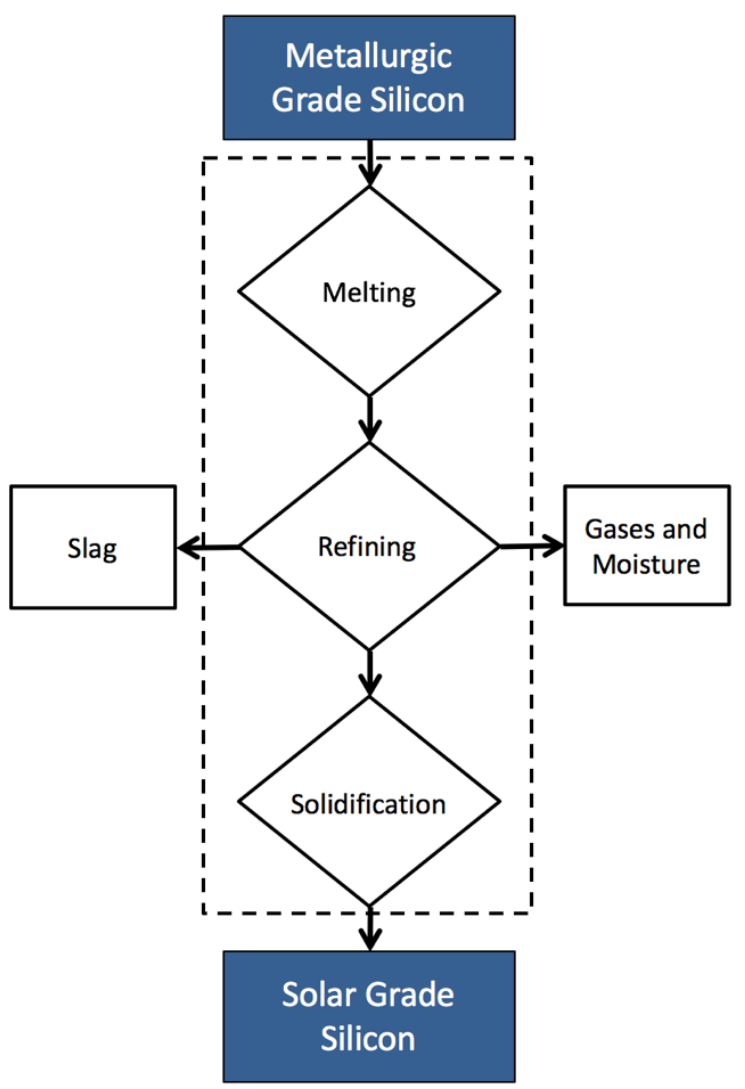

Figure 5 - A schematic approach for purifying mg-Si into sog-Si using a modified Siemens process (Khattak, Joyce, \& Schmid, 2001). 


\subsubsection{Solar Cell Production}

Silicon wafers are processed so that they can take advantage of the photovoltaic effect. The first phase of cell production is texturing with nitric and hydrofluoric acids to remove surface damages and to reduce solar radiation reflectivity of the wafer surface (Chen et al., 2016). Multiple chemical washes are used to process the wafer into a cell: alkali washing, hydrochloric acid wash, hydrofluoric acid wash, and nitrate washing (Labouret \& Villoz, 2010). The front surface of the wafer is polished using a lapping machine. To create a p-n junction for the electric field, phosphorus is doped on the surface at high temperatures $\left(>800^{\circ} \mathrm{C}\right.$ ) to create the n-film (Jungbluth et al., 2010; Chen et al., 2016). The wafers are coated to have a negative-conducting film on the surface. Metal contact material is printed onto the front and backside of the wafer for electrical connection. An anti-reflection coating is applied to the front side of the wafer to help with light absorption and improve overall efficiency. The wafer is finally transformed into a cell. The finished cell is checked and tested for efficiency and other visual characteristics, and classified accordingly (Jungbluth et al., 2010; Labouret \& Villoz, 2010).

\subsubsection{Module Assembly}

A single solar cell is capable of generating around $0.6 \mathrm{~V}$ of power for mc-Si technology (Labouret \& Villoz, 2010). For larger electrical demands, several cells are connected in series to produce more usable amounts of voltage (Frankl et al., 2005). Typically, 60-72 multicrystalline cells will be connected to a panel. Panels are laminated to protect the fragile cells from climatic changes, such as humidity and temperature variation that could cause corrosive damages (Labouret \& Villoz, 2010). When cells are connected to a panel and laminated, the whole system is referred to as a module.

The manufacturing process for production of functional modules is described according to literature with additional information provided by Canadian Solar as part of the case study (Stoppato, 2008; Jungbluth et al., 2010; Labouret \& Villoz, 2010; Environment Canada, 2012). Sheets of glass and ethylene vinyl acetate (EVA) are cut to size and placed onto the beginning of the production line. The glass and EVA sheet will make up the upper surface of the panel, which will be a transparent and resistant surface used to capture light. Solar cells are arranged into a matrix on the glass surface. Soldering techniques are used to connect cells 
with copper alloy connections. The matrix is encapsulated by a second EVA layer and then covered with a backsheet, creating a sandwich of glass/EVA/interconnected cells/EVA/glass (Figure 6). The module is then heated to $100-120{ }^{\circ} \mathrm{C}$ for adhesion and then cooled for solidification of the EVA material (Labouret \& Villoz, 2010). Excess material is trimmed from the edges and connections are insulated. The panel gets an aluminum frame and is sealed to prevent moisture and corrosion of the cells. A junction box is fitted to the frame to connect the panel with devices compatible with its electrical outputs (Jungbluth et al., 2010). Finally, the module is flash tested for power output and luminescence tested for micro cracks for quality assurance (Labouret \& Villoz, 2010). Once the panel passes inspection it will be packed and sorted onto pallets for consumer use.

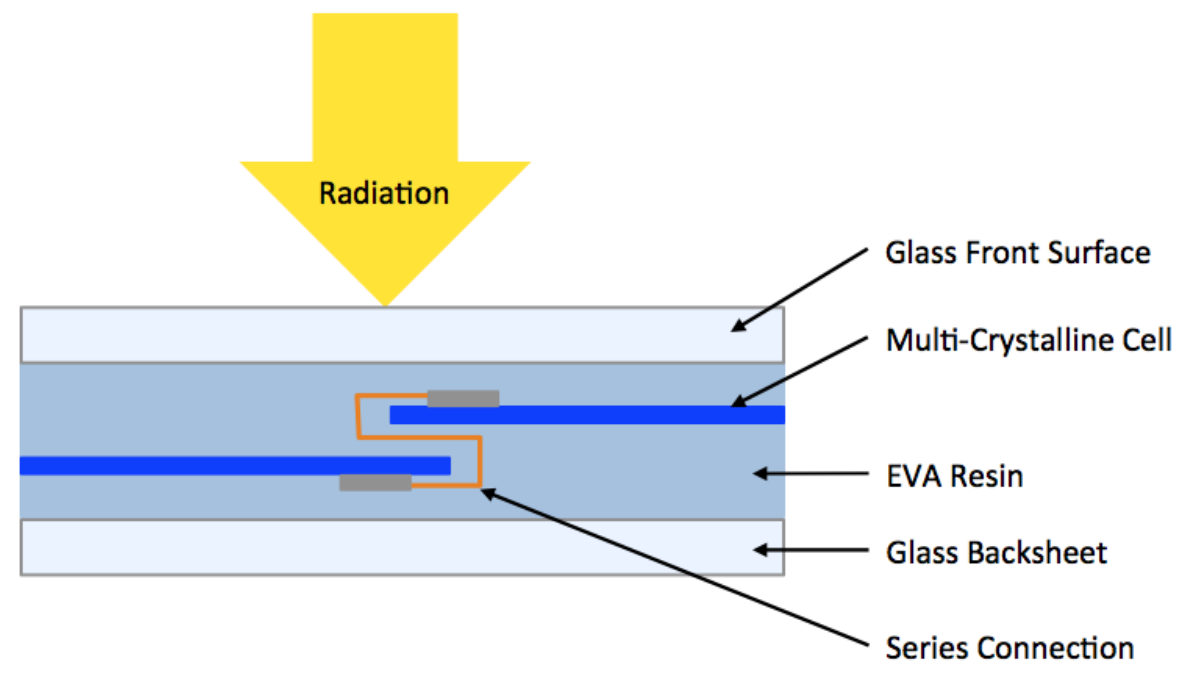

Figure 6 - A cross section illustration of a mc-Si module.

\subsection{Global PV Supply Chain}

The PV supply chain includes the components needed to build solar cells and modules, as well as the services needed to support the development and installation of projects. The equipment or products and services needed to produce a PV system are shown in Figure 7. The upstream portion of the supply chain is comprised of products such as modules, inverters, racking/mounting, and wiring/cable. Alternatively, the downstream describes services that assist with product distribution, project development, engineering, 
procurement and construction (EPC) services, and operation and maintenance (O\&M) services (Navigant Consulting Inc., 2012; Shukla \& Mali, 2015).

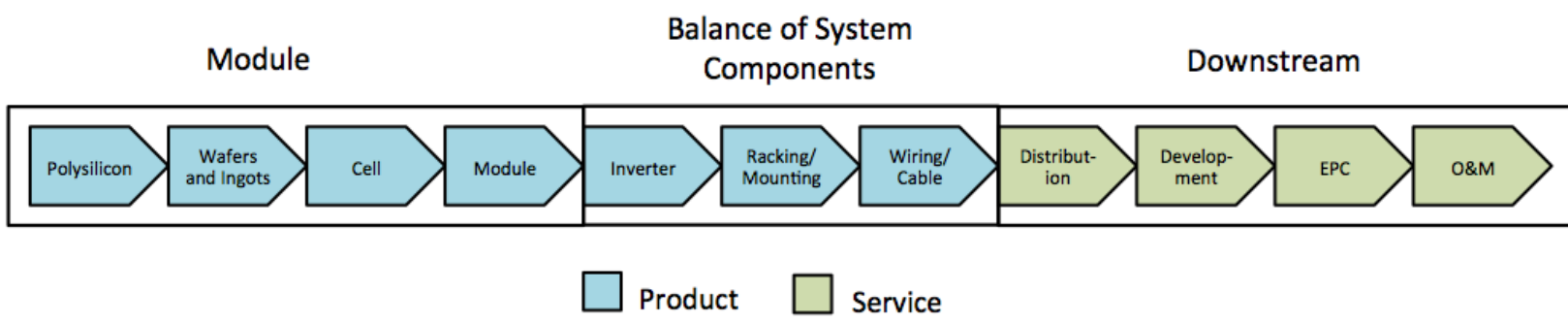

Important support functions for the supply chain include capital equipment and consumables for manufacturing PV components (Navigant Consulting Inc., 2012). For PV

Figure 7 - The PV supply chain (Navigant Inc., 2012).

module assembly, consumables include glass, encapsulents, backsheets and aluminum framing. Services such as software and monitoring, testing, and training/education are used to support industry.

\section{Manufacturing in China}

Prior to 1978, China operated with a high degree of insulation from the international economy; however, following economic reforms it has become a hub for global manufacturing (Bowles \& Dong, 1999). Through the development of "open door" policies, China would integrate itself into the global economy. China became a site for the processing of raw material and semi-finished goods and the re-exporting of finished goods. Dominant exports include labour intensive manufactured goods.

For solar PV products, the majority of supply chain activities occur in China since the necessary facilities to manufacture silicon materials and intermediate components are already sited in China (Frischknecht et al., 2015). Moreover, the labour force in China is abundant and cheap, such that workers are underpaid and not given fair social insurance (Chan \& Zhai, 2013). Due to lower material and labour costs, China has become the world's largest exporter of solar goods (Fu, Liu \& Yuan, 2015).

Environmental concerns surrounding the energy demands for solar PV manufacturing are prevalent in China given their electricity mix, which is still reliant on coal (Stylos \& Koroneos, 2014). The production processes for solar PV modules are energy intensive and alternative 
supply chain options could be used to help reduce the release of pollution and waste. This research is focused on the environmental impacts associated to solar PV manufacturing and will compare the Chinese supply chain to an Ontario-based supply chain. Since Ontario has a relatively cleaner electricity mix, it is speculated that an Ontario supply chain can be used to minimize the environmental impacts for solar technology in terms of embedded energy and emission levels.

\subsection{PV Solar in Ontario}

Currently, Canada has a population of approximately 36 million and it is expected to grow to 44 million by 2050 (United Nations, 2015). Ontario is the most highly populated province in Canada, at 13.8 million, and will see the most impact from growing population changes (Statistics Canada, 2015).

The solar resource potential of Canada is in the moderate range of 800 to about 1300 kilowatt-hours $(\mathrm{kWh})$ generated per kilowatt $(\mathrm{kW})$ of PV installed (NRCan, 2013). The Prairie Provinces have the highest potential, yielding of $1100-1400 \mathrm{kWh} / \mathrm{kW}$ per year (Rosenbloom \& Meadowcroft, 2014). Second to that is Ontario with the potential to generate approximately 1000-1300 kWh/kW annually (Figure 8). Since major energy consumption occurs in urban centers, it is more ideal to develop solar energy in and around cities (Rosenbloom \& Meadowcroft, 2014). The higher population density in cities helps to reduce costs and energy losses from long distance transmission lines. With this in mind, the development of solar energy as a renewable energy option is advantageous for Ontario.

Ontario's use of PV-focused procurement programs (FIT and microFIT) has led to significant solar technology investments within the province. The provincial government's Green Energy and Green Economy Act, 2009 (GEA) was developed to create important changes for renewable energy development in Ontario (Ministry of Energy, 2013). A key objective of the GEA was to create investment in Ontario-based manufacturing of renewable energy equipment. One important policy action required a domestic content provision within the microFIT and FIT program (Table 1). The requirement of domestic content helped to support the solar industry in Ontario by forcing solar installers to buy a portion of equipment from local manufacturers. For microFIT and FIT contracts, designated activities each had specified 
qualifying percentages that contributed to meeting the domestic content requirements as shown in Table 1 (Navigant Consulting Inc., 2012). On May 24, 2013, domestic content requirements were adjusted to satisfy a ruling from the World Trade Organization. Domestic content levels were lowered to $22 \%$ for FIT programs and removed completely for microFIT programs (IESO, 2014).

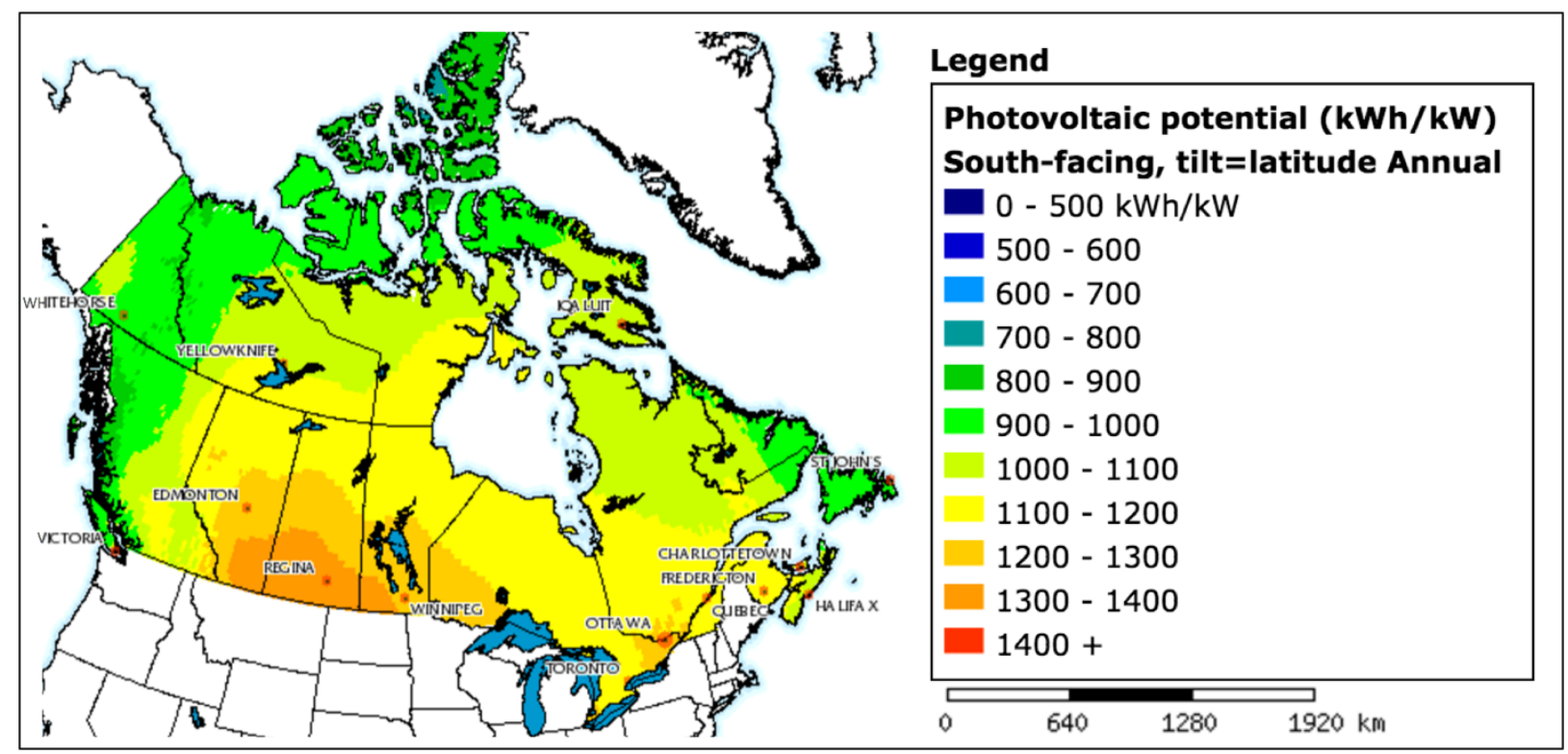

Figure 8 - Annual PV potential (kWh/kW) for Canada developed by the Canadian Forest Service in collaboration with CanmetENERGY Photovoltaic systems group (NRCan, 2013).

Table 1 - MicroFIT and FIT domestic activities and associated qualifying percentages (Navigant Consulting Inc., 2012).

\begin{tabular}{lcc} 
& \multicolumn{2}{c}{ Qualifying Percentages } \\
\cline { 2 - 3 } Designated Activity & $\begin{array}{c}\text { microFIT } \\
\leq 10 \mathrm{~kW}\end{array}$ & $\begin{array}{c}\mathrm{FIT} \\
>10 \mathrm{~kW}\end{array}$ \\
\hline Silicon & $10 \%$ & $11 \%$ \\
Ingots/Wafer & $12 \%$ & $13 \%$ \\
Cells & $10 \%$ & $11 \%$ \\
Module & $13 \%$ & $15 \%$ \\
Inverter & $9 \%$ & $8 \%$ \\
Racking & $9 \%$ & $11 \%$ \\
Wiring and Electrical Housing & $10 \%$ & $9 \%$ \\
On- and Off-Site Labour & $27 \%$ & $18 \%$ \\
Consulting Services & - & $4 \%$ \\
\hline Total & $100 \%$ & $100 \%$ \\
\hline
\end{tabular}


Other initiatives for clean energy development included Ontario's Long Term Energy Plan (LTEP) that provided the Ontario Power Authority (OPA), now combined with the Independent Electricity System Operator (IESO), with policy guidance on the amount and timing of different generations sources to better balance future energy supply and demand (Navigant Consulting Inc., 2012; Ministry of Energy, 2013). Nuclear generation, which was responsible for more than half of the energy supply in 2014, will continue to be the backbone of Ontario's supply; however, more investments are being made into new renewable generation (IESO, 2015). Targets for wind, solar, bioenergy, and hydroelectricity are being reviewed and it is anticipated that renewables, excluding hydro, will be expanded to represent about 46 percent of Ontario's installed capacity by 2025 (Ministry of Energy, 2013).

The growing potential of solar energy combined with solar-focused policies spurred investment in Ontario based manufacturing for solar technology. Solar companies invested in new facilities or contracted manufacturing arrangements in Ontario to meet the domestic content requirements of GEA, which helped to increase renewable energy related employment (Navigant Consulting Inc., 2012).

By 2015, the installed capacity of PV systems in Canada was 1.9GW with 633 MW installed within the past year (IEA, 2015). Installations are mainly concentrated in Ontario and driven mostly by the FIT program (Environment Canada, 2012). Installations in the province continue to grow as solar PV systems become more affordable. From 2005 to 2012, module prices dropped from CAD $\$ 4.31$ to CAD $\$ 1.15$, with the largest costs becoming associated to hardware such as inverters, rather than cells (Poissant \& Bateman, 2014; Rosenbloom \& Meadowcroft, 2014). Solar energy is forecasted to contribute by $8 \%$ to Ontario's energy mix by 2025 as the role of renewables continues to grow (Ministry of Energy, 2013).

\subsubsection{Manufacturing}

\section{Polysilicon Production}

The first unit process of the PV supply chain is the production of polysilicon. This process requires chemical reaction and intense energy demands. In all of Canada, there is only one company based out of Vaughan, Ontario that produces polysilicon - 6N Silicon (Table 2) 
(Navigant Consulting Inc., 2012). They are owned by Silicor Materials, headquartered out of California. 6N Silicon provides a reliable solar silicon feedstock for wafer and cell processing (Silicor Materials, 2012). The silicon feedstock is sold and shipped globally to wafer, cell and module producers; there are no wafer or cell manufacturers in Canada.

Table 2 - Manufacturer profile for 6N Silicon (Navigant Consulting Inc., 2012; Silicor Materials, 2012).

\begin{tabular}{ll}
\hline \multicolumn{2}{c}{ 6N Silicon } \\
\hline Parent Company & Silicor Materials Inc. \\
\hline Canadian-made PV Products & $\bullet$ PV feedstock \\
& $\bullet$ Solar grade silicon \\
\hline Canadian HQ Location & Vaughan, Ontario \\
\hline
\end{tabular}

\section{Module Assembly}

For module assembly, Canadian based manufacturers will source their solar cells from foreign companies, typically based out of China and Taiwan (Navigant Consulting Inc., 2012). These cells are connected electronically and laminated into modules. There are seven companies in Canada who produce PV modules, all with facilities located in Ontario. Many of these companies are contract manufacturers for other multi-national companies; however, five are Canadian companies. Canadian Solar is the largest Canadian company; it is one of the top five global module producers with a global market share of 7\% in 2014 (Poissant \& Bateman, 2014).

Canadian Solar Inc. is a global energy provider dealing in the manufacturing of solar PV modules and the delivery of solar energy solutions (Table 3) (Canadian Solar Inc., 2015). They own multiple production facilities equipped to manufacture silicon, wafers/solar cells and solar PV modules. A large number of their plants are located overseas, mostly in China; they have two crystalline silicon PV module manufacturing facilities in Guelph and London, Ontario. Canadian Solar Inc. in Ontario employs approximately 600 workers and had a maximum total annual production of 432 MW in 2014 (Poissant \& Bateman, 2014). Their Ontario manufacturing has a capacity to manufacture up to $500 \mathrm{MW}$ per year (Canadian Solar Inc., 2015). 
Table 3 - Manufacturer profile for Canadian Solar Solutions Inc. (Navigant Consulting Inc., 2012; Canadian Solar Inc., 2015).

\begin{tabular}{ll}
\hline \multicolumn{1}{c}{ Canadian Solar Solutions Inc. } \\
\hline Parent Company Description & $\begin{array}{l}\text { Division of Canadian Solar } \\
\text { Inc. } \\
\text { ・ Vertically integrated module } \\
\text { manufacturer }\end{array}$ \\
\hline Canadian-made PV Products & $\bullet$ Module assembly \\
\hline Service PV lines of business & $\begin{array}{l}\text { Project development of utility } \\
\text { scale solar farms }\end{array}$ \\
\hline Global/Canadian HQ Location & O\&M \\
\hline Canadian PV Revenues for 2011 & GPC \\
\hline Canadian PV R\&D Expenditures for 2011 & $>\$ 100$ million \\
\hline Canadian-based PV Employees & None \\
(as of Dec. 31, 2014) & 600 \\
\hline$\%$ of Sales for Export & $25 \%$ \\
\hline
\end{tabular}

\subsubsection{Importing}

China is Canada's second largest merchandise export and import partner. The main import commodities from China include electrical and electronic machinery, mechanical machinery, furniture, and toys and sporting equipment (Foreign Affairs, Trade and Development Canada, 2016). Solar PV modules and all their components, including crystalline cells are an example of electrical goods imported from China.

On October 1, 2014, four Ontario-based solar panel companies (Heliene, Eclipsall, Silfab Solar and Solgate) filed a complaint against competing Chinese imports. The claim stated that import panels were threatening the domestic industry. The Canadian Border Service Agency (CBSA) launched an investigation and determined that cheap subsidized PV modules and laminates originating from China were being dumped into Canada (CBSA, 2015). Import PV systems were being sold to importers in Canada at prices lower than the selling price of comparable systems within the export country of China. During their period of investigation, the CBSA found that $100 \%$ of subject goods being imported into Canada had been dumped at a weighted average margin of $124.4 \%$, expressed as a percentage of the export price (CBSA, 2015). The margin of dumping is calculated by subtracting the weighted average export price from the weighted average normal value of goods (CBSA, 2015). Moreover, the 
imported solar modules are also benefiting from subsidies in the form of loans, grants and tax incentives. The dumping and subsidizing of PV module imports was argued as creating unfair competition and threatening to hurt the domestic industry. In response, Canada has approved duties on imported Chinese solar equipment to offset the price advantage caused by dumping. The provisional duties range from $9 \%$ to $202 \%$ for nine specific Chinese exporters, and a duty of $286 \%$ for all other Chinese exporters (Table 4 ).

Table 4 - Estimated margins of dumping, estimated amount of subsidy, and provisional duties by exporter (CBSA, 2015).

\begin{tabular}{|c|c|c|c|}
\hline Exporter & $\begin{array}{l}\text { Estimated Margin } \\
\text { of Dumping* }\end{array}$ & $\begin{array}{l}\text { Estimated } \\
\text { Amount of } \\
\text { Subsidy* }\end{array}$ & $\begin{array}{c}\text { Provisional } \\
\text { Duty Payable* }\end{array}$ \\
\hline $\begin{array}{l}\text { Canadian Solar Manufacturing (Changshu) Inc. } \\
\text { / Canadian Solar International Limited }\end{array}$ & $90.1 \%$ & $84.1 \%$ & $174.2 \%$ \\
\hline Changzhou Trina Solar Energy Co., Ltd. & $125.7 \%$ & $0.8 \%$ & $126.5 \%$ \\
\hline Hanwha SolarOne (Qidong) Co., Ltd. & $103.0 \%$ & $0.3 \%$ & $103.3 \%$ \\
\hline Hefei JA Solar Technology Co., Ltd. & $47.5 \%$ & $3.1 \%$ & $50.6 \%$ \\
\hline Jinko Solar Co., Ltd. & $110.7 \%$ & $1.1 \%$ & $111.8 \%$ \\
\hline Renesola Jiangsu Ltd. & $9.1 \%$ & $0.04 \%$ & $9.14 \%$ \\
\hline Wuxi Taichen Machinery \& Equipment Co., Ltd. & $25.9 \%$ & $1.8 \%$ & $27.7 \%$ \\
\hline Wuxi Suntech Power Co., Ltd. & $202.0 \%$ & $0.5 \%$ & $202.5 \%$ \\
\hline Zhejang Jinko Solar Co., Ltd. & $114.2 \%$ & $1.7 \%$ & $115.9 \%$ \\
\hline All other exporters & $202.0 \%$ & $84.1 \%$ & $286.1 \%$ \\
\hline
\end{tabular}

${ }^{*}$ as a percent of export price

In the case of Canadian Solar products, the CS6X-P module is dumped into Canada at an estimated margin of $90.1 \%$, while already receiving a subsidy of $84.1 \%$. For example, Canadian Solar may be selling in their domestic market at $\$ 1$ per watt but then dumping in Canada at $\$ 0.09$ per watt even though with subsidies already bringing costs down to $\$ 0.16$ per watt. With the new import duties in place, Canadian Solar would experience a duty of $174.2 \%$ and thereby raising prices to $\$ 1.74$ per watt to help Canadian industry avoid material injury.

While these duties are supportive towards Canadian PV module manufacturers by leveling the playing field and allowing them to better compete against foreign markets, there is concern for companies who install Chinese-made solar panels. The costs of solar projects have the potential to increase dramatically with these new duties. Moreover, there are fears that these stricter import duties may slow down enthusiasm for solar power and the overall shift towards renewable energy. 


\subsubsection{Developing an Ontario-based Supply Chain}

The current role of Ontario companies involved in the solar PV life cycle is mainly module assembly. Ontario solar panel makers have a reputation for producing high quality and efficient solar panels in automated facilities. The introduction of import tariffs is helping to make Ontario companies more competitive with their Chinese counterparts.

This research will expand the role of Ontario companies in solar panel manufacturing to develop an Ontario-based supply chain for solar PV technology. Cleaner energy in Ontario has the potential to reduce total emissions and produce a more environmentally benign solar product. Import tariffs increase the cost of Chinese solar panels but could make Ontario solar panels more economically comparable. Using a life cycle assessment approach, the environmental and economical pros/cons for different supply chain scenarios will be compared to evaluate the potential growth of the solar industry in Ontario.

\subsection{Literature Review}

\subsection{The Role of PVs in Sustainable Development}

Solar energy is considered as a sustainable alternative solution to conventional fossil fuels and their associated energy and resource problems. The main arguments (Tsoutsos, Franzeskaki, \& Gekas, 2005; Labouret \& Villoz, 2010; Arvizu et al., 2011; IPCC, 2011; Dubey et al., 2013) for the development of solar PV energy as a renewable resource are discussed below.

I. Solar PV energy development can contribute to social and economic development. The use of PV technology is not limited to the grid, it can be used both in centralized and decentralized systems. It can offer modern energy services to improve living standards in remote and poor rural areas that lack centralized energy access. Furthermore, it can have a positive impact on job creation through manufacturing, installation and maintenance.

II. Using the sun as an energy resource can contribute to a more secure energy supply. The sun is the primary source of energy present on earth; the 
amount of irradiation reaching the earth is sufficient to meet all energy needs. Current PV modules are easy to install and maintain with a life expectancy of 20-30 years but have low energy conversion efficiency compared to conventional fossil fuel energy sources. However, it is expected that with future technological advancements, the reliability of solar PV technology will continue to improve to create greater energy security.

III. Solar PV energy is a clean technology, emitting no GHGs, thus helping to mitigate the effects of climate change. While life cycle assessments (LCA) do indicate a carbon footprint related to the manufacturing of PV technology, the emissions are still significantly lower than those associated with fossil fuel options.

IV. Solar PV energy has reduced negative environmental and health impacts. PV technology is non-combustion based; as a result, it has minimal effects on air and noise pollution. The silicon-based PV technology minimizes the use of toxic waste and has low fatality rates in terms of manufacturing compared to conventional nonrenewable resources.

While the argument for wide scale deployment of solar energy systems seems to have many benefits, there are potential negative environmental impacts that should also be addressed (Tsoutsos et al., 2005; Labouret \& Villoz, 2010; Arvizu et al., 2011).

I. The potential negative impact on land use related to the manufacturing and installation of PV modules for electricity. PV modules are 1-2 $\mathrm{m}^{2}$ in size and installed in large arrays causing potential issues of land cover. Furthermore, there are concerns of landscape modifications related to construction and transport movements.

II. The production of PV technology is considered very energy intensive and large bulk materials are required, such as silicon. Also, small quantities of scarce and toxic material are used in PV technology with the potential for accidental discharge. 
III. The process for waste and disposal of PV modules is unclear. The recycling of PV modules is too small to economically develop module-recycling schemes.

\subsection{Global Status of PV Market}

Polysilicon production is produced globally but the highest share of production is in China at more than $60 \%$ of the world market (Frischknecht et al., 2015; Chen et al., 2016). A share of almost $80 \%$ of the world's production for wafers, cells and modules is produced in China with Europe, Asia and Pacific, and the Americas producing the remainder. By the end of 2014, the global cumulative capacity for solar was at $177 \mathrm{GW}$ with over 20 countries using solar PV to cover more than $1 \%$ of their electricity supply. The majority of installations, over $78 \%$ are represent by China, Japan, USA, UK and Germany. Canada has an installed capacity of 633 MW or $0.0001 \%$ of the total electricity production (IEA, 2015).

In a report by the International Energy Agency (IEA), supply volumes and market shares for the different levels of the PV supply chain were derived (Frischknecht et al., 2015). Polysilicon supply volumes and market mixes for wafer production are shown in Table 5. The Americas, Asia and Pacific, and Europe rely on their own polysilicon supply to produce wafers, whereas China has a mixed polysilicon supply to meet demands (Yang, Liu, Yang, \& Ding, 2015). While most of the mix is domestically supplied polysilicon, the remainder corresponds to exported surplus production volumes from other regions (Frischknecht et al., 2015).

Table 6 shows the supply volumes and market mixes of wafers used in cell production. Cell production volumes are largely dominated by China. All wafers used in Chinese cell production are produced domestically. The cell production in Asia and Pacific, and Europe are mainly produced using domestic content ( $>75 \%$ ); however, imported wafers from China are used to meet 100\% demand (Frischknecht, et al., 2015). In the Americas, the wafer feedstock for cell production is only capable of meeting one third of demand; the remaining two thirds are imported from China. 
The PV industry in China produces a supply that meets the demands of the international market, exporting wafers, cells, and modules to other regions. Almost $90 \%$ of all PV modules produced in China is exported abroad (Yang et al., 2015). The PV industry is being led by China on many different levels of the PV supply chain.

Table 5 - Supply volumes and market mixes of polysilicon used in wafer production and wafer production volumes (Frischknecht et al., 2015).

\begin{tabular}{lccccccccc} 
& \multicolumn{2}{c}{ China } & \multicolumn{2}{c}{ Americas } & \multicolumn{2}{c}{$\begin{array}{c}\text { Asia and } \\
\text { Pacific }\end{array}$} & \multicolumn{2}{c}{ Europe } & Total \\
\cline { 2 - 11 } & MW & $\%$ & MW & $\%$ & MW & $\%$ & MW & $\%$ & MW \\
\hline Europe & 2695 & 11.2 & 0 & 0.0 & 0 & 0.0 & 2698 & 100.0 & 5393 \\
$\begin{array}{l}\text { Asia and } \\
\text { Pacific }\end{array}$ & 3591 & 14.9 & 0 & 0.0 & 2761 & 100.0 & 0 & 0.0 & 6352 \\
$\begin{array}{l}\text { Americas } \\
\text { China }\end{array}$ & 5542 & 23.1 & 360 & 100.0 & 0 & 0.0 & 0 & 0.0 & 5902 \\
\hline $\begin{array}{l}\text { Total } \\
\text { Wafer }\end{array}$ & 12194 & 50.8 & 0 & 0.0 & 0 & 0.0 & 0 & 0.0 & 12194 \\
production & 24021 & 100.0 & 360 & 100.0 & 2761 & 100.0 & 2698 & 100.0 & 29840 \\
\hline
\end{tabular}

Table 6 - Supply volumes and market mixes of wafers used in cell production and production volumes of cells (Frischknecht et al., 2015).

\begin{tabular}{lcccccccccc} 
& \multicolumn{2}{c}{ China } & \multicolumn{2}{c}{ Americas } & \multicolumn{2}{c}{ Asia and Pacific } & \multicolumn{2}{c}{ Europe } & \multicolumn{2}{c}{ Total } \\
\cline { 2 - 10 } & MW & $\%$ & MW & $\%$ & MW & $\%$ & MW & $\%$ & MW \\
\hline Europe & 0 & 0.0 & 0 & 0.0 & 0 & 0.0 & 2698 & 88.8 & 2698 \\
$\begin{array}{l}\text { Asia and } \\
\text { Pacific }\end{array}$ & 0 & 0.0 & 0 & 0.0 & 2761 & 73.4 & 0 & 0.0 & 2761 \\
$\begin{array}{l}\text { Americas } \\
\text { China }\end{array}$ & 0 & 0.0 & 360 & 33.8 & 0 & 0.0 & 0 & 0.0 & 360 \\
\hline $\begin{array}{l}\text { Cell } \\
\text { production }\end{array}$ & 22456 & 100.0 & 706 & 66.2 & 999 & 26.6 & 339 & 11.2 & 24500 \\
\hline
\end{tabular}

\subsection{PVs in Ontario}

The FIT and microFIT programs were introduced in 2009 as part of the GEA with one of the objectives being to promote solar PV projects. At its peak, FIT was offering premiums of $\$ 0.802 / \mathrm{kWh}$, creating large consumer demand for solar energy (Branker \& Pearce, 2010). An additional caveat to the program required installation projects to use $60 \%$ made-in- 
Canada components, which spurred the growth of the solar industry in Canada. However, Ontario eventually lost an anti-competition ruling with the World Trade Organization (WTO) and dropped the made-in-Canada requirement down to below 30\% (Lenio, 2014).

Ontario has a large potential for solar electricity, with enough solar radiation to meet almost $60 \%$ of projected peak electricity demand in 2025 (Nguyen \& Pearce, 2010). In a case study by Nguyen and Pearce (2010), they found that southeastern Ontario possessed over 935,000 acres of potential solar farmland, capable of producing 90 GW of PV power. Rooftop PV installations were studied by Wiginton, Nguyen and Pearce (2010). They found that with appropriate rooftop coverage in southeastern Ontario a potential PV peak power output of $5.74 \mathrm{GW}$ or $25.8 \%$ of peak electricity demand could be reached. Rooftop installations do not produce as much power as solar farms; however, when combined these PV technologies possess enormous potential for producing a sustainable source of clean energy.

Demand for solar energy and supportive policies have brought solar manufacturers into Ontario but the number of companies based out of Ontario is a small handful since high taxation and labour costs make it difficult for them to compete with other foreign competitors. Many of the companies located in Ontario are part of large multi-national companies. In a study by Branker and Pearce (2010), different scenarios for provincial and federal funding were considered to support the continued growth of the PV industry. They found two scenarios that would most likely support the success of a $1 \mathrm{GW}$ PV plant with joint investment from both the provincial and federal government: $100 \%$ subsidy of construction and give away to a company, and partial subsidy of construction with a funding program to provide up to $15 \%$ of total eligible costs. It has been suggested that is important to grow the PV industry because it can help stimulate economic growth and job creation. The estimates on job creation for solar PV vary by geography; however, in a report by Pollin and GarretPeltier (2009), solar PV energy has the potential of creating 15.8 jobs per 1 million dollars of spending in Ontario with an estimated wage rate above $\$ 20$ per hour.

Ontario-based manufacturing has a small market share for globally produced PV modules, with China (due mainly to low production costs) dominating at approximately 60\% (Rosenbloom \& Meadowcroft, 2014). However, China currently relies heavily on carbonintensive fossil fuels for electricity generation while Ontario has a relatively low carbon- 
intensive network, including nuclear, hydroelectricity and natural gas; that can be used to leverage the production of environmentally benign PV modules. In general, the growth of the solar industry in Ontario can provide a boost to the economy, provide a reliable energy option for future demands, and promote the production of environmentally responsible solar products.

\subsection{Environmental Management Systems (EMS)}

The Earth's ecosystem has become increasingly dominated by human activity, promoting the perpetual growth in material consumption and population. Industry, politics and society have become more aware of growing environmental problems and potential future impacts. In response, corporations are shifting away from environmental compliance and more towards environmental management that will continuously improve environmental performance (Finkbeiner, Wiedermann, \& Saur, 1998; Delmas, 2001; Nawrocka, Brorson, \& Lindhqvist, 2009; To \& Lee, 2014). Corporate decisions and company policies now take into account technical, economic, social and environmental aspects.

\subsubsection{ISO 14000 Series for Environmental Management}

Following the attention for sustainable development, the International Organization for Standardization (ISO) collaborated with the International Electrotechnical Commission (IEC) to develop the ISO 14000 environmental standards series to promote improved environmental policies and practices. The goal of ISO 14000 is to provide companies with a framework for managing their environmental impacts by establishing an effective environmental management system (EMS) (Rezaee \& Elam, 2000). The series describes a voluntary approach for companies to minimize environmental risk and consists of 21 standards that are divided into six categories: environmental management systems, environmental auditing, environmental labeling, environmental performance evaluation, life cycle assessment, and environmental terms and definitions (Figure 9) (Finkbeiner et al., 1998; Rezaee \& Elam, 2000).

The ISO 14001 was first approved in 1996 and updated in 2000, 2004, and 2015 (To \& Lee, 2014; ISO 14001, 2015). It identifies the key points for the development of an environmental policy; identification of environmental aspects, definition of objectives and targets, 
implementation of a program to attain goals, monitoring and measuring of effectiveness, and the review of management systems for continued improvement (Rondinelli \& Vastag, 2000). In general, ISO 14001 is used by corporations to identify significant environmental aspects and control the environmental impacts of an organization's activities, products or services; allow a systematic approach to setting and achieving environmental objectives and targets as well as demonstrating objectives and targets be achievable; and improve an organization's environmental performance continually (To \& Lee, 2014). The additional standard categories are used as tools to provide additional guidelines to support the design and implementation of an international benchmark for a good EMS (Finkbeiner et al., 1998; Szwilski, 2000).

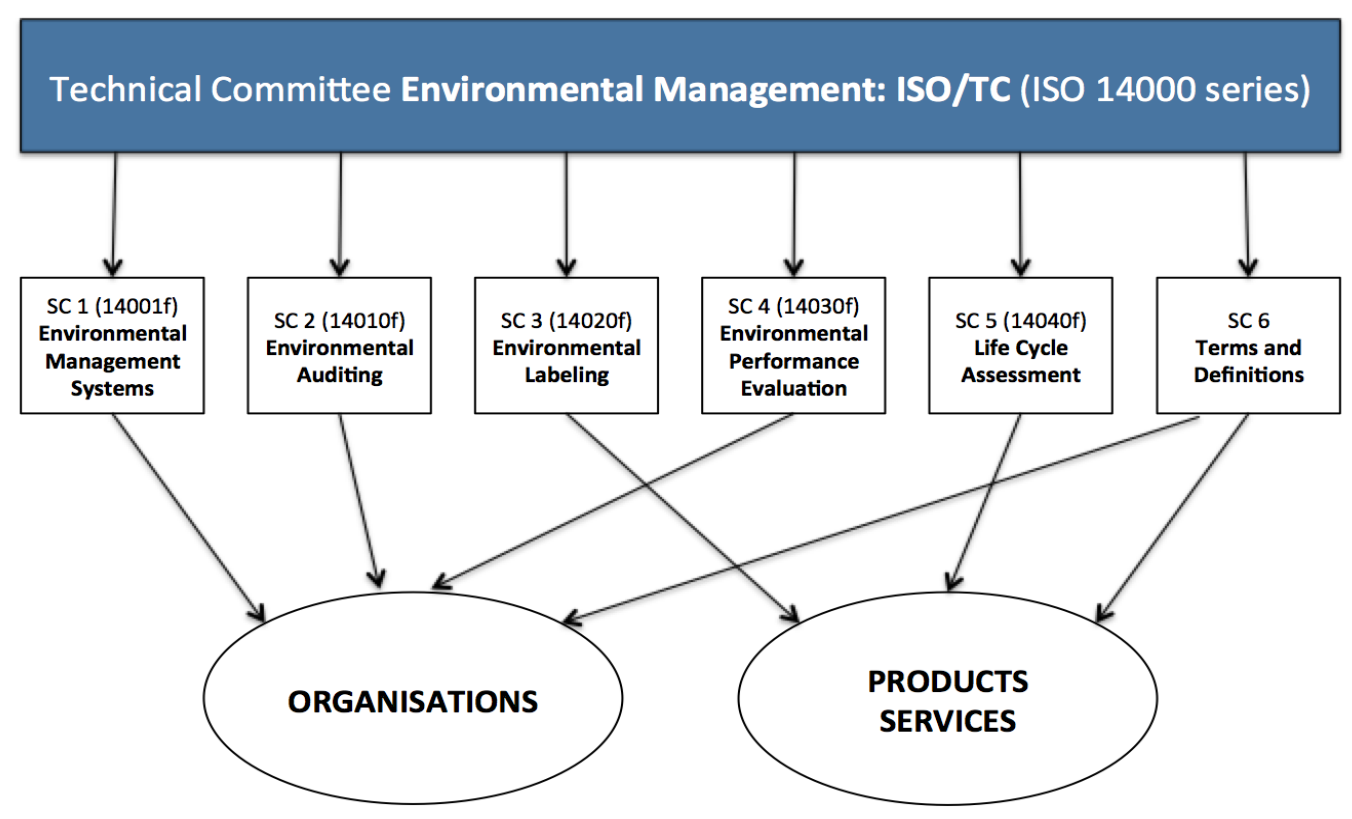

Figure 9 - Environmental management tools for ISO 14000 series (Finkbeiner et al., 1998).

The ISO 14001 was first approved in 1996 and updated in 2000, 2004, and 2015 (To \& Lee, 2014; ISO 14001, 2015). It identifies the key points for the development of an environmental policy; identification of environmental aspects, definition of objectives and targets, implementation of a program to attain goals, monitoring and measuring of effectiveness, and the review of management systems for continued improvement (Rondinelli \& Vastag, 2000). In general, ISO 14001 is used by corporations to identify significant environmental aspects and control the environmental impacts of an organization's activities, products or services; 
allow a systematic approach to setting and achieving environmental objectives and targets as well as demonstrating objectives and targets be achievable; and improve an organization's environmental performance continually (To \& Lee, 2014). The additional standard categories are used as tools to provide additional guidelines to support the design and implementation of an international benchmark for a good EMS (Finkbeiner et al., 1998; Szwilski, 2000).

Certification in ISO 14001 is considered important for effective policy development. However, the opinion on its effectiveness for continuous improvement is still debated. The supporters for certification believe that it creates substantial operational, managerial, and competitive benefits for corporations; the opposing view believes that certification lacks legal compliance and is merely used as an image-boost by corporations (Rondinelli \& Vastag, 2000). Currently, the guidelines for ISO 14001 certification only requires companies to establish systems or structures for monitoring environmental impacts as it is focused only on processes and not outcomes (Delmas, 2001; Szymanski \& Tiwari, 2004). There are no absolute quantitative targets that must be met for certification, so beyond meeting regulations, there is no guarantee for performance improvement and no provisions for decertification (Delmas, 2001; Psomas, Fotopoulos, \& Kafetzopoulos, 2011; Testa, Rizzi, Daddi, \& Gusmerotti, 2014).

Despite these concerns, many studies have been conducted on the positive impacts that ISO 14000 series have had on corporate environmental performance. Although there is nothing legally binding about the ISO standards, they do promote a more responsible attitude towards environmental sustainability. Rondinelli and Vastag (2000) used a case study method to assess the impacts of ISO on Alumax Mt Holly, an aluminum ingot production plant, in South Carolina. Their analysis tracked environmental performance from 1995 to 1998. The results of their study largely showed behavioral changes, which lead to improvements in employee awareness, both in the workplace and at home, operational efficiency and effectiveness (Rondinelli \& Vastag, 2000). In a longer study from 1991 to 2005, Potoski and Prakash (2013) study the effects of ISO 14001 participation on pollution levels for 138 countries. Using statistical analysis, the results showed that for a 1 percent increase in ISO adoption there was an associated reduction in sulfur dioxide $\left(\mathrm{SO}_{2}\right)$ emissions by 0.064 
percent (Potoski \& Prakash, 2013). Similarly, Iwata, Arimura, \& Hibiki (2010) saw positive effects on the levels of toluene emissions for 216 manufacturing facilities operation in Japan in 2002.

Another important performance improvement for EMS is waste indicators. In a study by King, Lenox, \& Terlaak (2005), 7899 manufacturing facilities in the US were sampled and data collected from the Toxic Release Inventory (TRI) showed significant reductions in intensity of toxic releases. Using a sample of 264 manufacturing facilities in the US from 1996 through to 2001, Szymanski and Tiwari (2004) show that ISO adoption can help to reduce toxic emissions; 75 percent of companies in their sample experienced reduction of emissions, 53 percent of those doing so within a year of certification.

With the growing pressures for environmental sustainability and the observed positive impacts of ISO 14001, more companies are seeking certification. The value of ISO 14001 for EMS has become more recognized and more companies are requiring their own suppliers to implement the standard (Nawrocka et al., 2009). On a global scale, To and Lee (2014) found the diffusion of ISO 14001 certification to resemble a logistic growth curve, with the biggest number of new certificates being issued in the Far East followed by Europe and Africa/West Asia.

\subsubsection{ISO 14040 Life Cycle Assessment (LCA)}

The life cycle assessment is a method that corporations use to analyze environmental impacts of their products or services that can assist in the development of an effective EMS. The first examples of LCAs were developed in the 1970s in response to the oil-crises (Klöpffer \& Rippen, 1992; Klöpffer, 2006). In September 1993, "Guidelines for Life-Cycle Assessment; a Code of Practice" was published by the Society of Environmental Toxicology and Chemistry (SETAC) to provide LCA practitioners a technical framework on how to conduct LCA studies (Perriman, 1993; Consoli et al., 1994; Klöpffer, 2006). Following the release of ISO 14001, ISO took leadership for LCAs and published a systematized framework resulting in ISO 14040 standards in 1997 (Marsmann, 2000; Klöpffer, 2012). It has become one of the support tools used by corporations to establish an effective EMS and gain ISO 14001 certification. 
ISO 14040 describes four principal components for conducting LCAs: goal and scope definition, inventory analysis, impact assessment, and improvement assessment (Figure 10) (Klöpffer, 2006; ISO 14040, 2006). The duration of this assessment can span the entire lifecycle of a product or service ("cradle-to-grave"), considering the life stages of raw material extraction, material processing, manufacturing, product use, and waste and disposal (Figure 11) (ISO 14040, 2006; Gerber, 2014). However, LCAs can be applied to a broader range of studies and are not limited to cradle-to-grave. With proper justification an LCA can be adjusted to focus on specific parts of a product's life cycle (Finkbeiner et al., 2005). For example, this research focuses on the partial life cycle for PV technology from resource extraction to the factory gate ("cradle-to-gate") (Figure 11).

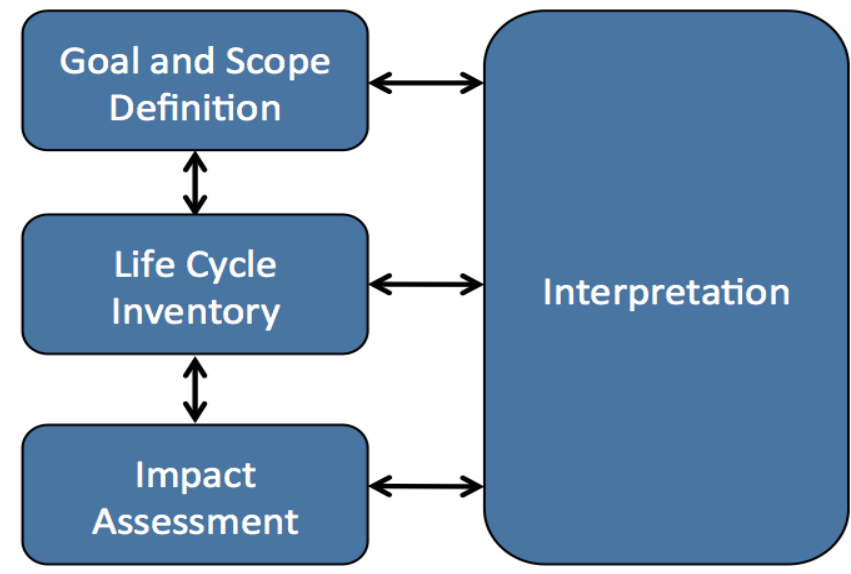

Figure 10 - Stages of an LCA (ISO 14040, 2006).

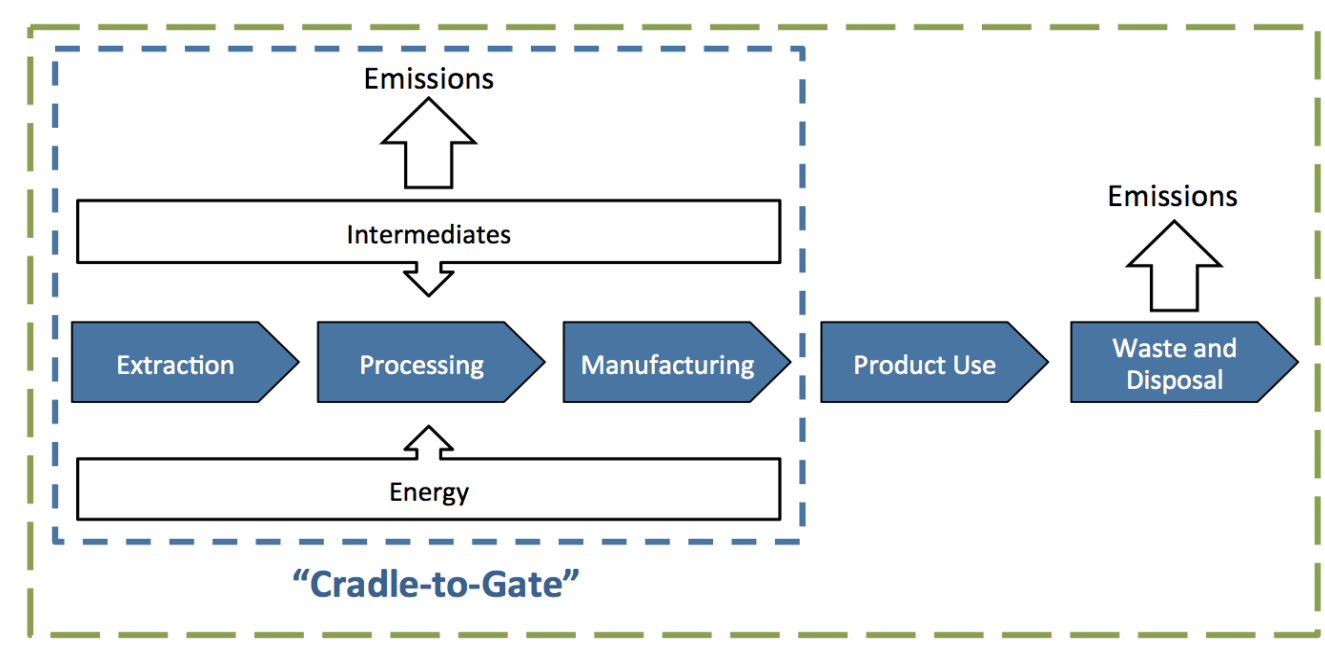

"Cradle-to-Grave"

Figure 11 - The different system boundary types for an LCA (ISO 14040, 2006). 


\subsubsection{EMS for PV Technology}

In the solar PV industry, the LCA method has been used to evaluate environmental impacts and to support improved performance of EMS for ISO 14001 certification. From a cradle-tograve analysis, solar energy using PV technology produces a carbon footprint of 1-218 $\mathrm{g} \mathrm{CO}_{2}$ eq/kWh with deviations up to $200 \mathrm{~g} \mathrm{CO}_{2}$-eq/kWh (de Wild Scholten, 2013; Nugent \& Sovacool, 2014; Wong, Royapoor, \& Chan, 2016). When compared to fossil fuels (coal, oil, and gas), which have an approximate carbon footprint of 469-1001 $\mathrm{g} \mathrm{CO}_{2}$-eq/ $\mathrm{kWh}$, solar energy is more suitable for sustainable development (IPCC, 2011).

Most of the environmental impacts for PV technology arise from the production process that can be highly energy intensive, while PV operation is considered almost absolutely clean. The GHG emission from solar energy is mostly derived from electricity demands during the production phase, approximately $80-90 \%$ of total energy requirements (Wong et al., 2016). The electricity consumed for the module manufacturing process is typically drawn from nonrenewable sources. Additional impacts arise from the hazardous materials and other toxic chemicals such as silane, silica dust and solvents (Chen, Hong, Yuan, \& Liu, 2016).

Fthenakis et al. (2008) performed a cradle-to-gate analysis with production data to evaluate the primary energy demands of PV technology produced in 2004 through to 2006. Their results showed variation in primary energy estimates. In a review by Alsema (2000), multicrystalline technology with an efficiency of $13 \%$ was found to use 2400 to $7600 \mathrm{MJ}$ of energy per $\mathrm{m}^{2}$ of $\mathrm{PV}$ panel area with payback periods of 3 to 4 years assuming an irradiation of $1700 \mathrm{kWh} / \mathrm{m}^{2}$ of annual irradiation. The largest energy estimates were assumed for silicon purification and crystallization. It is typical for LCA studies to be based on old data sets and do not always accurately reflect the current technology status (Alsema \& de Wild Scholten, 2006). The difficulty in performing accurate LCAs of solar PV modules is due to estimates and uncertainties related to data. As a result, data on the environmental impacts of PV module manufacturing is based on secondary data sources (Alsema, 2000; Alsema \& de Wild Scholten, 2006; Pacca, Sivaraman, \& Keoleian, 2006; Nugent \& Sovacool, 2014).

In an attempt to provide a more accurate reflection of current PV technology available on the market, studies have aimed to use more reliable data through collaboration with the manufacturer (Hondo, 2005; Stoppato, 2008; de Wild Scholten, 2013). Hondo (2005) 
performed a case study of Japan and the life cycle GHG emissions from nine different power generation systems, one of those being a PV system. The results of the study suggested that LCA results are easily varied based on assumptions made in regards to the lifetime of PV systems; for a 10-year lifetime, the impact of a PV system was calculated at $136 \mathrm{~g} \mathrm{CO}_{2}$ $\mathrm{eq} / \mathrm{kWh}$ and gradually declined as the lifetime was extended (Hondo, 2005). In a similar study, Stoppato (2008) performed an LCA for solar PVs produced by Kyocera, a Japanese electronics company. From a cradle-to-grave analysis, the calculated impact for the solar PV module with efficiency of $16 \%$ was $50-800 \mathrm{~g} \mathrm{CO}_{2}$-eq/ $\mathrm{kWh}$ with a payback times between 3.4 and 6.5 years; these ranges describe the results for 26 countries (Stoppato, 2008). A more recent study by de Wild-Scholten (2013) performed an LCA using 2011 manufacturer data; the carbon footprint for mc-Si modules of $14 \%$ efficiency was $27.2 \mathrm{~g} \mathrm{CO}_{2}$-eq/kWh and a payback time of 1.4 years given a Chinese electricity mix and irradiation levels of 1700 $\mathrm{kWh} / \mathrm{m}^{2}$ annually. These results show the inconsistency in results due to assumptions made on process parameters, primary energy estimates and geography.

\subsection{The Case Study Method}

The case study method is used to answer questions of "how" or "why". More specifically, it is used when an investigator desires to: define topics broadly and not narrowly, cover contextual conditions and not just a phenomenon of study, and rely on multiple, not singular sources of evidence (Yin, 1993; Yin, 2013). Both qualitative and quantitative methods can be used for case study research. It is important that investigation of a case covers both a particular phenomenon and the context within which the phenomenon occurs; context is important for building theory (Yin, 2013). Understanding context ensures that the case under study is unique but also generalizable (Stake, 1995).

In case study research, the selection of cases should be particular and not general; the investigator should have a deep understanding of their case. Conducting a case study should utilize protocols that contain instruments for research; overview the study project, field procedures, case study questions, and provides a guide for reporting. For data collection, it is important to use multiple sources of evidence; create a case study database; and maintain a chain of evidence (Yin, 2013). How data are gathered and interpreted is driven by the 
research question; the investigator should be careful to consider what needs to be known and what kinds of relationships exist (Stake, 1995).

There are six types of case studies that have been identified through the literature. Table 7 summarizes the different case types. While it can be difficult to sort case studies into these categories, they are useful in understanding the methods that should be used to interpret results. The analysis of case study results should show that: relevant evidence was relied on heavily; that all major rival interpretations were dealt with; that the most significant issues of study were addressed; and that prior expert knowledge was included (Yin, 2013).

Table 7 - "Types" of case study

\begin{tabular}{|c|c|c|}
\hline Author & Type of Case Study & Description \\
\hline \multirow{3}{*}{ Yin (2013) } & Exploratory & $\begin{array}{l}\text { Aimed at defining the questions and hypotheses of a } \\
\text { subsequent study or determining the feasibility of } \\
\text { desired research procedure. Used to explore situations } \\
\text { where phenomena have no clear, single set of } \\
\text { outcomes. }\end{array}$ \\
\hline & Descriptive & $\begin{array}{l}\text { The use of data to presents a complete description of a } \\
\text { phenomenon within its context. Theory is developed to } \\
\text { cover the scope and depth of the case being described. }\end{array}$ \\
\hline & Explanatory & $\begin{array}{l}\text { Data presents a cause-effect relationship - explaining } \\
\text { which causes produced which effects. Used for real-life } \\
\text { phenomena that are too complex for survey or } \\
\text { experimental methods. }\end{array}$ \\
\hline \multirow{3}{*}{ Stake (1995) } & Intrinsic & $\begin{array}{l}\text { There is an intrinsic interest in the case. The purpose is } \\
\text { to learn more about the subject - not to build theory. }\end{array}$ \\
\hline & Instrumental & $\begin{array}{l}\text { Applied when there is need for understanding - } \\
\text { provide insight for a particular case. Used to help refine } \\
\text { a theory. }\end{array}$ \\
\hline & Collective & $\begin{array}{l}\text { The selection of multiple cases, where each case is } \\
\text { instrumental to learning; however, coordination } \\
\text { between individual cases is required. }\end{array}$ \\
\hline
\end{tabular}

The quality of good case study research requires a narrative that deals with the complexities and contradictions of real life in relation to the case. Flyvbjerg (2006) identifies and summarizes these misunderstandings into five topics: theoretical data is more valuable than practical knowledge; generalizations cannot be made on the basis of an individual case, therefore, the case study method cannot contribute to scientific development; the case study 
method is only useful for generating hypotheses and is not suitable for hypotheses testing and theory building; case studies are always bias towards verification; and it is difficult to summarize specific case studies and develop general propositions and theories. Therefore, it is the duty of the researcher to develop a narrative that addresses these concerns so that there are no confusions or misunderstanding.

For this research, the case study will be developed around the manufacturing activities involved in the "cradle-to-gate" life cycle for a CS6X-P module manufactured by Canadian Solar. The type of case can be described as both exploratory and instrumental as it will aim to understand the environmental impacts that occur from manufacturing and assess the feasibility of an Ontario PV supply chain.

\subsection{Research Methods}

\subsection{Case Study: Analysis of a mc-Si PV Module}

This research employs a case study method to analyze the life cycle impacts that arise from manufacturing a mc-Si PV module. There are two scenarios for PV module manufacturing that are studied: the current supply chain with manufacturing based in China, and an idealized supply chain with manufacturing based in Ontario, Canada. Using combined methods of life cycle assessment (LCA) and value chain analysis, the PV module supply chain is studied to identify areas of significant environmental cost. The two case studies are compared to evaluate market differences, both environmentally and economically, to determine how each supply chain impacts the environment. Additionally, the results will be analyzed to indicate the potential for an expanded solar PV supply chain in Ontario

\subsection{Application of Life Cycle Assessment Framework}

The life cycle assessment (LCA) method is used as a tool to examine environmental net gains and consequences related to the manufacturing or use of products or services during its lifetime (Consoli et al., 1994). It is widely used as a standardized tool for environmental assessment and management of environmental systems.

The LCA method in this case calculates the environmental impact for the manufacturing of mc-Si PV modules by considering the material, energy, and emission flows of each unit 
process step. GaBi sustainability software was used to support each stage of the LCA analysis. GaBi has an up-to-date Life Cycle Inventory database and is programmed to calculate performance using a variety of social and environmental impact categories (PE International, 2010). Modelling the supply chain with the LCA approach will identify environmental weak spots. Using relevant indicators of environmental and social performance to compare supply chain scenarios, based on where manufacturing occurs, will also help to provide insight on how to develop sustainable supply chains from both an environmental and economic standpoint.

LCAs are conducted according to ISO 14000 and ISO 14040 standard. The framework for LCAs consist of four steps (ISO 14040, 2006):

1. Goal and scoping

2. Inventory analysis

3. Impact assessment

4. Interpretation

These steps are described in more detail in the following sections.

\subsubsection{Goal and Scoping}

According to ISO standards, the first phase of an LCA is the definition of the goal and scope. The goal of an LCA should state the intended application, reasons for carrying out the study, the intended audience, and how the results will be used (ISO 14040, 2006). Scoping should describe the product system that is to be studied with all assumptions detailed and defined. The following items need to be defined during this stage of the LCA:

- Function of the product

- Functional unit

- System boundary

- Allocation procedures

- Data requirements

- Data quality requirements

- Impact categories and method of impact assessment

- Assumption and limitations 
- Type of critical review, if any

- Reporting type

For this research, the product being studied is the CS6X-P module manufactured by Canadian Solar. It functions by converting sunlight into solar electricity through the photovoltaic effect, as discussed previously in Section 2.2. It is rated to produce 320 watts of power in 1 hour of peak solar intensity under nominal operating conditions, as shown in Table 8. The peak solar intensity for Ontario is averaged to approximately $1150 \mathrm{kWh}$ per year (SolarGIS, 2016).

The annual electricity generation ( $E_{\text {agen }}$ ) for the CS6X-P module would be approximately 368 $\mathrm{kWh}$ per $\mathrm{m}^{2}$ (Eq. 4). For the 25-year lifespan the CS6X-P, there would be a total generation of $9200 \mathrm{kWh}$ (Eq. 5).

$$
\begin{aligned}
& 0.32 \mathrm{~kW} \times 1150 \mathrm{kWh} / \mathrm{m}^{2} \cdot \text { year }=368 \mathrm{kWh} / \mathrm{m}^{2} \cdot \text { year } \\
& 368 \mathrm{kWh} / \mathrm{m}^{2} \cdot \text { year } \times 25 \text { year } / \text { panel }=9200 \mathrm{kWh} / \text { panel }
\end{aligned}
$$

Table 8 - Primary parameters for a CS6X-320P mc-Si PV module under Standard Test Conditions (STC) of irradiance of $1000 \mathrm{~W} / \mathrm{m}^{2}$, spectrum AM 1.5 and cell temperature of $25^{\circ} \mathrm{C}$ (Canadian Solar Inc., 2015).

\begin{tabular}{lc}
\hline Parameter & Value \\
Module size & $1954 \times 982 \times 40 \mathrm{~mm}$ \\
Mass & $22 \mathrm{~kg}$ \\
Frame & Anodized aluminum alloy \\
Front cover & $3.2 \mathrm{~mm}$ tempered glass \\
EVA sheet thickness & $0.5 \mathrm{~mm}$ \\
Wafer thickness & $200 \mu \mathrm{m} \pm 20 \mu \mathrm{m}$ \\
Cell arrangement & $72(6 \times 12)$ \\
Cell area & $156 \times 156 \mathrm{~mm}$ \\
Efficiency of cells & $16.68 \%$ \\
Operation life & 25 years \\
Open circuit voltage & $45.3 \mathrm{~V}$ \\
Optimum operating voltage & $36.8 \mathrm{~V}$ \\
Short-circuit current & $9.26 \mathrm{~A}$ \\
Optimum operating current & $8.69 \mathrm{~A}$ \\
Maximum power & $320 \mathrm{~W}$ \\
Operating temperature & $-40{ }^{\circ} \mathrm{C}$ to $+85^{\circ} \mathrm{C}$ \\
Maximum system voltage & $1000 \mathrm{~V} \mathrm{DC} \mathrm{(IEC)}$ \\
Maximum series fuse rating & $15 \mathrm{~A}$ \\
Power tolerance & $\pm 5 \mathrm{~W}$ \\
\hline
\end{tabular}

The functional unit is the quantified definition of a product's function and is used to provide a reference for all inputs and outputs (ISO 14040, 2006). In this study, the CS6X-P module of 
mc-Si produced using current and consolidated technologies was used to define the functional unit. This referencing is used for quantifying the environmental impacts from manufacturing procedures, rather than environmental impacts from the use of module technologies. Therefore, the system boundaries of this study will exclude the use stage of the product, and only include unit process steps describing raw material extraction, production of intermediates, and the production of the module itself. This represents the "cradle-togate" boundary as identified earlier and will examine the unit steps describing silicon processing through to the production of solar cells and the assembly of the CS6X-P module. Transport will not be included and will be assumed to have almost negligible impacts on a per module basis. Figure 12 shows the system boundary for this research and the unit process steps that will be included in the LCA.

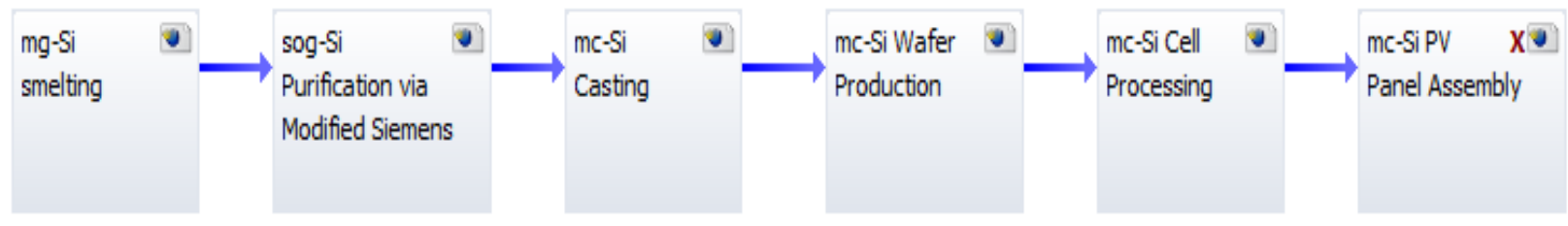

Figure 12 - "Cradle-to-gate" system boundary constructed for a PV module using GaBi sustainability software.

Each of the unit processes will produce more than one product and must be allocated to a relevant product or byproduct (PE International, 2010). Flows for the manufacturing of the CS6X-P module will be allocated either by mass or heating value. Data descriptions will provide clear understanding of how data will be allocated. The quality of the data set will reflect the current status of PV module technology and processes being used. The descriptions of data quality are important for the reliability of the study results and will be helpful for interpretation.

\subsubsection{Life Cycle Inventory}

LCI analysis is an investigation of material and energy consumption and environmental emissions for a given product or service system defined by its life cycle or boundary limits (Frischknecht et al., 2015). Qualitative and quantitative data are collected for every unit process in the system. The data can be classified into 8 categories (ISO 14040, 2006) as shown in Figure 13. 


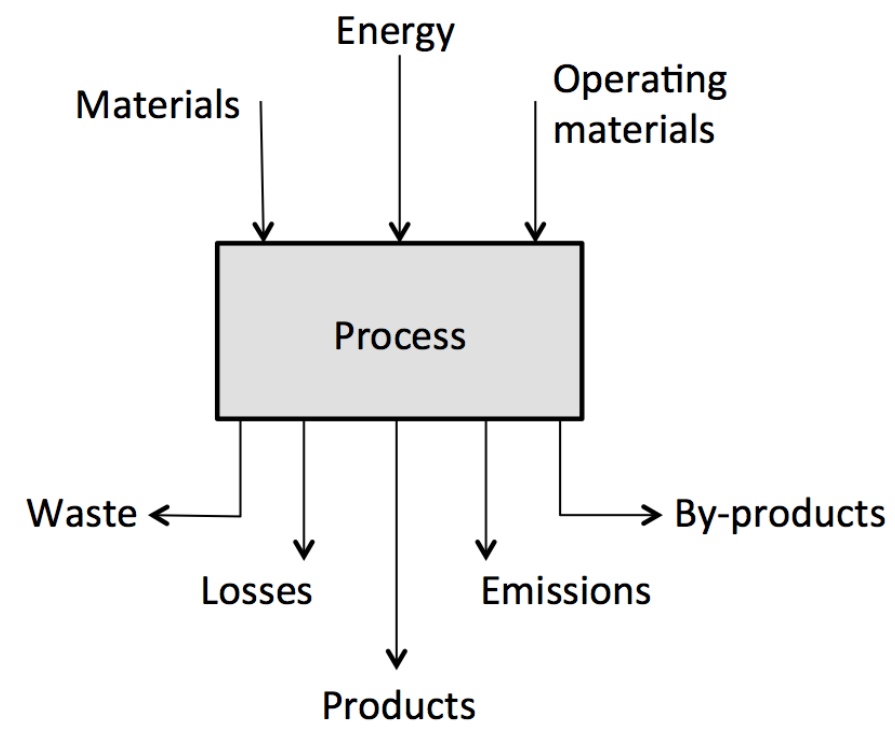

Figure 13 - Classification categories for process data inputs/outputs (ISO 14040, 2006).

The data collection for this study comes from the International Energy Agency (IEA). The IEA is a collaborative group of researchers and experts who serve as an information source on the statistics of energy. The IEA Photovoltaic Power Systems Programme (PVPS) presents the latest inventory data for a wide variety of PV technology, including mc-Si. The sources of the LCI data included 11 commercial European and U.S. photovoltaic module-manufacturing companies supplemented by numbers from the literature (Frischknecht et al., 2015). Detailed inputs and outputs describing the manufacturing of wafers, cells, and modules were estimated from actual production and operation facilities.

For each unit process in the production of the CS6X-P module, IEA PVPS data were classified and compiled into a LCI table. Before data calculation, mass and energy balances are checked between subsequent processes for data validation (PE International, 2010). Tables 9 through 13 describe how material and energy flows between processes in a "cradle-to-gate" boundary for mc-Si module manufacturing.

\section{Metallurgical Silicon}

The first level of the photovoltaic supply chain is the smelting of quarts of silica sand $\left(\mathrm{SiO}_{2}\right)$ into metallurgical silicon (mg-Si). Materials are heated to high temperatures to remove impurities in the form of slag as a by-product. Emissions are also released into the air from the smelting process. Table 9 shows the unit process data of the smelting process of $1 \mathrm{~kg}$ of mg-silicon. 
Table 9 - LCI data for mg-smelting (Frischknecht et al., 2015).

\begin{tabular}{|c|c|c|c|}
\hline & Flow & Value & Unit \\
\hline Product & MG-silicon, at plant & 1 & $\mathrm{~kg}$ \\
\hline \multirow{8}{*}{ Operating material } & $\begin{array}{l}\text { Electricity, medium voltage, at } \\
\text { grid }\end{array}$ & $1.10 \mathrm{E}+1$ & $\mathrm{kWh}$ \\
\hline & $\begin{array}{l}\text { Wood chips, mixed, } u=120 \% \text {, } \\
\text { at forest }\end{array}$ & $3.25 \mathrm{E}-3$ & $\mathrm{~m}^{3}$ \\
\hline & Hard coal coke, at plant & $2.31 \mathrm{E}+1$ & MJ \\
\hline & Graphite, at plant & $1.00 \mathrm{E}-1$ & $\mathrm{~kg}$ \\
\hline & Charcoal, at plant & $1.70 \mathrm{E}-1$ & $\mathrm{~kg}$ \\
\hline & Petroleum coke, at refinery & $5.00 \mathrm{E}-1$ & $\mathrm{~kg}$ \\
\hline & Silica sand, at plant & $2.70 \mathrm{E}+0$ & $\mathrm{~kg}$ \\
\hline & Oxygen, liquid, at plant & $2.00 \mathrm{E}-2$ & $\mathrm{~kg}$ \\
\hline Infrastructure & Silicone plant & $1.00 \mathrm{E}-11$ & unit \\
\hline \multirow[t]{2}{*}{ Waste } & $\begin{array}{l}\text { Disposal, slag from MG silicon } \\
\text { production, } 0 \% \text { water, to inert } \\
\text { material landfill }\end{array}$ & $2.50 \mathrm{E}-2$ & $\mathrm{~kg}$ \\
\hline & Heat, waste & $7.13 \mathrm{E}+1$ & MJ \\
\hline \multirow{27}{*}{$\begin{array}{l}\text { Emission air, low } \\
\text { population density }\end{array}$} & Arsenic & $9.42 \mathrm{E}-9$ & $\mathrm{~kg}$ \\
\hline & Aluminum & $1.55 \mathrm{E}-6$ & $\mathrm{~kg}$ \\
\hline & Antimony & $7.85 \mathrm{E}-9$ & $\mathrm{~kg}$ \\
\hline & Boron & $2.79 \mathrm{E}-7$ & $\mathrm{~kg}$ \\
\hline & Cadmium & $3.14 \mathrm{E}-10$ & $\mathrm{~kg}$ \\
\hline & Calcium & $7.75 \mathrm{E}-7$ & $\mathrm{~kg}$ \\
\hline & Carbon monoxide, biogenic & $6.20 \mathrm{E}-4$ & $\mathrm{~kg}$ \\
\hline & Carbon monoxide, fossil & $1.38 \mathrm{E}-3$ & $\mathrm{~kg}$ \\
\hline & Carbon dioxide, biogenic & $1.61 \mathrm{E}+0$ & $\mathrm{~kg}$ \\
\hline & Carbon dioxide, fossil & $3.58 \mathrm{E}+0$ & $\mathrm{~kg}$ \\
\hline & Chromium & $7.85 \mathrm{E}-9$ & $\mathrm{~kg}$ \\
\hline & Chlorine & $7.85 \mathrm{E}-8$ & $\mathrm{~kg}$ \\
\hline & Cyanide & $6.87 \mathrm{E}-6$ & $\mathrm{~kg}$ \\
\hline & Fluorine & $3.88 \mathrm{E}-8$ & $\mathrm{~kg}$ \\
\hline & Hydrogen sulfide & $5.00 \mathrm{E}-4$ & $\mathrm{~kg}$ \\
\hline & Hydrogen fluoride & $5.00 \mathrm{E}-4$ & $\mathrm{~kg}$ \\
\hline & Iron & $3.88 \mathrm{E}-6$ & $\mathrm{~kg}$ \\
\hline & Lead & $3.44 \mathrm{E}-7$ & $\mathrm{~kg}$ \\
\hline & Mercury & $7.85 \mathrm{E}-9$ & $\mathrm{~kg}$ \\
\hline & $\begin{array}{l}\text { NMVOC, non-methane volatile } \\
\text { organic compounds, } \\
\text { unspecified origin }\end{array}$ & $9.60 \mathrm{E}-5$ & $\mathrm{~kg}$ \\
\hline & Nitrogen oxides & $9.74 \mathrm{E}-3$ & $\mathrm{~kg}$ \\
\hline & Particulates, > 10 um & $7.75 \mathrm{E}-3$ & $\mathrm{~kg}$ \\
\hline & Potassium & $6.20 \mathrm{E}-5$ & $\mathrm{~kg}$ \\
\hline & Silicon & $7.51 \mathrm{E}-3$ & $\mathrm{~kg}$ \\
\hline & Sodium & $7.75 \mathrm{E}-7$ & $\mathrm{~kg}$ \\
\hline & Sulfur dioxide & $1.22 \mathrm{E}-2$ & $\mathrm{~kg}$ \\
\hline & Tin & $7.85 \mathrm{E}-9$ & $\mathrm{~kg}$ \\
\hline
\end{tabular}




\section{Solar Grade Silicon}

Solar grade silicon (sog-Si) is most commonly produced using the modified Siemens process, which further refines mg-Si to a purity of $>99.9 \%$. The $\mathrm{mg}$-Si is reacted with chemicals to produce silicon gas, either trichlorosilane or silane. The silicon gas is introduced into a thermal decomposition furnace to grow silicon rods that will be used as the polysilicon feedstock for PV systems (Khattak, et al., 2001). The modified Siemens process is a relatively closed system and most of the materials are recycled internally (Chen et al., 2016). The input and outputs for the purification of $1 \mathrm{~kg}$ of sog-Si are shown in Table 10.

Table 10 - LCI data for sog-Si purification (Frischknecht et al., 2015).

\begin{tabular}{|c|c|c|c|}
\hline & Flow & Value & Unit \\
\hline Product & $\begin{array}{l}\text { Silicon, solar grade, modified } \\
\text { Siemens process, at plant }\end{array}$ & 1 & $\mathrm{~kg}$ \\
\hline \multirow{6}{*}{ Operating material } & MG-silicon, at plant & $1.13 \mathrm{E}+0$ & $\mathrm{~kg}$ \\
\hline & $\begin{array}{l}\text { Hydrochloric acid, } 30 \% \text { in } \mathrm{H} 2 \mathrm{O} \text {, } \\
\text { at plant }\end{array}$ & $1.60 \mathrm{E}+0$ & $\mathrm{~kg}$ \\
\hline & Hydrogen, liquid, at plant & $5.01 \mathrm{E}-2$ & $\mathrm{~kg}$ \\
\hline & $\begin{array}{l}\text { Sodium hydroxide, } 50 \% \text { in } \\
\mathrm{H} 2 \mathrm{O} \text {, production mix, at plant }\end{array}$ & $3.48 \mathrm{E}-1$ & $\mathrm{~kg}$ \\
\hline & $\begin{array}{l}\text { Electricity, hydropower, at run- } \\
\text { of-river power plant }\end{array}$ & $1.10 \mathrm{E}+2$ & $\mathrm{kWh}$ \\
\hline & $\begin{array}{l}\text { Heat, at cogen } 1 \mathrm{MWe} \text { lean } \\
\text { burn, allocation exergy }\end{array}$ & $1.85 \mathrm{E}+2$ & MJ \\
\hline Infrastructure & Silicone plant & $1.00 \mathrm{E}-11$ & unit \\
\hline \multirow[t]{5}{*}{ Waste } & Heat, waste & $3.51 \mathrm{E}+2$ & MJ \\
\hline & $\begin{array}{l}\text { AOX, Absorbable Organic } \\
\text { Halogen as } \mathrm{Cl}\end{array}$ & $1.26 \mathrm{E}-5$ & $\mathrm{~kg}$ \\
\hline & $\begin{array}{l}\text { BOD5, Biological Oxygen } \\
\text { Demand }\end{array}$ & $2.05 \mathrm{E}-4$ & $\mathrm{~kg}$ \\
\hline & $\begin{array}{l}\text { COD, Chemical Oxygen } \\
\text { Demand }\end{array}$ & $2.02 \mathrm{E}-3$ & $\mathrm{~kg}$ \\
\hline & Chloride & $3.60 \mathrm{E}-2$ & $\mathrm{~kg}$ \\
\hline \multirow[t]{8}{*}{ Emission water, river } & Copper, ion & $1.02 \mathrm{E}-7$ & $\mathrm{~kg}$ \\
\hline & Nitrogen & $2.08 \mathrm{E}-4$ & $\mathrm{~kg}$ \\
\hline & Phosphate & $2.80 \mathrm{E}-6$ & $\mathrm{~kg}$ \\
\hline & Sodium, ion & $3.38 \mathrm{E}-2$ & $\mathrm{~kg}$ \\
\hline & Zinc, ion & $1.96 \mathrm{E}-6$ & $\mathrm{~kg}$ \\
\hline & Iron, ion & $5.61 \mathrm{E}-6$ & $\mathrm{~kg}$ \\
\hline & $\begin{array}{l}\text { DOC, Dissolved Organic } \\
\text { Carbon }\end{array}$ & $9.10 \mathrm{E}-4$ & $\mathrm{~kg}$ \\
\hline & TOC, Total Organic Carbon & $9.10 \mathrm{E}-4$ & $\mathrm{~kg}$ \\
\hline
\end{tabular}




\section{Silicon Ingots and Wafers}

Directional solidification of sog-Si is used to produce ingots. The polysilicon feedstock is melted in a crucible and a decrease in the thermal field forms ingots. The ingots are then cut into thin wafers using a wire saw slicing method. The inputs and outputs for ingot and $1 \mathrm{~m}^{2}$ area of wafer production are shown in Table 11.

Table 11 - LCI data for mc-Si ingot and wafer production (Frischknecht et al., 2015).

\begin{tabular}{|c|c|c|c|}
\hline & Flow & Value & Unit \\
\hline \multirow[t]{2}{*}{ Product } & mc-Si wafer, at plant & 1 & $\mathrm{~m}^{2}$ \\
\hline & $\begin{array}{l}\text { Electricity, medium voltage, } \\
\text { at grid }\end{array}$ & $2.08 \mathrm{E}+1$ & $\mathrm{kWh}$ \\
\hline Operating material & $\begin{array}{l}\text { Natural gas, burned in } \\
\text { industrial furnace low-NOx } \\
>100 \mathrm{~kW}\end{array}$ & $4.00 \mathrm{E}+0$ & MJ \\
\hline \multirow[t]{2}{*}{ Water } & Tap water, at user & $1.64 \mathrm{E}+2$ & $\mathrm{~kg}$ \\
\hline & $\begin{array}{l}\text { Silicon, mc-Si, casted, at } \\
\text { plant }\end{array}$ & $1.02 \mathrm{E}+0$ & $\mathrm{~kg}$ \\
\hline \multirow[t]{4}{*}{ Material } & Silicon carbide, at plant & $6.20 \mathrm{E}-1$ & $\mathrm{~kg}$ \\
\hline & $\begin{array}{l}\text { Silicon carbide, recycling, at } \\
\text { plant }\end{array}$ & $1.41 \mathrm{E}+0$ & $\mathrm{~kg}$ \\
\hline & Flat glass, uncoated, at plant & $4.08 \mathrm{E}-2$ & $\mathrm{~kg}$ \\
\hline & $\begin{array}{l}\text { Sodium hydroxide, } 50 \% \text { in } \\
\mathrm{H} 2 \mathrm{O} \text {, production mix, at } \\
\text { plant }\end{array}$ & $1.50 \mathrm{E}-2$ & $\mathrm{~kg}$ \\
\hline \multirow[t]{10}{*}{ Auxiliary material } & $\begin{array}{l}\text { Hydrochloric acid, } 30 \% \text { in } \\
\mathrm{H} 2 \mathrm{O} \text {, at plant }\end{array}$ & $2.70 \mathrm{E}-3$ & $\mathrm{~kg}$ \\
\hline & $\begin{array}{l}\text { Acetic acid, } 98 \% \text { in } \mathrm{H} 2 \mathrm{O} \text {, at } \\
\text { plant }\end{array}$ & $3.90 \mathrm{E}-2$ & $\mathrm{~kg}$ \\
\hline & Triethylene glycol, at plant & $2.18 \mathrm{E}-1$ & $\mathrm{~kg}$ \\
\hline & $\begin{array}{l}\text { Triethylene glycol, recycling, } \\
\text { at plant }\end{array}$ & $1.95 \mathrm{E}+0$ & $\mathrm{~kg}$ \\
\hline & $\begin{array}{l}\text { Dipropylene glycol } \\
\text { monomethyl ether, at plant }\end{array}$ & $3.00 \mathrm{E}-1$ & $\mathrm{~kg}$ \\
\hline & $\begin{array}{l}\text { Alkyl benzene sulfonate, } \\
\text { linear, petrochemical, at } \\
\text { plant }\end{array}$ & $2.40 \mathrm{E}-1$ & $\mathrm{~kg}$ \\
\hline & $\begin{array}{l}\text { Acrylic binder, } 34 \% \text { in } \mathrm{H} 2 \mathrm{O} \text {, } \\
\text { at plant }\end{array}$ & $3.85 \mathrm{E}-3$ & $\mathrm{~kg}$ \\
\hline & Brass, at plant & $7.44 \mathrm{E}-3$ & $\mathrm{~kg}$ \\
\hline & Steel, low-alloyed, at plant & $7.97 \mathrm{E}-1$ & $\mathrm{~kg}$ \\
\hline & Wire drawing, steel & $8.05 \mathrm{E}-1$ & $\mathrm{~kg}$ \\
\hline \multirow[t]{2}{*}{ Waste } & $\begin{array}{l}\text { Disposal, waste, silicon } \\
\text { wafer production, } 0 \% \text { water, } \\
\text { to underground deposit }\end{array}$ & $1.70 \mathrm{E}-1$ & $\mathrm{~kg}$ \\
\hline & Heat, waste & $7.49 \mathrm{E}+1$ & MJ \\
\hline \multirow[t]{2}{*}{ Infrastructure } & Wafer factory & $4.00 \mathrm{E}-6$ & unit \\
\hline & $\begin{array}{l}\text { COD, Chemical Oxygen } \\
\text { Demand }\end{array}$ & $2.95 \mathrm{E}-2$ & $\mathrm{~kg}$ \\
\hline \multirow[t]{3}{*}{ Emission water, river } & $\begin{array}{l}\text { BOD5, Biological Oxygen } \\
\text { Demand }\end{array}$ & $2.95 \mathrm{E}-2$ & $\mathrm{~kg}$ \\
\hline & $\begin{array}{l}\text { DOC, Dissolved Organic } \\
\text { Carbon }\end{array}$ & $1.11 \mathrm{E}-2$ & $\mathrm{~kg}$ \\
\hline & TOC, Total Organic Carbon & $1.11 \mathrm{E}-2$ & $\mathrm{~kg}$ \\
\hline
\end{tabular}




\section{Multi-Crystalline Photovoltaic Cells}

During the cell stage, wafers undergo several chemical baths to remove surface damage, reduce reflectivity and cleaning. A p-n junction is formed by dopant diffusion and the application and sintering of metallization paste creates electric circuits. Table 12 shows the inputs and outputs to process $1 \mathrm{~m}^{2}$ area of mc-Si PV cells.

Table 12 - LCI data for mc-Si cell processing (Frischknecht et al., 2015).

\begin{tabular}{|c|c|c|c|}
\hline & Flow & Value & Unit \\
\hline \multirow[t]{3}{*}{ Product } & Photovoltaic cell, mc-Si, at plant & 1 & $\mathrm{~m}^{2}$ \\
\hline & Tap water, at user & $2.51 \mathrm{E}+2$ & $\mathrm{~kg}$ \\
\hline & $\begin{array}{l}\text { Electricity, medium voltage, at } \\
\text { grid }\end{array}$ & $1.44 \mathrm{E}+1$ & $\mathrm{kWh}$ \\
\hline \multirow[t]{2}{*}{ Operating material } & $\begin{array}{l}\text { Natural gas, burned in industrial } \\
\text { furnace low-NOx }>100 \mathrm{~kW}\end{array}$ & $2.47 \mathrm{E}-1$ & MJ \\
\hline & $\begin{array}{l}\text { Light fuel oil, burned in industrial } \\
\text { furnace } 1 \mathrm{MW} \text {, non-modulating }\end{array}$ & $2.70 \mathrm{E}-3$ & MJ \\
\hline Infrastructure & Photovoltaic cell factory & 4.00E-7 & unit \\
\hline Wafers & mc-Si wafer, at regional storage & $1.04 \mathrm{E}+0$ & $\mathrm{~m} 2$ \\
\hline \multirow{3}{*}{ Materials } & $\begin{array}{l}\text { Metallization paste, front side, at } \\
\text { plant }\end{array}$ & $9.12 \mathrm{E}-3$ & $\mathrm{~kg}$ \\
\hline & $\begin{array}{l}\text { Metallization paste, back side, at } \\
\text { plant }\end{array}$ & $5.34 \mathrm{E}-3$ & $\mathrm{~kg}$ \\
\hline & $\begin{array}{l}\text { Metallization paste, back side, } \\
\text { aluminium, at plant }\end{array}$ & $5.96 \mathrm{E}-2$ & $\mathrm{~kg}$ \\
\hline \multirow{14}{*}{ Chemicals } & $\begin{array}{l}\text { Ammonia, liquid, at regional } \\
\text { storehouse }\end{array}$ & $8.92 \mathrm{E}-3$ & $\mathrm{~kg}$ \\
\hline & $\begin{array}{l}\text { Phosphoric acid, fertilizer grade, } \\
70 \% \text { in } \mathrm{H} 2 \mathrm{O} \text {, at plant }\end{array}$ & 8.63E-3 & $\mathrm{kg}$ \\
\hline & Phosphoryl chloride, at plant & $2.74 \mathrm{E}-2$ & $\mathrm{~kg}$ \\
\hline & Isopropanol, at plant & $8.10 \mathrm{E}-4$ & $\mathrm{~kg}$ \\
\hline & $\begin{array}{l}\text { Solvents, organic, unspecified, } \\
\text { at plant }\end{array}$ & $1.13 \mathrm{E}-2$ & $\mathrm{~kg}$ \\
\hline & $\begin{array}{l}\text { Calcium chloride, } \mathrm{CaCl} 2 \text {, at } \\
\text { regional storage }\end{array}$ & $3.15 \mathrm{E}-2$ & $\mathrm{~kg}$ \\
\hline & $\begin{array}{l}\text { Hydrochloric acid, } 30 \% \text { in } \mathrm{H} 2 \mathrm{O} \text {, } \\
\text { at plant }\end{array}$ & $8.59 \mathrm{E}-3$ & $\mathrm{~kg}$ \\
\hline & Hydrogen fluoride, at plant & $4.03 \mathrm{E}-1$ & $\mathrm{~kg}$ \\
\hline & Nitric acid, $50 \%$ in $\mathrm{H} 2 \mathrm{O}$, at plant & $2.93 \mathrm{E}-1$ & $\mathrm{~kg}$ \\
\hline & $\begin{array}{l}\text { Sodium hydroxide, } 50 \% \text { in } \mathrm{H} 2 \mathrm{O} \text {, } \\
\text { production mix, at plant }\end{array}$ & 7.07E-2 & $\mathrm{kg}$ \\
\hline & Lime, hydrated, packed, at plant & $2.18 \mathrm{E}-1$ & $\mathrm{~kg}$ \\
\hline & $\begin{array}{l}\text { Hydrogen peroxide, } 50 \% \text { in } \\
\mathrm{H} 2 \mathrm{O} \text {, at plant }\end{array}$ & $4.52 \mathrm{E}-4$ & $\mathrm{~kg}$ \\
\hline & Sulphuric acid, liquid, at plant & $1.01 \mathrm{E}-1$ & $\mathrm{~kg}$ \\
\hline & Refrigerant R134a, at plant & $2.73 E-5$ & $\mathrm{~kg}$ \\
\hline
\end{tabular}


Table 12 (continued)

\begin{tabular}{|c|c|c|c|}
\hline & Flow & Value & Unit \\
\hline \multirow[t]{2}{*}{ Chemicals } & $\begin{array}{l}\text { Potassium hydroxide, at regional } \\
\text { storage }\end{array}$ & $3.00 \mathrm{E}-2$ & $\mathrm{~kg}$ \\
\hline & $\begin{array}{l}\text { Ammonium sulphate, as } \mathrm{N} \text {, at } \\
\text { regional storehouse }\end{array}$ & $2.10 \mathrm{E}-2$ & $\mathrm{~kg}$ \\
\hline \multirow{3}{*}{ Gases } & Oxygen, liquid, at plant & $8.22 \mathrm{E}-3$ & $\mathrm{~kg}$ \\
\hline & Nitrogen, liquid, at plant & $1.35 \mathrm{E}+0$ & $\mathrm{~kg}$ \\
\hline & Silicon tetra hydride, at plant & $2.61 \mathrm{E}-3$ & $\mathrm{~kg}$ \\
\hline \multirow{18}{*}{$\begin{array}{l}\text { Emission air, high } \\
\text { population density }\end{array}$} & Heat, waste & $5.18 \mathrm{E}+1$ & MJ \\
\hline & Aluminium & 7.73E-6 & $\mathrm{kg}$ \\
\hline & Hydrogen fluoride & $6.90 \mathrm{E}-4$ & $\mathrm{~kg}$ \\
\hline & Lead & 7.73E-6 & $\mathrm{kg}$ \\
\hline & Silicon & $3.17 \mathrm{E}-8$ & $\mathrm{~kg}$ \\
\hline & Silver & 7.73E-6 & $\mathrm{kg}$ \\
\hline & Tin & 7.73E-6 & $\mathrm{kg}$ \\
\hline & Ammonia & $5.22 \mathrm{E}-4$ & $\mathrm{~kg}$ \\
\hline & Carbon dioxide, fossil & $6.82 \mathrm{E}-1$ & $\mathrm{~kg}$ \\
\hline & Hydrogen & $4.44 \mathrm{E}-4$ & $\mathrm{~kg}$ \\
\hline & $\begin{array}{l}\text { Ethane, 1,1,1,2-tetrafluoro-, } \\
\text { HFC-134a }\end{array}$ & $2.73 \mathrm{E}-5$ & $\mathrm{~kg}$ \\
\hline & Silicon nitride & $1.47 \mathrm{E}-4$ & $\mathrm{~kg}$ \\
\hline & Silicon dioxide & $6.00 \mathrm{E}-6$ & $\mathrm{~kg}$ \\
\hline & $\begin{array}{l}\text { NMVOC, non-methane volatile } \\
\text { organic compounds, unspecified } \\
\text { origin }\end{array}$ & $3.53 \mathrm{E}-4$ & $\mathrm{~kg}$ \\
\hline & Water & $5.96 \mathrm{E}+0$ & $\mathrm{~kg}$ \\
\hline & Nitric acid & 1.19E-4 & $\mathrm{kg}$ \\
\hline & Nitrogen oxides & $1.24 \mathrm{E}-2$ & $\mathrm{~kg}$ \\
\hline & Nitrogen dioxides & $3.64 \mathrm{E}-3$ & $\mathrm{~kg}$ \\
\hline
\end{tabular}

\section{PV module}

In the final stage of manufacturing, cells are assembled into a PV module. Cells are connected physically and electronically, and encapsulated by glass, plastic and an aluminum frame. Table 13 shows the inputs and outputs for assembling $1 \mathrm{~m}^{2}$ of PV module. 
Table 13 - LCI data for mc-Si PV module assembly (Frischknecht et al., 2015).

\begin{tabular}{|c|c|c|c|}
\hline & Flow & Value & Unit \\
\hline Product & $\begin{array}{l}\text { Photovoltaic panel, mc-Si, at } \\
\text { plant }\end{array}$ & 1 & $\mathrm{~m}^{2}$ \\
\hline \multirow[t]{2}{*}{ Technosphere } & $\begin{array}{l}\text { Electricity, medium voltage, at } \\
\text { grid }\end{array}$ & $3.73 E+0$ & kWh \\
\hline & $\begin{array}{l}\text { Diesel, burned in building } \\
\text { machine }\end{array}$ & $8.75 \mathrm{E}-3$ & MJ \\
\hline \multirow[t]{4}{*}{ Infrastructure } & Photovoltaic panel factory & $4.00 \mathrm{E}-6$ & unit \\
\hline & Tap water, at user & $5.03 E+0$ & $\mathrm{~kg}$ \\
\hline & Tempering, flat glass & $8.81 \mathrm{E}+0$ & $\mathrm{~kg}$ \\
\hline & Wire drawing, copper & $1.03 \mathrm{E}-1$ & $\mathrm{~kg}$ \\
\hline Cells & Photovoltaic cell, mc-Si, at plant & 9.35E-1 & $m^{2}$ \\
\hline \multirow{13}{*}{ Materials } & Aluminium alloy, AIMg3, at plant & $2.13 E+0$ & $\mathrm{~kg}$ \\
\hline & Tin, at regional storage & 1.29E-2 & $\mathrm{kg}$ \\
\hline & Lead, at regional storage & $7.25 \mathrm{E}-4$ & $\mathrm{~kg}$ \\
\hline & Silver, at regional storage & - & $\mathrm{kg}$ \\
\hline & Diode, unspecified, at plant & $2.81 \mathrm{E}-3$ & $\mathrm{~kg}$ \\
\hline & $\begin{array}{l}\text { Polyethylene, HDPE, granulate, } \\
\text { at plant }\end{array}$ & 2.38E-2 & $\mathrm{kg}$ \\
\hline & $\begin{array}{l}\text { Solar glass, low-iron, at regional } \\
\text { storage }\end{array}$ & $8.81 \mathrm{E}+0$ & $\mathrm{~kg}$ \\
\hline & Copper, at regional storage & 1.03E-1 & $\mathrm{kg}$ \\
\hline & $\begin{array}{l}\text { Glass fiber reinforced plastic, } \\
\text { polyamide, injection moulding, } \\
\text { at plant }\end{array}$ & $2.95 \mathrm{E}-1$ & $\mathrm{~kg}$ \\
\hline & Ethyl vinyl acetate, foil, at plant & $8.75 \mathrm{E}-1$ & $\mathrm{~kg}$ \\
\hline & Polyvinyl fluoride film, at plant & $1.12 \mathrm{E}-1$ & $\mathrm{~kg}$ \\
\hline & $\begin{array}{l}\text { Polyethylene terephthalate, } \\
\text { granulate, amorphous, at plant }\end{array}$ & $3.46 \mathrm{E}-1$ & $\mathrm{~kg}$ \\
\hline & Silicone product, at plant & $1.22 \mathrm{E}-1$ & $\mathrm{~kg}$ \\
\hline \multirow{7}{*}{ Auxiliary materials } & $\begin{array}{l}\text { Corrugated board, mixed fiber, } \\
\text { single wall, at plant }\end{array}$ & $7.63 \mathrm{E}-1$ & $\mathrm{~kg}$ \\
\hline & 1-propanol, at plant & $1.59 \mathrm{E}-2$ & $\mathrm{~kg}$ \\
\hline & EUR-flat pallet & $5.00 \mathrm{E}-2$ & unit \\
\hline & Hydrogen fluoride, at plant & $6.24 \mathrm{E}-2$ & $\mathrm{~kg}$ \\
\hline & Isopropanol, at plant & 1.47E-4 & $\mathrm{kg}$ \\
\hline & $\begin{array}{l}\text { Potassium hydroxide, at regional } \\
\text { storage }\end{array}$ & $5.14 \mathrm{E}-2$ & $\mathrm{~kg}$ \\
\hline & Soap, at plant & $1.16 \mathrm{E}-2$ & $\mathrm{~kg}$ \\
\hline \multirow{5}{*}{ Disposal } & $\begin{array}{l}\text { Disposal, municipal solid waste, } \\
22.9 \% \text { water, to municipal } \\
\text { incineration }\end{array}$ & $3.00 \mathrm{E}-2$ & $\mathrm{~kg}$ \\
\hline & $\begin{array}{l}\text { Disposal, polyvinyl fluoride, } \\
0.2 \% \text { water, to municipal } \\
\text { incineration }\end{array}$ & $1.12 \mathrm{E}-1$ & $\mathrm{~kg}$ \\
\hline & Disposal, plastics, mixture, & & \\
\hline & $\begin{array}{l}15.3 \% \text { water, to municipal } \\
\text { incineration }\end{array}$ & $1.64 \mathrm{E}+0$ & $\mathrm{~kg}$ \\
\hline & $\begin{array}{l}\text { Treatment, sewage, from } \\
\text { residence, to wastewater } \\
\text { treatment, class } 2\end{array}$ & 5.03E-3 & $\mathrm{m}^{3}$ \\
\hline \multirow{4}{*}{ Emission air } & Heat, waste & $1.34 \mathrm{E}+1$ & MJ \\
\hline & NMVOC, non-methane volatile & & \\
\hline & $\begin{array}{l}\text { organic compounds, } \\
\text { unspecified origin }\end{array}$ & 8.06E-3 & $\mathrm{kg}$ \\
\hline & Carbon dioxide, fossil & $2.18 \mathrm{E}-2$ & $\mathrm{~kg}$ \\
\hline
\end{tabular}




\subsubsection{Life Cycle Impact Assessment (LCIA)}

The impact assessment phase of an LCA evaluates the significance of potential environmental impacts using the above-mentioned LCI results. This process involves associating inventory data with specific environmental impact categories and category indicators to develop an understanding of impacts (ISO 14040, 2006). However, the impact assessment phase only addresses environmental issues that have been specified by the goal and scope, and cannot be considered a complete assessment of all environmental issues to the product system being studied. For the CS6X-P PV module, only environmental issues that arise from manufacturing processes within the cradle-to-gate boundary are considered. The impacts from manufacturing processes done in the plant will be evaluated. Environmental issues that may occur during: mining, transportation, use, recycling or disposal of the product will not be considered as they are outside the scope of this research.

Elements for the LCIA are both mandatory and optional. Mandatory elements include the selection of relevant impact categories, classification and characterization. GaBi sustainability software assigns inputs and outputs to appropriate impact categories and quantifies potential impacts according to characterization factors (PE International, 2010). Optional elements of an LCA study include normalization, grouping and weighting of results. There are different methods that can be used to perform an LCIA. This research used the CML method, which was developed by the Institute of Environmental Sciences at Leiden University in the Netherlands. It is an impact assessment method that restricts quantitative modelling to the early stages in the cause-effect chain to help limit uncertainties (PE International, 2010). Results are grouped into various impact categories. This study will consider global warming potential (GWP, 100 years) and primary energy demands (PED).

\subsection{Impact Indicators and Interpretation}

\subsubsection{Primary Energy Demand}

Primary energy is defined as the energy embodied in natural resources that have not undergone anthropogenic conversion and needs to be converted and transported to become usable energy (Yue, You, \& Darling, 2014). The total demand, valued as primary energy, during the life cycle of a product is also called the cumulative energy demand (CED), which 
includes the direct uses as well as the indirect or grey consumption of energy due to the use of construction materials, raw materials, and consumables. The evaluation of overall energy consumed during the manufacturing of a PV system is important in determining the efficiency of PV systems, such that energy inputs are directly related to GHG emissions (Wong et al., 2016).

\section{Energy Payback Time (EPBT)}

Energy payback time is defined as the period needed to compensate for total primary energy demand required through the life cycle of an energy supply system. In the case of this study, the EPBT is the time required for the CS6X-P PV module system to generate the same amount of energy that was used to produce the system itself.

Using the CED, EPBT will be calculated using the following formula:

$$
E P B T=\frac{C E D}{E_{\text {agen }}}
$$

where $E_{\text {agen }}$ represents the annual electricity generation (Fthenakis, Raugei, Kim, Alsema, Held, \& de Wild-Scholten, 2011).

In the previous Section 4.2.1, local conditions for Ontario were used to calculate the $\mathrm{E}_{\text {agen }}$ for the CS6X-P module. Recall that for an annual irradiation of $1150 \mathrm{kWh}$ per $\mathrm{m}^{2}$, the annual electricity generation would be $368 \mathrm{kWh}$ per $\mathrm{m}^{2}$.

\section{Energy Return on Investment (EROI)}

The energy return on investment (EROI) is used as an indicator to provide a numerical quantification of the benefits that come from using a particular energy system. It is a ratio that describes the energy produced by a system over its lifespan to the amount of energy consumed for system production (Lloyd \& Forest, 2010). The EROI represents how many times the system is able to payback the energy that was required to produce the system. If the system lifetime is known, then the EROI can be calculated using the EPBT using the following formula:

$$
E R O I=\frac{\text { lifetime }}{E P B T}
$$




\subsubsection{Greenhouse Gas (GHG) Emissions}

Greenhouse gases are both the natural and anthropogenic gaseous elements found in the atmosphere. They absorb and emit radiation within the spectrum of thermal infrared radiation emitted by the Earth's surface, atmosphere and clouds (Verbruggen, Moomaw, \& Nyboer, 2011). This causes the greenhouse effect and contributes to climate change. The main greenhouse gases include carbon dioxide $\left(\mathrm{CO}_{2}\right)$, nitrous oxide $\left(\mathrm{N}_{2} \mathrm{O}\right)$, methane $\left(\mathrm{CH}_{4}\right)$, and ozone $\left(\mathrm{O}_{3}\right)$. GHG emissions involve the measurement of direct emissions from manufacturing processes, as well as indirect emissions from materials and infrastructures. PV technology has a relatively low carbon footprint, as it emits almost no GHG emissions during operation. This is considered a key advantage of PV technologies when compared to traditional fossil fuel or nuclear technologies.

In this life cycle study, the GHG emissions will be used to evaluate how the combined effect of greenhouse gases in the atmosphere and their relative effectiveness in absorbing outgoing infrared radiation impact global warming potential (GWP). The GWP was developed as an index to allow comparisons of global warming impacts of different gases. The most common comparison is to report all GHG emissions relative to carbon dioxide over a specified time horizon, commonly 100 years (Verbruggen, Moomaw, \& Byboer, 2011; Yue, You, \& Darling, 2014).

Potential for $\mathrm{CO}_{2}$ Mitigation (PCM)

The PCM is defined as the equivalent $\mathrm{CO}_{2}$ emissions that may be avoided using a particular energy system (Stoppato, 2008). It is calculated using the following formula:

$$
P C M=E_{\text {agen }} \times(\text { Operation life }-E P B T) \times \mathrm{CO}_{2} \text { content }
$$

The potential for solar PV technology to mitigate $\mathrm{CO}_{2}$ emissions depends on the local energy mix for electricity generation in the region and the technology. For Ontario, the annual electricity generation for the CS6X-P module was previously calculated as $368 \mathrm{kWh}$ and the $\mathrm{CO}_{2}$ content is $4.10 \mathrm{E}-2 \mathrm{~kg} \mathrm{CO} / \mathrm{kWh}$ for the electricity sector (IESO, 2015).

\subsection{Results}

In a "cradle-to-gate" system boundary, the PV supply chain describes the handling of raw materials into parts and their assembly into a PV module. The existing supply chain for the 
production of a mc-Si PV module involves unit processes for parts based out of China and assembly processes based out of Ontario. The material and energy input and output flows are tracked between China and Ontario. For the purpose of this study the electricity consumed by each of China's mc-Si PV module manufacturers has been generalized across all sources of electricity supply. The Chinese power generation capacity consists of coal-fired power $(72.31 \%)$, hydropower $(21.93 \%)$, wind power $(4.35 \%)$, nuclear power $(1.18 \%)$, photovoltaic $(0.21 \%)$ and others $(0.02 \%)$ (NEA, 2012). Meanwhile, the electricity consumed by Ontario's mc-Si PV module manufacturers is based on electricity supply data from the IESO. The Ontario electricity mix consists of nuclear power (60.1\%), hydropower (23.6\%), gas/oil power (10\%), wind power (5.9\%), biofuel power $(0.3 \%)$ and photovoltaic $(0.2 \%)$ (IESO, 2015). GaBi sustainability software used these electricity mixes to calculate the energy demand and GHG emissions to measure the environmental and economic differences between the existing supply chain and an alternative supply chain in all of Ontario.

\subsection{China-Ontario Supply Chain}

In the case of the CS6X-P module manufactured by Canadian Solar, the current PV supply chain is based both out of China and Ontario. The unit processes for handling raw material and transforming them into parts is mostly done in China, where Canadian Solar owns subsidiary companies. The unit processes for mg-Si smelting through to mc-Si cell processing are done in China. The parts are shipped to Canada and assembled into a mc-Si PV module at their Guelph facility.

\section{Primary Energy Demand}

Based on the data from the IEA and GaBi, the total primary energy demand from renewable and nonrenewable resources (gross calorific value) for a CS6X-P module of $320 \mathrm{Wp}$ manufactured in China and assembled in Ontario was calculated as $3123 \mathrm{MJ}$, as shown in Table 14. The flows are broken down for each process unit. Using the weak point analysis tool available on $\mathrm{GaBi}$, flows that accounted for more than $10 \%$ of the total sum were emphasized in red. These flows represent the weak points of the mc-Si PV module life cycle, which have the most impact to the total sum of results. Flows accounting for less than $0.1 \%$ of the total sum are shown in grey and considered negligible. 
The primary energy demands were found to be mainly from nonrenewable energy sources. More than $90 \%$ of the contributing energy used for the production unit processes was from hard coal, natural gas, uranium, and crude oil. This is reflective of the electricity production in China, which is mainly produced by coal-fired power plants (OECD/IEA, 2016). The stage of sog-Si purification for mc-Si production contributed towards the most of total primary energy demand at approximately 55\%. This is mainly due to the large amounts of electricity required in the process. The unit processes of mg-Si smelting, ingot casting, wafer production and cell processing accounted for between $10 \%$ and $15 \%$, while module assembly performed in Ontario only accounted for $2 \%$ of total primary energy demands.

\section{GHG Emissions}

The calculated GWP of a CS6X-P module in the current PV supply chain was $263 \mathrm{~kg} \mathrm{CO}_{2}$ equivalent per panel or $24.0 \mathrm{~g} \mathrm{CO}_{2}$-equivalent per $\mathrm{kWh}$, given that a panel generates a total of $6670 \mathrm{kWh}$. The GHG emissions consist of mainly carbon dioxide (92.2\%), methane (6.5\%), and nitrous oxide (1.2\%), as shown in Table 15. The negative flow value of carbon dioxide indicates that there was an input of $\mathrm{CO}_{2}$ from the input side. These levels represent the $\mathrm{CO}_{2}$ that is used during generation of electricity. However, these negative emissions are small and contribute to only $1.5 \%$ of the total GHG emissions.

The most critical unit process was the purification of mg-Si into sog-Si, which accounted for approximately $54 \%$ of the GWP. This is mainly due to the high electricity consumption required for the modified Siemens process. The processes for mg-Si smelting, mc-Si casting, wafer production, and cell processing also had significant contributions to the GWP, each accounting for more than $10 \%$, because of high electricity consumption. High emission levels of GHGs are a result of electricity generation in China being dominated by coal-fired power plants. The lowest contributor to GWP, $0.2 \%$, was the PV module assembly unit process. This

is mainly because during assembly, the consumption of raw materials is relatively low with very little if any by-products being produced or emitted. Moreover, the assembly in Ontario is done in modern automated facilities meant to produce high quality product. 
Table 14 - Flow balance for the production of the CS6X-320P PV module assuming a Chinese supply chain weighted to represent the gross calorific energy demand from nonrenewable and renewable resources [MJ].

\begin{tabular}{|c|c|c|c|c|c|c|c|}
\hline & $\begin{array}{c}\text { mg-Si } \\
\text { smelting } \\
(\mathrm{CH}) \\
\end{array}$ & $\begin{array}{c}\text { sog-Si } \\
\text { Purification } \\
\text { via Modified } \\
\text { Siemens } \\
(\mathrm{CH})\end{array}$ & $\begin{array}{c}\text { mc-Si } \\
\text { Casting } \\
(\mathrm{CH})\end{array}$ & $\begin{array}{c}\text { mc-Si Wafer } \\
\text { Production } \\
(\mathrm{CH})\end{array}$ & $\begin{array}{c}\text { mc-Si Cell } \\
\text { Processing } \\
(\mathrm{CH})\end{array}$ & $\begin{array}{c}\text { mc-Si PV } \\
\text { Panel } \\
\text { Assembly } \\
(\mathrm{ON})\end{array}$ & $\begin{array}{c}\text { mc-Si PV } \\
\text { System Life } \\
\text { Cycle (CH- } \\
\text { ON) }\end{array}$ \\
\hline \multicolumn{8}{|c|}{ Non renewable energy resources } \\
\hline Crude oil & $4.15 E+00$ & $2.93 E+01$ & $5.90 \mathrm{E}+00$ & $7.81 \mathrm{E}+00$ & $5.18 \mathrm{E}+00$ & 4.30E-01 & $5.28 E+01$ \\
\hline Hard coal & $2.00 E+02$ & $1.44 \mathrm{E}+03$ & $2.91 \mathrm{E}+02$ & $3.82 E+02$ & $2.54 \mathrm{E}+02$ & $3.60 E-01$ & 2.57E+03 \\
\hline Lignite & 2.02E-01 & $6.84 E-01$ & 1.38E-01 & 1.83E-01 & $1.21 \mathrm{E}-01$ & 4.94E-02 & $1.38 E+00$ \\
\hline Natural gas & $1.03 E+01$ & $6.58 \mathrm{E}+01$ & $1.32 \mathrm{E}+01$ & $2.71 \mathrm{E}+01$ & $1.22 \mathrm{E}+01$ & $8.23 E+00$ & 1.37E+02 \\
\hline Peat & 7.99E-04 & 6.68E-03 & 1.34E-03 & 1.78E-03 & $1.18 E-03$ & $2.96 E-04$ & $1.21 E-02$ \\
\hline Uranium & $3.57 E+00$ & $3.06 \mathrm{E}+01$ & $6.16 \mathrm{E}+00$ & $8.11 \mathrm{E}+00$ & $5.40 \mathrm{E}+00$ & $4.29 \mathrm{E}+01$ & $9.68 \mathrm{E}+01$ \\
\hline \multicolumn{8}{|l|}{ Renewable energy resources } \\
\hline Geothermics & 1.63E-03 & $1.11 E-02$ & 2.24E-03 & $3.01 E-03$ & $1.97 E-03$ & 4.13E-03 & $2.41 E-02$ \\
\hline Hydropower & $1.16 \mathrm{E}+01$ & $1.02 E+02$ & $2.06 \mathrm{E}+01$ & $2.71 \mathrm{E}+01$ & $1.80 \mathrm{E}+01$ & $7.25 \mathrm{E}+00$ & 1.87E+02 \\
\hline Solar energy & $2.35 E+00$ & $1.98 \mathrm{E}+01$ & $3.99 E+00$ & $5.25 \mathrm{E}+00$ & $3.49 \mathrm{E}+00$ & $5.57 E-01$ & $3.55 E+01$ \\
\hline Wave energy & $4.97 E-13$ & $3.86 E-12$ & 7.77E-13 & $1.02 E-12$ & $6.80 E-13$ & $4.60 E-13$ & $7.29 E-12$ \\
\hline Wind power & $2.46 E+00$ & $2.14 \mathrm{E}+01$ & $4.31 \mathrm{E}+00$ & $5.68 \mathrm{E}+00$ & $3.78 \mathrm{E}+00$ & $3.82 \mathrm{E}+00$ & 4.15E+01 \\
\hline \multicolumn{8}{|l|}{ Material resources } \\
\hline Non renewable elements & $1.40 \mathrm{E}-10$ & 1.09E-09 & $2.19 E-10$ & 2.88E-10 & $1.92 E-10$ & $1.33 E-10$ & 2.06E-09 \\
\hline Renewable resources & $4.59 E-11$ & $3.56 E-10$ & 7.16E-11 & $9.42 E-11$ & $6.27 E-11$ & $4.25 E-11$ & $6.72 \mathrm{E}-10$ \\
\hline Total & $2.35 E+02$ & $1.71 E+03$ & $3.45 E+02$ & 4.64E+02 & 3.03E+02 & $6.36 \mathrm{E}+01$ & $3.12 E+03$ \\
\hline
\end{tabular}


Table 15 - Flow balance for the production of the CS6X-320P PV module assuming a Chinese supply chain using the CML global warming potential (GWP 100 years) weighting system [kg CO 2 -eq per panel].

\begin{tabular}{|c|c|c|c|c|c|c|c|}
\hline & $\begin{array}{c}\text { mg-Si } \\
\text { smelting } \\
(\mathrm{CH}) \\
\end{array}$ & $\begin{array}{c}\text { sog-Si } \\
\text { purification } \\
(\mathrm{CH})\end{array}$ & $\begin{array}{c}\text { mc-Si } \\
\text { casting } \\
(\mathrm{CH})\end{array}$ & $\begin{array}{c}\text { mc-Si wafer } \\
\text { production } \\
(\mathrm{CH})\end{array}$ & $\begin{array}{c}\text { mc-Si cell } \\
\text { processing } \\
(\mathrm{CH})\end{array}$ & $\begin{array}{c}\text { mc-Si PV } \\
\text { panel } \\
\text { assembly } \\
(\mathrm{ON})\end{array}$ & $\begin{array}{c}\text { mc-Si PV } \\
\text { system life } \\
\text { cycle (CH- } \\
\text { ON) }\end{array}$ \\
\hline \multicolumn{8}{|l|}{ Renewable resources } \\
\hline Carbon dioxide & $-2.52 E-01$ & $-2.16 E+00$ & $-4.34 \mathrm{E}-01$ & $-5.72 \mathrm{E}-01$ & $-3.80 \mathrm{E}-01$ & -3.63E-02 & $-3.83 E+00$ \\
\hline \multicolumn{8}{|l|}{ Inorganic emissions to air } \\
\hline Carbon dioxide & $2.06 \mathrm{E}+01$ & $1.31 \mathrm{E}+02$ & $2.63 \mathrm{E}+01$ & $3.51 E+01$ & $2.42 \mathrm{E}+01$ & 5.29E-01 & 2.37E+02 \\
\hline Carbon dioxide (biotic) & $5.65 \mathrm{E}+00$ & $2.25 \mathrm{E}+00$ & 4.53E-01 & 5.96E-01 & 3.97E-01 & 3.26E-02 & $9.38 \mathrm{E}+00$ \\
\hline Nitrogentriflouride & 7.36E-07 & $6.38 \mathrm{E}-06$ & $1.28 \mathrm{E}-06$ & $1.69 \mathrm{E}-06$ & $1.12 \mathrm{E}-06$ & $6.21 \mathrm{E}-07$ & 1.18E-05 \\
\hline Nitrous oxide & $2.55 E-01$ & $1.84 \mathrm{E}+00$ & $3.71 E-01$ & 4.94E-01 & $3.25 E-01$ & 1.98E-03 & $3.29 E+00$ \\
\hline Sulphur hexafluoride & 4.87E-10 & 3.34E-09 & $6.72 \mathrm{E}-10$ & $9.01 \mathrm{E}-10$ & $5.90 \mathrm{E}-10$ & 1.23E-09 & 7.22E-09 \\
\hline \multicolumn{8}{|l|}{ Organic emissions to air } \\
\hline NMVOC & $5.14 \mathrm{E}-05$ & $4.41 \mathrm{E}-04$ & 8.88E-05 & 1.17E-04 & 7.78E-05 & $1.71 \mathrm{E}-04$ & 9.47E-04 \\
\hline Methane & 1.34E+00 & $9.62 \mathrm{E}+00$ & $1.94 \mathrm{E}+00$ & $2.57 E+00$ & $1.70 \mathrm{E}+00$ & 3.38E-02 & 1.72E+01 \\
\hline Methane (biotic) & $2.01 \mathrm{E}-11$ & $0.00 \mathrm{E}+00$ & $0.00 E+00$ & $0.00 \mathrm{E}+00$ & $0.00 \mathrm{E}+00$ & $0.00 E+00$ & 2.01E-11 \\
\hline Total & $2.76 \mathrm{E}+01$ & $1.42 E+02$ & 2.86E+01 & $3.82 E+01$ & $2.62 E+01$ & 5.61E-01 & 2.63E+02 \\
\hline
\end{tabular}




\subsection{Ontario Supply Chain Alternative}

In the current PV supply chain, module assembly for the CS6X-P is performed in Ontario. For this study, an alternative supply chain was assumed where Ontario manufacturers are responsible for all unit processes in the "cradle-to-gate" system. The Ontario energy supply was applied to the LCI data from the IEA PVPS using GaBi sustainability software. Material and energy input and output flows were tracked specifically for Ontario.

\section{Primary Energy Demand}

The hypothetical Ontario-based PV supply chain has a total primary energy demand equivalent to $2142 \mathrm{MJ}$, as shown in Table 16. GaBi weak point analysis shows the flows broken down for each process unit. Critical flows accounting for more than $10 \%$ of the total sum are emphasized in red, negligible flows of less than $0.1 \%$ are shown in grey.

While total generation output by fuel type in the Province in 2015 was dominated by nuclear (60\%), then hydro (24\%) and natural gas (10\%) (Figure 14) (IESO, 2015), the leading primary energy demands for a PV supply chain in Ontario come from nuclear (66\%), natural gas $(15 \%)$, and hydro (11\%). This is due to the use of natural gas as a source of thermal energy in the smelting of mg-Si into sog-Si. Additionally, coal-fired power plants have been phased out of Ontario but coal still contributes $0.6 \%$ to the primary energy demands of the $\mathrm{PV}$ supply chain since it is used as a carbon material during the mg-Si smelting and sog-Si purification where silicon is heated to temperature of $1500^{\circ} \mathrm{C}$ and higher.

The GaBi results showed the energy demands being used at each individual process step. The sog-Si purification process was calculated as the most critical phase, accounting for $54 \%$ of the total primary energy demands. This is due to high electricity consumption required for the modified Siemens process. The unit process for mc-Si module assembly is responsible for as little as $2.6 \%$ of total primary energy demands, while all other unit processes are in the range of $8 \%$ to $15 \%$. 


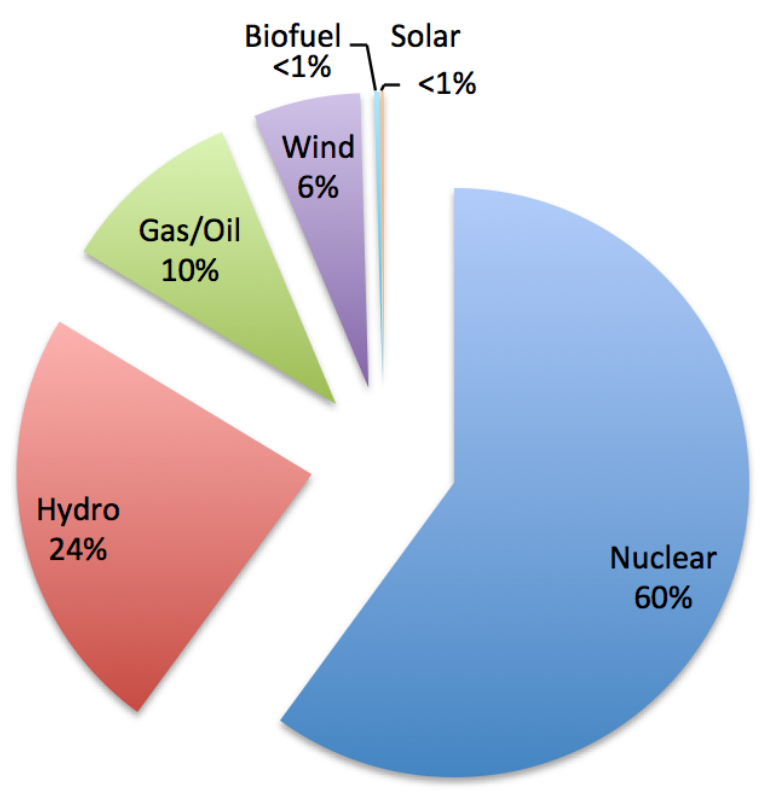

Figure 14 - Ontario energy output by fuel type (IESO, 2015).

\section{GHG Emissions}

Assuming an Ontario supply chain for the manufacturing of a CS6X-P module, the GWP was calculated as $32 \mathrm{~kg} \mathrm{CO}_{2}$-equivalent per panel or $2.85 \mathrm{~g} \mathrm{CO}_{2}$-equivalent per $\mathrm{kWh}$, given that a panel produces a total of $6670 \mathrm{kWh}$. From Table 17, we can see that carbon dioxide (95\%) was the main net contributor to total GHG emissions. From renewable resources, a negative carbon dioxide emission indicates the input of $\mathrm{CO}_{2}$ from renewable electricity generation. Inorganic emissions of $\mathrm{CO}_{2}$ were categorized as either biotic, emissions from natural processes via living matter, or abiotic, emissions from non-living matter. The majority of $\mathrm{CO}_{2}$ levels (78.4\%) were from inorganic abiotic $\mathrm{CO}_{2}$ emissions. Methane (4.7\%) was the only other significant contributor to GWP. Other emissions, which included nitrogen triflouride, nitrous oxide, sulphur hexafluoride and NMVOC, were negligible as they accounted for a combined total of $0.3 \%$ of the total GWP.

The mg-Si smelting and sog-Si purification processes in the hypothetical Ontario PV supply chain account for two thirds of the overall GWP, $37.3 \%$ and $33.7 \%$ respectively. The remaining GWP is split up among the remaining processes: mc-Si casting (6.8\%), wafer production (10.7\%), cell processing (9.6\%), and module assembly (1.8\%). 
Table 16 - Flow balance for the production of the CS6X-320P PV module assuming an Ontario supply chain weighted to represent the gross calorific primary energy demand from nonrenewable and renewable resources [MJ].

\begin{tabular}{|c|c|c|c|c|c|c|c|}
\hline & $\begin{array}{c}\text { mg-Si } \\
\text { smelting } \\
(\mathrm{ON})\end{array}$ & $\begin{array}{c}\text { sog-Si } \\
\text { purification } \\
\text { (ON) }\end{array}$ & $\begin{array}{c}\text { mc-Si } \\
\text { casting } \\
(\mathrm{ON})\end{array}$ & $\begin{array}{c}\text { mc-Si wafer } \\
\text { production } \\
(\mathrm{ON})\end{array}$ & $\begin{array}{c}\text { mc-Si cell } \\
\text { processing } \\
\text { (ON) }\end{array}$ & $\begin{array}{c}\text { mc-Si PV } \\
\text { panel } \\
\text { assembly } \\
(\mathrm{ON})\end{array}$ & $\begin{array}{c}\text { mc-Si PV } \\
\text { life cycle } \\
(\mathrm{ON})\end{array}$ \\
\hline \multicolumn{8}{|c|}{ Non renewable energy resources } \\
\hline Crude oil & $1.82 E+00$ & $8.81 \mathrm{E}+00$ & 1.77E+00 & $2.46 E+00$ & $1.57 \mathrm{E}+00$ & 4.30E-01 & 1.69E+01 \\
\hline Hard coal & $1.09 E+00$ & $7.37 \mathrm{E}+00$ & $1.48 E+00$ & $1.99 \mathrm{E}+00$ & $1.30 \mathrm{E}+00$ & 3.60E-01 & $1.36 \mathrm{E}+01$ \\
\hline Lignite & 2.40E-01 & $1.01 \mathrm{E}+00$ & 2.04E-01 & 2.72E-01 & 1.79E-01 & 4.94E-02 & $1.96 \mathrm{E}+00$ \\
\hline Natural gas & $6.86 \mathrm{E}+01$ & $1.69 \mathrm{E}+02$ & $3.39 \mathrm{E}+01$ & $5.48 \mathrm{E}+01$ & $3.03 E+01$ & $8.23 \mathrm{E}+00$ & $3.64 \mathrm{E}+02$ \\
\hline Peat & 8.96E-04 & 6.07E-03 & 1.22E-03 & 1.65E-03 & 1.07E-03 & 2.96E-04 & $1.12 E-02$ \\
\hline Uranium & $9.94 \mathrm{E}+01$ & $8.79 \mathrm{E}+02$ & $1.77 \mathrm{E}+02$ & $2.33 \mathrm{E}+02$ & $1.55 \mathrm{E}+02$ & $4.29 \mathrm{E}+01$ & $1.59 E+03$ \\
\hline \multicolumn{8}{|l|}{ Renewable energy resources } \\
\hline Geothermics & 9.83E-03 & 8.45E-02 & $1.70 E-02$ & 2.24E-02 & 1.49E-02 & 4.13E-03 & 1.53E-01 \\
\hline Hydropower & $1.68 \mathrm{E}+01$ & $1.49 \mathrm{E}+02$ & $2.99 \mathrm{E}+01$ & $3.93 \mathrm{E}+01$ & $2.62 \mathrm{E}+01$ & $7.25 \mathrm{E}+00$ & $2.68 \mathrm{E}+02$ \\
\hline Solar energy & $1.38 E+00$ & $1.14 \mathrm{E}+01$ & $2.30 \mathrm{E}+00$ & $3.02 \mathrm{E}+00$ & $2.01 E+00$ & 5.57E-01 & 2.07E+01 \\
\hline Wave energy & 1.12E-12 & $9.42 E-12$ & $1.90 \mathrm{E}-12$ & $2.50 \mathrm{E}-12$ & $1.66 \mathrm{E}-12$ & 4.60E-13 & $1.71 \mathrm{E}-11$ \\
\hline Wind power & $8.86 \mathrm{E}+00$ & $7.81 \mathrm{E}+01$ & $1.57 \mathrm{E}+01$ & $2.07 \mathrm{E}+01$ & $1.38 \mathrm{E}+01$ & $3.82 \mathrm{E}+00$ & $1.41 E+02$ \\
\hline \multicolumn{8}{|l|}{ Material resources } \\
\hline Non renewable elements & $3.24 E-10$ & 2.72E-09 & 5.48E-10 & $7.21 E-10$ & $4.80 E-10$ & 1.33E-10 & 4.93E-09 \\
\hline Renewable resources & $1.04 \mathrm{E}-10$ & $8.69 \mathrm{E}-10$ & $1.75 E-10$ & $2.30 \mathrm{E}-10$ & $1.53 E-10$ & 4.25E-11 & $1.57 \mathrm{E}-09$ \\
\hline Total & $1.98 \mathrm{E}+02$ & $1.30 \mathrm{E}+03$ & $2.62 \mathrm{E}+02$ & $3.55 \mathrm{E}+02$ & $2.30 \mathrm{E}+02$ & $6.36 \mathrm{E}+01$ & $2.41 E+03$ \\
\hline
\end{tabular}


Table 17 - Flow balance for the production of the CS6X-320P PV module assuming an Ontario supply chain using the CML global warming potential (GWP 100 years) weighting system [kg CO²-eq per panel].

\begin{tabular}{|c|c|c|c|c|c|c|c|}
\hline & $\begin{array}{c}\text { mg-Si } \\
\text { smelting } \\
(\mathrm{ON})\end{array}$ & $\begin{array}{c}\text { sog-Si } \\
\text { purification } \\
\text { (ON) }\end{array}$ & $\begin{array}{c}\mathrm{mc}-\mathrm{Si} \\
\text { casting }(\mathrm{ON})\end{array}$ & $\begin{array}{c}\text { mc-Si wafer } \\
\text { production } \\
\text { (ON) }\end{array}$ & $\begin{array}{c}\text { mc-Si cell } \\
\text { processing } \\
\text { (ON) }\end{array}$ & $\begin{array}{c}\text { mc-Si PV } \\
\text { panel } \\
\text { assembly } \\
(\mathrm{ON}) \\
\end{array}$ & $\begin{array}{c}\text { mc-Si PV } \\
\text { life cycle } \\
\text { (ON) }\end{array}$ \\
\hline \multicolumn{8}{|l|}{ Renewable resources } \\
\hline Carbon dioxide & $-9.07 E-02$ & $-7.43 E-01$ & $-1.50 \mathrm{E}-01$ & $-1.97 \mathrm{E}-01$ & $-1.31 \mathrm{E}-01$ & $-3.63 E-02$ & $-1.35 E+00$ \\
\hline \multicolumn{8}{|l|}{ Inorganic emissions to air } \\
\hline Carbon dioxide & $6.11 \mathrm{E}+00$ & $9.97 \mathrm{E}+00$ & $2.01 \mathrm{E}+00$ & $3.16 \mathrm{E}+00$ & $2.92 \mathrm{E}+00$ & 5.29E-01 & 2.47E+01 \\
\hline Carbon dioxide (biotic) & $5.47 \mathrm{E}+00$ & $6.67 \mathrm{E}-01$ & $1.34 \mathrm{E}-01$ & 1.77E-01 & $1.18 \mathrm{E}-01$ & 3.26E-02 & $6.60 \mathrm{E}+00$ \\
\hline Nitrogentriflouride & $1.45 \mathrm{E}-06$ & 1.27E-05 & 2.56E-06 & 3.37E-06 & $2.24 \mathrm{E}-06$ & 6.21E-07 & 2.30E-05 \\
\hline Nitrous oxide & $9.74 \mathrm{E}-03$ & 4.05E-02 & 8.15E-03 & 1.16E-02 & $7.20 \mathrm{E}-03$ & 1.98E-03 & 7.92E-02 \\
\hline Sulphur hexafluoride & 2.93E-09 & $2.52 E-08$ & 5.06E-09 & 6.68E-09 & 4.44E-09 & 1.23E-09 & $4.55 \mathrm{E}-08$ \\
\hline \multicolumn{8}{|l|}{ Organic emissions to air } \\
\hline NMVOC & 3.96E-04 & $3.49 \mathrm{E}-03$ & 7.03E-04 & $9.25 \mathrm{E}-04$ & $6.16 \mathrm{E}-04$ & $1.71 \mathrm{E}-04$ & $6.30 \mathrm{E}-03$ \\
\hline Methane & $2.71 \mathrm{E}-01$ & 6.93E-01 & $1.39 \mathrm{E}-01$ & $2.23 E-01$ & $1.24 \mathrm{E}-01$ & 3.38E-02 & $1.48 \mathrm{E}+00$ \\
\hline Methane (biotic) & 2.01E-11 & $0.00 \mathrm{E}+00$ & $0.00 \mathrm{E}+00$ & $0.00 \mathrm{E}+00$ & $0.00 \mathrm{E}+00$ & $0.00 \mathrm{E}+00$ & $2.01 \mathrm{E}-11$ \\
\hline Total & $1.18 \mathrm{E}+01$ & $1.06 \mathrm{E}+01$ & $2.14 \mathrm{E}+00$ & 3.37E+00 & $3.03 E+00$ & $5.61 \mathrm{E}-01$ & $3.15 E+01$ \\
\hline
\end{tabular}




\subsection{Comparing Supply Chains}

The current PV supply chain, where parts manufactured in China and assembled in Ontario, was compared to a hypothetical Ontario-based supply chain. The main difference between supply chain models is the local electricity mixes that are used. China is dominated by coalfired power plants, whereas Ontario has a cleaner supply mix that is mostly based on nuclear and hydropower. The energy demand and GHG emissions for each supply chain were compared to determine economic and environmental differences in solar panel manufacturing.

\subsubsection{Primary Energy Demand}

The existing PV supply chain has a total primary energy demand of $3.12 \mathrm{E}+3 \mathrm{MJ}$ or $8.67 \mathrm{E}+2$ kWh for a CS6X-P module, whereas the alternative Ontario supply chain would have a primary energy demand of $2.41 \mathrm{E}+3 \mathrm{MJ}$ or $6.70 \mathrm{E}+2 \mathrm{kWh}$ (Tables 14 and 16). Higher primary energy demands for China are due to the dominating role of coal-fired power plants in China. Of all types of electricity generation, coal demands the most primary energy (Fu, Liu, \& Yuan, 2015). Ontario does not rely on coal-fired power plants for electricity generation, and as a result has a much lower primary energy demand when compared to China.

In Figure 15, the primary energy demands for the two supply chain scenarios are shown for each unit process and compared side-by-side. For the mg-Si smelting process, the use of an Ontario electricity supply would reduce energy demands by $15.5 \%$ compared to the use of a Chinese electricity supply. The other unit processes, from sog-Si purification through to mcSi processing, would see reductions by approximately $23.8 \%$. There is no change in energy demand for the assembly process since the existing supply chain already utilizes Ontario manufacturers for assembly.

Energy Payback Time (EBPT)

The EPBT is a representation of the amount of energy the system needs to produce to payback the amount of energy used for its production. In this study, the energy demand for the two supply scenarios were used to determine EPBT for operation in Ontario. The solar radiation levels for Ontario were averaged at $1150 \mathrm{kWh} / \mathrm{m}^{2}$ and annual electricity 
generation was calculated as $368 \mathrm{kWh}$ (See Table 18). Using Eq. 6 as mentioned in Section 4.3.1, the Eagen was used to calculate EPBT for both supply chain scenarios.

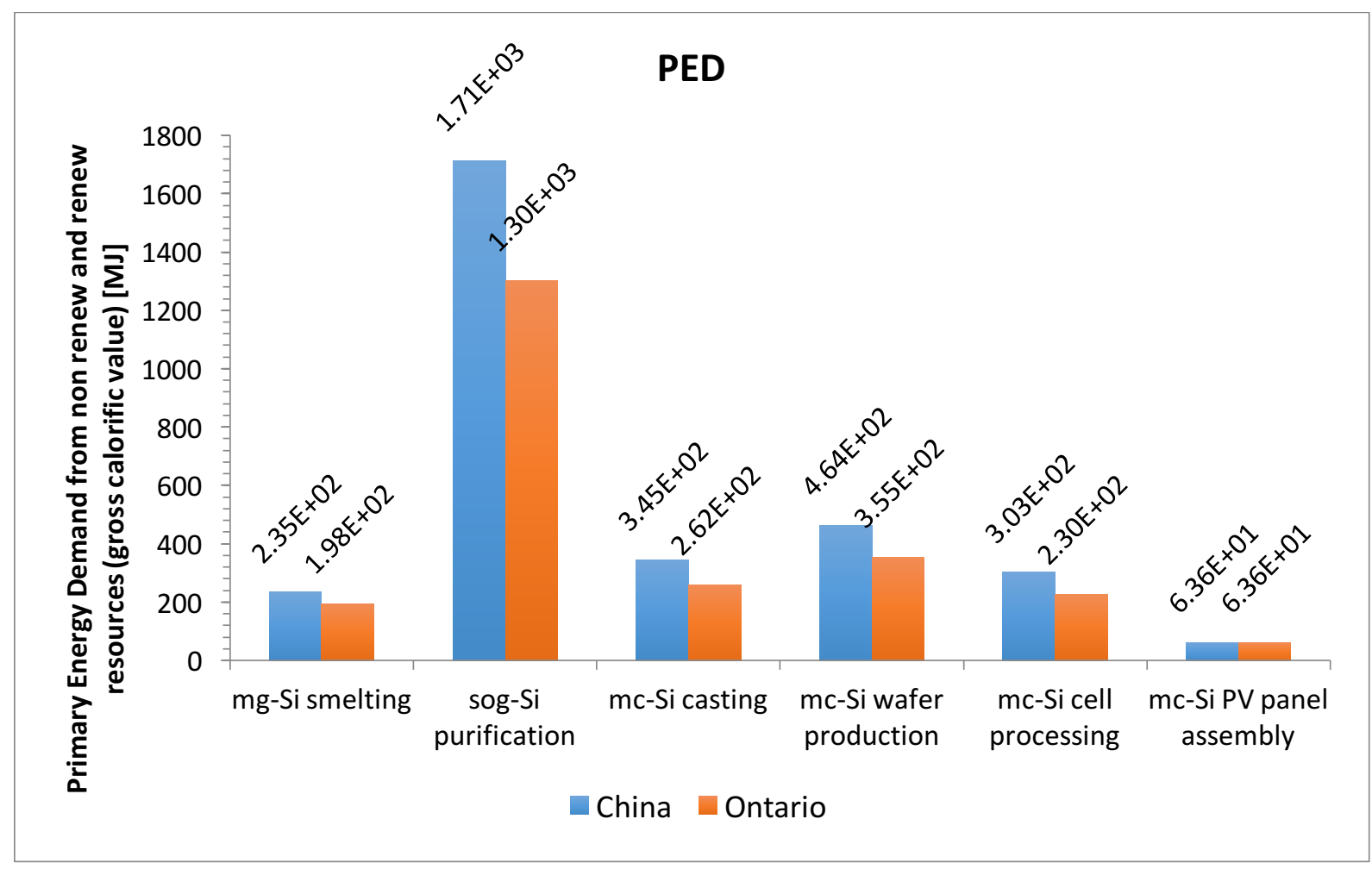

Figure 15 - Comparing primary energy demand totals between China and Ontario for each unit process of the CS6X-320P mc-Si PV module life cycle.

Table 18 - Electricity production and $\mathrm{CO}^{2}$ emissions for Ontario (IEA, 2015; IESO, 2015).

\begin{tabular}{lc}
\hline \multicolumn{1}{c}{ Variable } & Value \\
\hline Irradiation $(\mathbf{k W h} / \mathbf{m} 2)$ & 1150 \\
$\mathrm{CO}_{2}$ Content $\left(\mathbf{k g ~ C O} \mathbf{~ O}_{2} / \mathbf{k W h}\right)$ & $4.10 \mathrm{E}-2$ \\
\hline Annual Electricity Generation (kWh) & 368 \\
\hline
\end{tabular}

$$
\begin{gathered}
E P B T=\frac{C E D}{E_{\text {agen }}} \\
E P B T=\frac{8.67 \mathrm{E}-2 \mathrm{kWh}}{368 \mathrm{kWh}} \\
E P B T=2.36 \text { years }
\end{gathered}
$$

The existing PV supply chain, with production of parts in China and assembly in Ontario, was calculated to require 2.36 years of use in Ontario to payback the energy used during production. While the alternative supply chain scenario using all Ontario manufacturing 
would have a lower payback time of 1.82 years. These differences can be explained by the differences in energy supply, which impact the energy demands during manufacturing.

\section{Energy Return on Investment (EROI)}

The EROI is the ratio between the system life span and the EBPT. The CS6X-P module has a life span of 25 years. Using Equation 7 from Section 4.3.1, EROI was calculated for the two supply chain scenarios, China and Ontario, as shown in Table 19.

$$
\begin{gathered}
E R O I=\frac{\text { lifetime }}{E P B T} \\
E R O I=\frac{25 \text { years }}{2.35 \text { years }} \\
E R O I=10.61
\end{gathered}
$$

Based on the EPBT values, the EROI for existing PV supply chain practices is 10.6 . While an alternative Ontario-based supply chain would have an EROI of 13.4. These values represent the amount of times the CS6X-P system is able to payback the initial energy requirements. These results suggest that there is a greater return on investment given the alternative supply chain scenario.

\subsubsection{GHG Emissions}

The existing supply chain for China-Ontario has GHG emission levels equal to $2.63 \mathrm{E}+2 \mathrm{~kg} \mathrm{CO}_{2}$ equivalent per panel or $24.0 \mathrm{~g} \mathrm{CO}_{2}$ equivalent per $\mathrm{kWh}$, whereas the alternative Ontariobased supply chain has $3.15 \mathrm{E}+1 \mathrm{~kg} \mathrm{CO}$ equivalent per panel or $2.85 \mathrm{~g} \mathrm{CO}_{2}$ equivalent per $\mathrm{kWh}$. Emissions are higher for China-based production due to the continued use of coal-fired power plants. Ontario has lower emission levels because of a cleaner electricity mix; however, thermal energy production for mg-Si smelting and sog-Si purification produce significant amounts of emissions contributing to overall levels.

The emission levels for the two supply chain scenarios are shown in Figure 16, the individual unit processes are compared. The current supply chain emission levels are about 11.7 times more than that of Ontario-based supply chain with the exception of the mg-Si smelting and panel assembly processes. If mg-Si smelting occurred in Ontario, emission levels would be cut by almost half. There would be no change in panel assembly since it is a process that is already performed by Ontario manufacturers. When comparing the manufacturing 
processes used in the "cradle-to-gate" life cycle of the CS6X-P module, an Ontario supply chain produces about $88 \%$ fewer GHG emissions than the current Chinese supply chain.

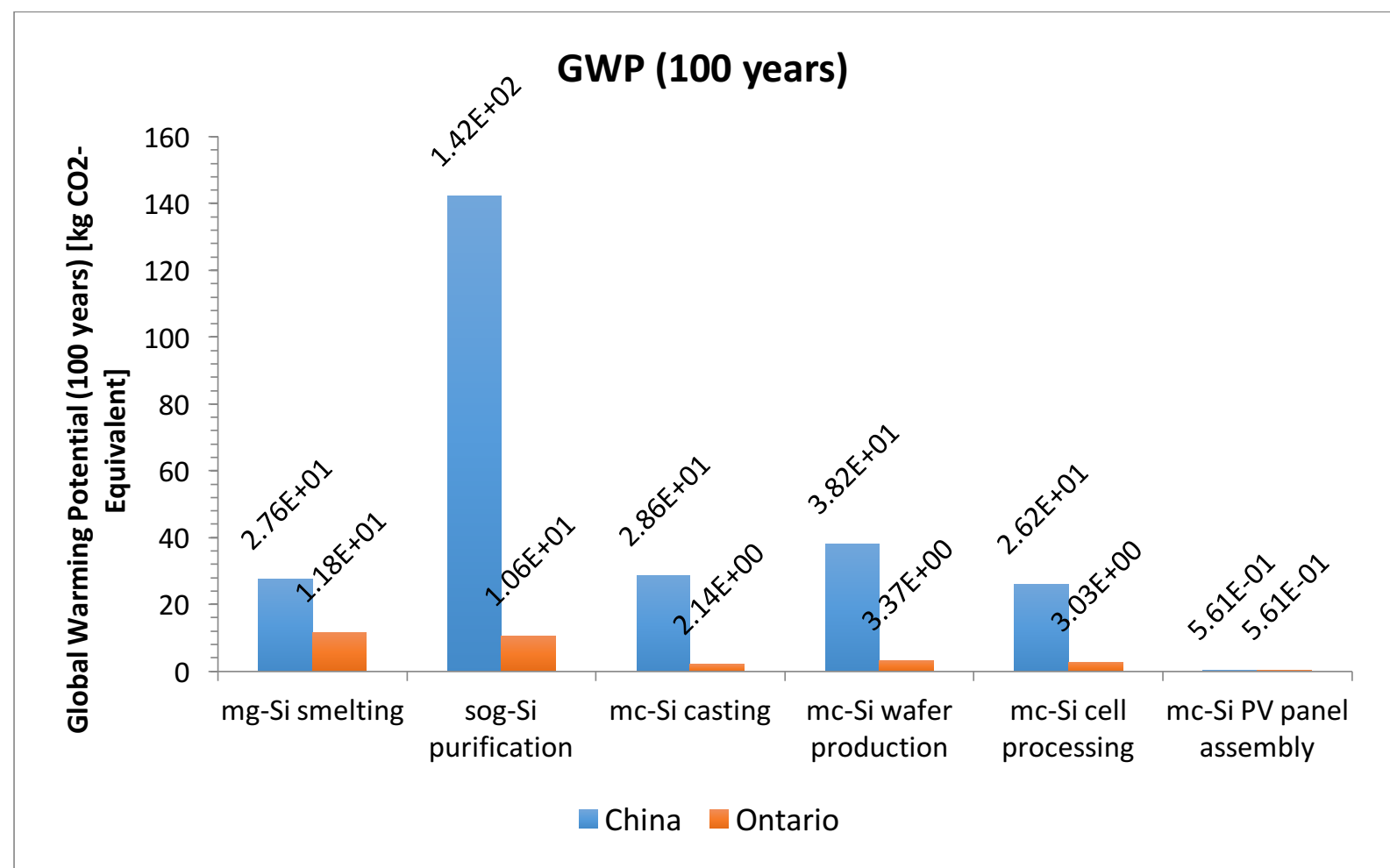

Figure 16 - The global warming potential compared between China and Ontario for each unit process of the CS6X-320P mc-Si PV module life cycle.

Potential for $\mathrm{CO}_{2}$ Mitigation (PCM)

The PCM in this study represents the amount of equivalent $\mathrm{CO}_{2}$ emissions that may be avoided by using the CS6X-P module system for electricity generation. Using Equation 8 from Section 4.3.2, PCM considers the annual electricity generation and the current $\mathrm{CO}_{2}$ content for the electricity sector within Ontario. The results showed that using a module from the China-Ontario supply chain would have a potential to mitigate about 3.42E-1 tonnes of $\mathrm{CO}_{2} / \mathrm{kWp}$ annually, while using panels manufactured using an Ontario-based supply chain would have the potential to avoid 3.50E-1 tonnes of $\mathrm{CO}_{2}$ annually (Table 19).

By year-end of 2014, annual $\mathrm{CO}_{2}$ emissions in the electricity sector for Ontario were reported at 78.2 megatonnes (Government of Canada, 2016). While the potential $\mathrm{CO}_{2}$ mitigated from using the CS6X-P module for both supply chain scenarios is only about $0.4 \%$, the Ontario supply chain is slightly more beneficial than the China-based supply chain. 


\section{Carbon Taxing}

Using the carbon emission differences between supply chain scenarios (Eq. 9), we apply a carbon value of $\$ 30$ per tonne (Eq. 10). This is based on carbon tax rates for British Columbia as of 2012 (Murray \& Rivers, 2015).

$$
\begin{aligned}
& 24.0 \mathrm{~g} \mathrm{CO}_{2} / \mathrm{kWh}-2.85 \mathrm{~g} \mathrm{CO}_{2} / \mathrm{kWh}=21.2 \mathrm{~g} \mathrm{CO}_{2} / \mathrm{kWh} \\
& 21.2 \mathrm{~g} \frac{\mathrm{CO}_{2}}{k W h} \times \$ 3.00 \mathrm{E}-5 / \mathrm{gCO}_{2}=\$ 6.35 \mathrm{E}-4 / \mathrm{kWh} \\
& \$ 6.35 \mathrm{E}-4 / \mathrm{kWh} \times 9200 \mathrm{kWh} / \mathrm{panel}=\$ 5.84 / \mathrm{panel}
\end{aligned}
$$

There is a difference of $21.15 \mathrm{~g} \mathrm{CO}_{2} / \mathrm{kWh}$ between the two supply chain scenarios (Eq. 9). The carbon value, priced at $\$ 30$ per tonne, for this difference was calculated at $\$ 6.35 \mathrm{E}-4$ per kWh or $\$ 5.84$ per panel (Eq 10 and Eq. 11).

Table 19 - Calculated results of impact assessment for CS6X-320P mc-Si PV module.

\begin{tabular}{lccccc} 
& $\begin{array}{c}\text { GWP } \\
\left(\mathbf{g ~} \mathbf{~ C O}_{\mathbf{2}} \mathbf{~ e q} / \mathbf{k W h}\right)\end{array}$ & CED (kWh) & EPBT (years) & EROI & $\begin{array}{c}\text { PCM (tonnes } \\
\mathbf{C O 2 / y e a r )}\end{array}$ \\
\hline China/Ontario & 24.0 & $8.67 \mathrm{E} 2$ & 2.36 & 10.6 & $3.42 \mathrm{E}-1$ \\
Ontario & 2.85 & $6.70 \mathrm{E} 2$ & 1.82 & 13.4 & $3.50 \mathrm{E}-1$
\end{tabular}

\subsection{Discussion}

\subsection{Assessment of an Ontario Market}

Solar energy is a clean technology for electricity generation but the manufacturing processes involved in the development of the technology produces a measurable carbon footprint. This research used a LCA approach to calculate environmental impacts of the PV supply chain for two different demand sites, China and Ontario. By comparing these two supply chain scenarios, a review of social, environmental, economic, and political factors was completed to provide insight into the potential expansion of Ontario's role in solar PV manufacturing.

In the current supply chain, material processing and parts manufacturing is based out of China with assembly done in Ontario. Module assembly and installation are the only service that Ontario companies offer. From a social perspective, the undertaking of more supply chain activities would help generate more green jobs in the solar sector. These jobs would require training a more specialized workforce with higher wages. Compared to China, these wages seem high; however, when taking into consideration that China's wage structures may 
be exploitive in nature, these wages represent fair pay. Unfortunately, lower labour and regulatory costs in China as compared to Ontario are more attractive to global business investors. As a result, this can affect the overall affordability of solar panels on the consumer end. However, when considering the environmental perspective, manufacturing in Ontario does have the added benefit of reduced environmental impacts. The energy mix in Ontario leads to lower PED and GWP values, which contributes to an overall smaller carbon footprint when compared to solar panels produced in China.

The LCA results of this study indicate that the development of new operations for sog-Si purification, mc-Si casting, and mc-Si cell processing in Ontario would have the largest impact; generating green jobs and reducing environmental impacts. These operations would produce raw materials and goods ready for export, adding economic value to the solar industry in Ontario. While it would be hard to compete against China, since Ontario labour costs are high, government programs and initiatives for green energy can help support the domestic market. The recent import tariffs on Chinese solar panels could support the potential for an Ontario-based PV supply chain but there are also concerns that it could cause a decrease in demand because of higher costs for the end user.

\subsection{Feasibility}

In the discussion for an Ontario-based PV supply chain, environmental benefits are a leading consideration. While it is important that we minimize our impact on the environment, we must still be able to meet our needs. The balance between the environment and the economy is necessary.

By using British Columbia's carbon tax of $\$ 30$ per tonne $\mathrm{CO}_{2}$ as a proxy for Ontario carbon pricing, we evaluate how environmental benefits can be translated to an economic value. The carbon emission difference for the CS6X-P PV module was calculated as $\$ 0.0006$ per kWh generation or $\$ 5.84$ per panel of taxable carbon. While GHG emissions would be reduced by almost $88 \%$, the cost savings in emissions and process energy is not significant enough to encourage a PV supply chain in Ontario given current carbon policies.

While the results of this study suggest that a made in Ontario supply chain is not currently feasible, there may be additional economic advantages to be gained from trade tariffs. The 
environmental benefits and energy usage advantages in Ontario alone are not enough to encourage a supply chain shift but when combined with the existing tariffs, there is a slight increase in cost advantage. However, an in-depth economic analysis on impact of the trade tariff structure was outside the scope of this study. Moreover, current carbon policies for Ontario could be improved upon to better address carbon pollution levels, such that incentives are created for companies to make cleaner choices during manufacturing.

\subsection{Conclusions}

This study compared solar PV module supply chain scenarios for China and Ontario to determine the differences in cost, in terms of environmental impact, as an indicator to determine the potential of an Ontario-based supply chain. The unit processes included in this analysis were described by a "cradle-to-gate" boundary: mg-Si smelting, sog-Si purification, mc-Si casting, mc-Si wafer production, mc-Si cell processing, and mc-Si PV panel assembly. In a review of current supply chain activities, it was found that the majority of processes are based out of China with the exception of module assembly, which is done in Ontario. In order to determine the potential for a made in Ontario PV supply chain, a LCA approach was used to perform a comparative analysis of the environmental and economic cost for solar manufacturing in Ontario.

The CS6X-P module manufactured by Canadian Solar was selected for the case study due to its popularity. It is a mc-Si PV module consisting of 72 cells and a surface area of $1.9 \mathrm{~m}^{2}$. From the LCA analysis, PED and GWP values were calculated for each of the supply chain scenarios. The PED in China was calculated as $867 \mathrm{kWh} /$ module and the GWP was $24.0 \mathrm{~g}$ of equivalent $\mathrm{CO}_{2} / \mathrm{kWh}$; values for Ontario were calculated as $670 \mathrm{kWh} /$ module and $2.85 \mathrm{~g}$ of equivalent $\mathrm{CO}_{2} / \mathrm{kWh}$ respectively. Additionally, EBPT and EROI values suggest quicker energy payback and better energy return on investment than China. Overall, the LCA results support the idea that PV module production would be better suited in Ontario when considering environmental impacts. In terms of economic value, the carbon difference between supply chains was calculated to be $\$ 0.0006$ per $\mathrm{kWh}$ generation or $\$ 5.84$ per panel. Thus, the combined economic value of the lower process energy usage and the environmental cost savings for an Ontario-based PV supply chain compared to China is not significant enough at this time to suggest a change in the current supply chain. However, if carbon policies were 
designed to better address carbon pollution using stricter pricing schemes, there would be clearer incentive in terms of both environmental and economic costing to support an Ontario-based supply chain.

\subsection{Study Limitations}

This study used secondary sourced inventory from the IEA Photovoltaic Power Systems Programme (PVPS) for the LCA calculations. The data are an average for 11 commercial European and U.S. photovoltaic module manufacturing companies with supplemented number from literature. It would have been ideal to use primary sourced data; however, a working relationship with industry could not be secured. Additionally, GaBi sustainability software did not offer a dataset available for the electricity mix in Ontario through their education license. Instead the electricity mix was modeled after eastern U.S. electricity generation and scaled according to IESO data.

\subsection{Future Research Recommendations}

Future work should attempt to acquire primary data from existing Solar PV manufacturers in Ontario in order to provide a more accurate LCA for the current and potential Ontario supply chains. Furthermore, an evaluation of how the import tariffs impact the use of solar PVs in Ontario and whether or not the environmental cost savings of an Ontario-based PV

supply chain combined with those tariffs could become significant enough to suggest a change in the current supply chain. 


\section{Appendices}

\section{Appendix A - Energy Statistics for China}

Table A-1 - Energy balances for China 2013 in thousand tonnes of oil equivalent (ktoe) on a net calorific value basis (OECD/IEA, 2016).

\begin{tabular}{|c|c|c|c|c|c|c|c|c|c|c|c|}
\hline & Coal $^{*}$ & Crude oil* & Oil products & Natural gas & Nuclear & Hydro & $\begin{array}{l}\text { Geothermal, } \\
\text { solar, etc. }\end{array}$ & $\begin{array}{r}\text { Biofuels and } \\
\text { waste }\end{array}$ & Electricity & Heat & Total $^{* *}$ \\
\hline Production & 1894677 & 210101 & 0 & 101115 & 29087 & 78227 & 36711 & 215757 & 0 & 0 & 2565674 \\
\hline Imports & 174105 & 281742 & 53757 & 41656 & 0 & 0 & 0 & 0 & 640 & 0 & 551900 \\
\hline Exports & -9268 & -1617 & -33212 & -2297 & 0 & 0 & 0 & 0 & -1606 & 0 & -47999 \\
\hline International marine bunkers ${ }^{\star \star \star}$ & 0 & 0 & -7714 & 0 & 0 & 0 & 0 & 0 & 0 & 0 & -7714 \\
\hline International aviation bunkers ${ }^{\star \star \star}$ & 0 & 0 & -7001 & 0 & 0 & 0 & 0 & 0 & 0 & 0 & -7001 \\
\hline Stock changes & -35147 & -3334 & -6907 & 0 & 0 & 0 & 0 & 0 & 0 & 0 & -45388 \\
\hline
\end{tabular}

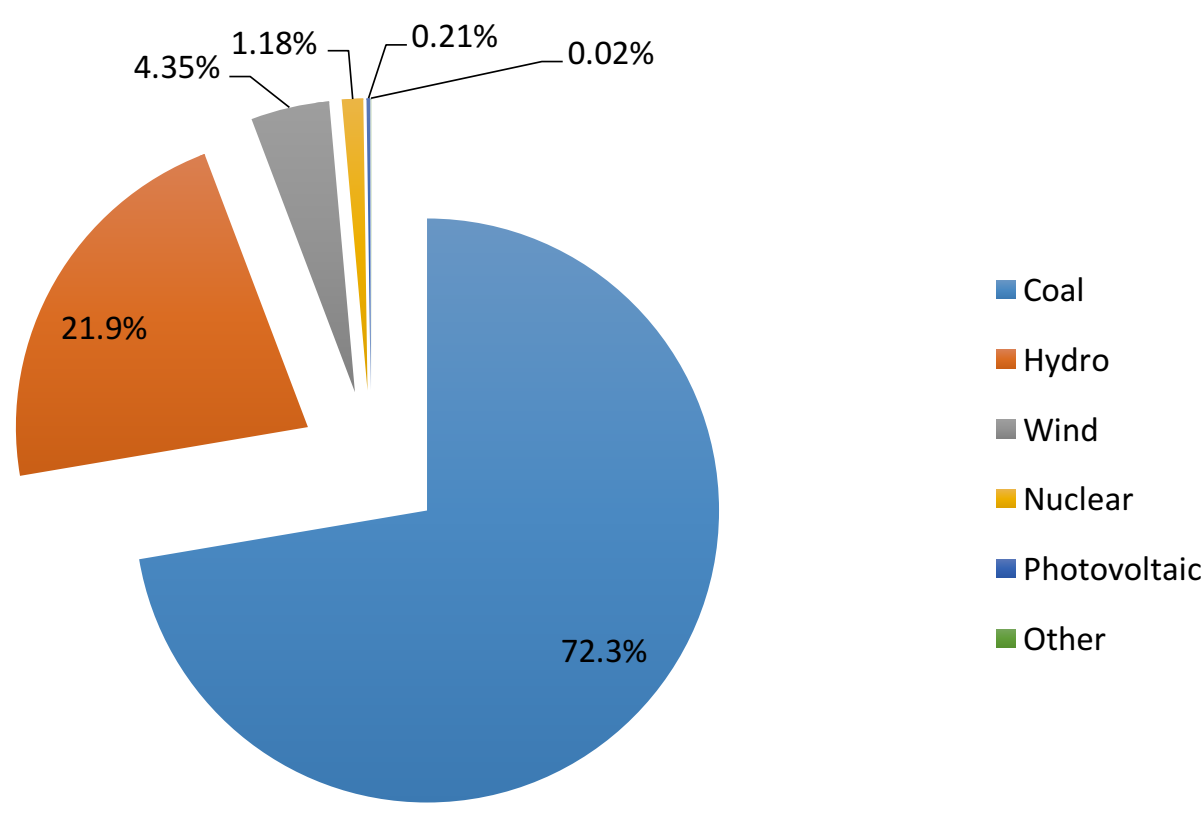

Figure A-1 - Energy supply for China (NEA, 2012). 


\section{Appendix B - Energy Statistics for Ontario, Canada}

Table B-1 - Energy balances for Canada 2013 in thousand tonnes of oil equivalent (ktoe) on a net calorific value basis (OECD/IEA, 2016).

\begin{tabular}{|c|c|c|c|c|c|c|c|c|c|c|c|}
\hline & Coal* $^{*}$ & Crude oil* & Oil products & Natural gas & Nuclear & Hydro & $\begin{array}{l}\text { Geothermal, } \\
\text { solar, etc. }\end{array}$ & $\begin{array}{r}\text { Biofuels and } \\
\text { waste }\end{array}$ & Electricity & Heat & Total $^{* \star}$ \\
\hline Production & 35039 & 195251 & 0 & 130310 & 26787 & 33691 & 1067 & 12920 & 0 & 0 & 435065 \\
\hline Imports & 5355 & 37082 & 10862 & 22290 & 0 & 0 & 0 & 1062 & 1472 & 0 & 78122 \\
\hline Exports & -23421 & -139123 & -24717 & -68836 & 0 & 0 & 0 & -798 & -5772 & 0 & -262667 \\
\hline International marine bunkers ${ }^{\star \star *}$ & 0 & 0 & -408 & 0 & 0 & 0 & 0 & 0 & 0 & 0 & -408 \\
\hline International aviation bunkers ${ }^{* * *}$ & 0 & 0 & -826 & 0 & 0 & 0 & 0 & 0 & 0 & 0 & -826 \\
\hline Stock changes & 399 & -289 & 551 & 3251 & 0 & 0 & 0 & 0 & 0 & 0 & 3911 \\
\hline
\end{tabular}

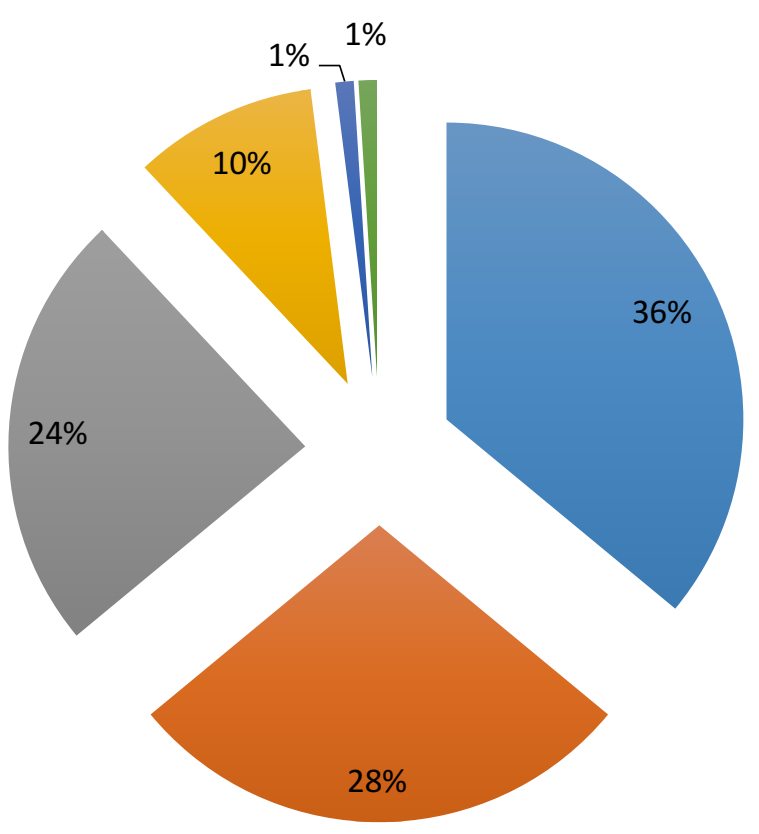

nuclear

- Gas/Oil

Hydro

Wind

Biofuel

Photovoltaic

Figure B-1 - Energy supply for Ontario (IESO, 2015). 


\section{References}

Alsema, E. (2000). Energy Pay-Back Time and CO2 Emissions of PV Systems. Progress in Photovoltaics, 8 (1), 17-25.

Alsema, E., \& de Wild Scholten, J. (2006). Environmental Impacts of Crystalline Silicon Photovoltaic Module Production. 13th CIRP International Conference on Life Cycle Engineering. Leuven, Belgium.

Arvizu, D., P., B., Cabeza, L., Hollands, T., Jäger-Waldau, A., Kondo, M., et al. (2011). Direct Solar Energy. In IPCC Special Report on Renewable Energy Sources and Climate Change Mitigation. Cambridge UK: Cambridge University Press.

Branker, K., \& Pearce, J. (2010). Financial Return for Government Support of Large-Scale Thin-Film Solar Photovoltaic Manufacturing in Canada. Energy Policy, 38, 4291-4303.

Bowels, P., \& Dong, X. (1999). Globalization and Industrial Labour in China: A Critical Review. Canadian Journal of Development Studies, 20, 889-910.

Canadian Solar Inc. (2015). The Canadian Solar Difference. Retrieved 10 21, 2015, from http://www.canadiansolar.com/about.html

CanSIA. (2010). Solar Vision 2025: Beyond Market Competitiveness.

CBSA. (2015, 03 05). Photovoltaic modules and laminates: Dumping and Countervailing (China). Retrieved 05 20, 2016, from Canadian Border Services Agency: http://www.cbsaasfc.gc.ca/sima-lmsi/i-e/ad1405/ad1405-i14-np-eng.html

Ceccaroli, B., \& Lohne, O. (2011). Solar Grade Silicon Feedstock. In A. López, Handbook of Photovoltaic Science and Engineering (pp. 153-204). West Sussex, UK: John Wiley \& Sons, Ltd.

Chan, C.K.C., \& Zhai, Y. (2013). Active Labour Market Policies in China - Towards Improved Labour Protection? Journal of Asian Public Policy, 6, 1, 10-25.

Chen, W., Hong, J., Yuan, X., \& Liu, J. (2016). Environmental Impact Assessment of Monocrystalline Silicon Solar Photovoltaic Cell Production: A Case Study in China. Journal of Cleaner Production, 112, 1025-1032.

Consoli, F., Allen, D., Boustead, J., Fava, J., Franklin, W., Jensen, A., et al. (1994). Guidelines for LifeCycle Assessment: A "Code of Practice". Environmental Science \& Pollution Research, 1 (1), 55.

de Wild Scholten, J. (2013). Energy Payback Time and Carbon Footprint of Commercial Photovoltaic Systems. Solar Energy Materials \& Solar Cells, 119, 296-305.

Delmas, M. (2001). Stakeholders and Competitive Advantage: The Case of ISO 14001. Production and Operations Management, 10 (3), 343-358.

Dubey, S., Jadhav, N., \& Zakirova, B. (2013). Socio-Economic and Environmental Impacts of Silicon Based Photovoltaic (PV) Technologies. Energy Procedia, 33, 322-334.

Environment Canada. (2012). The Assessment of the Environmental Performance of Solar Photovoltaic Technologies.

Finkbeiner, M., Wiedermann, M., \& Saur, K. (1998). A Comprehensive Approach Towards Product and Organization Related Environmental Management Tools. The International Journal of Life Cycle Assessment, 3 (3), 169-178.

Flyvbjerg, B. (2006). Five Misunderstandings About Case-Study Research. Qualitative Inquiry, 12 (2), 219-245. 
Foreign Affairs, Trade and Development Canada. (2016). Canada's State of Trade: Trade and Investment Update - 2015. Government of Canada, Global Affairs Canada. Ottawa: Minister of Public Works and Government Services Canada.

Frankl, P., Menichetti, E., Raugei, M., Lombardelli, S., \& Prennushi, G. (2005). Final Report on Technical Data, Costs and Life Cycle Inventories of PV Applications. New Energy Externalities Developments for Sustainability.

Frischknecht, R., Itten, R., Sinha, P., de Wild-Scholten, M., Zhang, J., Fthenakis, V., et al. (2015). Life Cycle Inventories and Life Cycle Assessment of Photovoltaic Systems. International Energy Agency (IEA).

Fthenakis, V. F., Raugei, M., Kim, H., Alsema, E., Held, M., \& de Wild-Scholten, M. (2011). Methodology Guidelines of Life-Cycle Assessment of Photovoltaic Electricity. International Energy Agency, Photovoltaic Power Systems Programme.

Fthenakis, V., Kim, H., \& Alsema, E. (2008). Emissions from Photovoltaic Life Cycles. Environmental Science \& Technology, 42 (6), 2168-2174.

Fu, Y., Liu, X., \& Yuan, Z. (2015). Life-Cycle Assessment of Multi-Crystalline Photovoltaic (PV) Systems in China. Journal of Cleaner Production, 85, 180-190.

Gerber, L. (2014). Designing Renewable Energy Systems: A Life Cycle Assessment Approach. Lausanne, Switzerland: EPFL Press.

Goswami, Y., \& Besarati, S. (2013). Solar. In W. E. Council, World Energy Resources: 2013 Survey (pp. 326-353). London, UK: World Energy Council.

Government of Canada. (2016, 07 27). Environmental Indicators. Retrieved 08 08, 2016, from Government of Canada: https://www.ec.gc.ca/indicateurs-indicators/default.asp?lang=En

Gribov, B., \& Zinov'ev, K. (2003). Preparation of High-Purity Silicon for Solar Cells. Inorganic Materials, 39 (7), 653-662.

Handfield, R., Walton, S., Seegers, L., \& Melnvk, S. (1997). 'Green' Value Chain Practices in the Furniture Industry. Journal Operations Management, 15, 293-315.

Hondo, H. (2005). Life Cycle GHG Emission Analysis of Power Generation Systems: Japanese Case. Energy, 30 (11-12), 2042-2056.

IEA. (2011). Solar Energy Perspectives. Paris, France: International Energy Agency.

IEA. (2015). Trends 2015 Photovoltaic Applications - Survey Report of Selected IEA Countries Between 1992 and 2014. International Energy Agency Photovoltaic Power Systems Programme.

IESO. (2014, 07 25). Changes Relating to Domestic Content Requirements for microFIT After July 25, 2014. Retrieved 05 20, 2016, from microFIT Program: http://microfit.powerauthority.on.ca/faqs/microfit-domestic-content-after-25-july-2014

IESO. (2015). Power Data - Supply Overview. Retrieved 10 21, 2015, from Independent Electricity System Operator: http://www.ieso.ca/Pages/Power-Data/Supply.aspx

IPCC. (2011). Summary for Policymakers. In IPCC Special Report on Renewable Energy Sources and Climate Change Mitigation. Cambridge: Cambridge University Press.

ISO 14001. (2015). ISO 14001:2015(en) Environmental Management Systems - Requirements with Guidance for use. International Organization of Standardization.

ISO 14040. (2006). Environmental Management - Life Cycle Assessment - Principles and Framework. International Organization of Standardization. 
Iwata, K., Arimura, T., \& Hibiki, S. (2010). An Empirical Analysis of Determinants of ISO 14001 Adoption and its Influence on Toluene Emission Reduction. Japan Center for Economic Research, 62, 16-38.

Jungbluth, N., Stucki, M., Frischknecht, R., \& Büsser, S. (2010). Photovoltaics. Swiss Centre for Life Cycle Inventories. Uster, Switzerland: ESU-services Ltd.

Khattak, C., Joyce, D., \& Schmid, F. (2001). Production of Solar Grade (SoG) Silicon by Refining Liquid Metallurgical Grade (MG) Silicon. National Renewable Energy Laboratory. U.S. Department of Energy.

King, A., Lenox, M., \& Terlaak, A. (2005). The Strategic Use of Decentralized Institutions: Exploring Certification with the ISO 14001 Management Standard. Academy of Management Journal, 48, 1091-1106.

Klöpffer, W. (2012). The Critical Review of Life Cycle Assessment Studies According to ISO 14040 and 14044. The International Journal of Life Cycle Assessment, 17 (9), 1087-1093.

Klöpffer, W. (2006). The Role of SETAC in the Development of LCA. International Journal of Life Cycle Assessment, 11 (1), 116-122.

Klöpffer, W., \& Rippen, G. (1992). Life Cycle Analysis and Ecological Balance: Methodical Approaches to Assessment of Environmental Aspects of Products. Environmental International, $18,55-61$.

Kreith, F., \& Kreider, J. (1978). Principles of Solar Engineering. Washington: Hemisphere Publishing Corporation.

Labouret, A., \& Villoz, M. (2010). Solar Photovoltaic Energy (IET Renewable Energy. (J. Hamand, Trans.) London, UK: The Institution of Engineering and Technology.

Lenio, M. (2014). Solar in Sight. Alternatives Journal, 40 (5), 50-52.

Lindsey, R. (2009, 01 14). Climate and Earth's Energy Budget. Retrieved 11 25, 2015, from NASA Earth Observatory: http://earthobservatory.nasa.gov/Features/EnergyBalance/page1.php

Lloyd, B., \& Forest, A. (2010). The Transition to Renewables: Can PV Provide an Answer to the Peak Oil and Climate Change Challenges? Energy Policy, 38, 7378-7394.

Marsmann, M. (2000). The ISO 14040 Family. International Journal of Life Cycle Assessment, 5 (6), 317-318.

Ministry of Energy. (2013). Achieving Balance - Ontario's Long-Term Energy Plan. Toronto: Queen's Printer for Ontario.

Moomaw, W., Yamba, F., Kamimoto, M., Maurice, L., Nyboer, J., Urama, K., et al. (2011). Introduction. In IPCC Special Report on Renewable Energy Sources and Climate Change Mitigation. Cambridge: Cambridge University Press.

Murray, B., \& Rivers, N. (2015). British Columbia's Revenue-Neutral Carbon Tax: A Review of the Latest "Grand Experiment" in Environmental Policy. Energy Policy, 86, 674-683.

NASA. (2015). Global Maps - Net Radiation. Retrieved 01 10, 2016, from NASA Earth Observatory: http://earthobservatory.nasa.gov/GlobalMaps/view.php?d1=CERES_NETFLUX_M

Navigant Consulting Inc. (2012). Sector Profile for Solar Photovoltaics in Canada. Canmet ENERGY, Natural Resources Canada.

Nawrocka, D., Brorson, T., \& Lindhqvist, T. (2009). ISO 14001 in Environmental Supply Chain Practices. Journal of Cleaner Production, 17, 1435-1443.

NEA. (2012, 11 05). Constantly optimize the power structure. Retrieved 0610,2016 , from National Energy Administration: http://www.nea.gov.cn/2012-11/05/c_131951202.htm 
Nguyen, H., \& Pearce, J. (2010). Estimating Potential Photovoltaic Yield with r.sun and Open Source Geographical Resources Analysis Support System. Solar Energy, 84, 831-843.

NRCan. (2013, 12 23). PV Potential and Insolation. Retrieved 01 10, 2016, from Natural Resources Canada: http://pv.nrcan.gc.ca/pvmapper.php?LAYERS=2057,4240\&SETS=1707,1708,1709,1710,1122\& ViewRegion=-

$2508487 \% 2 \mathrm{C} 5404897 \% 2 \mathrm{C} 3080843 \% 2 \mathrm{C} 10464288 \&$ title_e=PV+potential+and+insolation \&title $\mathrm{f}=$ Potentiel+photovolta $\% \mathrm{C} 3 \% \mathrm{AFque}+\mathrm{et}+$ ensoleillement\&lang=e

NSSDC. (2014). Vangaurd 1. Retrieved 12 5, 2015, from

http://nssdc.gsfc.nasa.gov/nmc/spacecraftDisplay.do?id=1958-002B

Nugent, D., \& Sovacool, B. (2014). Assessing the Lifecycle Greenhouse Gas Emissions from Solar PV and Wind Energy: A Critical Meta-Survey. Energy Policy , 65, 229-244.

OECD/IEA. (2016). Statistics. Retrieved 05 02, 2016, from International Energy Agency: http://www.iea.org/stat

Pacca, S., Sivaraman, D., \& Keoleian, G. (2006). Life Cycle Assessment of the $33 \mathrm{~kW}$ Photovoltaic System on the Dana Building at the University of Michigan: Thin Film Laminates, Multi-crystalline Modules, and Balance of Systems Components. University of Michigan, Center for Sustainable Systems, Ann Arbor MI.

PE International. (2010, September). GaBi Education: Handbook for Life Cycle Assessment (LCA). Leinfelden-Echterdingen, Germany.

Pehnt, M. (2006). Dynamic Life Cycle Assessment (LCA) of Renewable Energy Technologies. Renewable Energy, 31 (1), 55-71.

Perriman, R. (1993). A Summary of SETAC Guidelines for Life Cycle Assessment. Journal of Cleaner Production, 1 (3-4), 209-212.

Photowatt. (n.d.). Cells. Retrieved 01 07, 2016, from Photowatt: http://www.photowatt.com/en/products/cells.html

Poissant, Y., \& Bateman, P. (2014). 2014 National Survey Report of PV Power Applications in Canada. International Energy Agency, Photovoltaic Power Systems Programme.

Pollin, R., \& Garrett-Peltier, H. (2009). Building the Green Economy: Employment of Green Energy Investments for Ontario.

Porter, M. (1996). What is Strategy? Harvard Business Review, 74 (6), 61-78.

Porter, M., \& Millar, V. (1985). How Information Gives You a Competitive Advantage. Harvard Business Review, 63 (4), 149-160.

Porter, M., \& van der Linde, C. (1995). Green and Competitive: Ending the Stalemate. Harvard Business Review, 73 (5), 120-134.

Potoski, M., \& Prakash, A. (2013). Do Voluntary Programs Reduce Pollution? Examining ISO 14001's Effectiveness Across Countries. Policy Studies Journal, 41 (2), 273-294.

Psomas, E., Fotopoulos, C., \& Kafetzopoulos, D. (2011). Motives, Difficulties and Benefits in Implementing the ISO 14001 Environmental Management System. Management of Environmental Quality: An International Journal, 22 (4), 502-521.

Rezaee, Z., \& Elam, R. (2000). Emerging ISO 14000 Environmental Standards: A Step-by-Step Implementation Guide. Managerial Auditing Journal, 15 (1), 60-67.

Rondinelli, D., \& Vastag, G. (2000). Panacea, Common Sense, or Just a Label? The Value of ISO 14001 Environmental Management Systems. European Management Journal, 18 (5), 499-510. 
Rosenbloom, D., \& Meadowcroft, J. (2014). Harnessing the Sun: Reviewing the Potential of Solar Photovoltaics in Canada. Renewable and Sustainable Energy Reviews, 40, 488-496.

Shukla, R., \& Mali, S. (2015). Planning Skills for Solar Supply Chain Management. Indian Journal of Commerce \& Management Studies, 6 (3), 53-57.

Silicor Materials. (2012). About Us: Company History. Retrieved Mar 15, 2016, from Silicor Materials: http://www.silicormaterials.com/about/company-overview.html

SolarGIS. (2016). SolarGIS. Retrieved 05 16, 2016, from GIS data and maps: http://solargis.com/products/maps-and-gis-data/free/overview/

Stake, R. (1995). The Art of Case Study Research. Sage.

Statistics Canada. (2015, 09 29). Summary Tables. Retrieved 12 05, 2015, from http://www.statcan.gc.ca/tables-tableaux/sum-som/101/cst01/demo02a-eng.htm

Stoppato, A. (2008). Life Cycle Assessment of Photovoltaic Electricity Generation. Energy, 33 (2), 224-232.

Stylos, N., \& Koroneos, C. (2014). Carbon Footprint of Polycrystalline Photovoltaic Systems. Journal of Cleaner Production, 64, 639-645.

Szwilski, T. (2000). Using Environmental Management Systems to Systematically Improve Operational Performance and Environmental Protection. International Journal of Surface Mining, Reclamation and Environment, 14, 183-191.

Szymanski, M., \& Tiwari, P. (2004). ISO 14001 and the Reduction of Toxic Emissions. Policy Reform, 7 (1), 31-42.

Testa, F., Rizzi, F., Daddi, T., \& Gusmerotti, N. I. (2014). EMAS and ISO 14001: The Differences in Effectively Improving Environmental Performance. Journal of Cleaner Production, 68, 165-173.

To, W., \& Lee, P. (2014). Diffusion of ISO 14001 Environmental Management Systems: Global, Regional and Country-Level Analyses. Journal of Cleaner Production, 66, 489-498.

Tsoutsos, T., Frantzeskaki, N., \& Gekas, V. (2005). Environmental Impacts from the Solar Energy Technologies. Energy Policy, 33 (3), 289-296.

U.S. DOE. (2015). SunShot: Photovoltaics. Retrieved 02 02, 2016, from Office of Energy Efficiency \& Renewable Energy: http://energy.gov/eere/sunshot/photovoltaics

United Nations. (2015). World Population Prospects: The 2015 Revision, World Population 2015 Wallchart. Department of Economic and Social Affairs Population Division.

Verbruggen, A., Moomaw, W., \& Nyboer, J. (2011). Annex I: Glossary, Acronyms, Chemical Symbols and Prefixes. In IPCC Special Report on Renewable Energy Sources and Climate Change Mitigation. Cambridge: Cambridge University Press.

WEC. (2015). Energy Resources - Solar. Retrieved 10 21, 2015, from World Energy Council: https://www.worldenergy.org/data/resources/resource/solar/

Wiginton, L., Nguyen, H., \& Pearce, J. (2010). Quantifying Solar Photovoltaic Potential on a Large Scale for Renewable Energy Regional Policy. Computers, Environment and Urban Systems, 34, 345-357.

Wong, J., Royapoor, M., \& Chan, C. (2016). Review of Life Cycle Analyses and Embodied Energy Requirement of Single-Crystalline and Multi-Crystalline Silicon Photovoltaic Systems. Renewable and Sustainable Energy Reviews, 608-618.

Yang, D., Liu, J., Yang, J., \& Ding, N. (2015). Life-Cycle Assessment of China's Multi-Crystalline Silicon Photovoltaic Modules Considering International Trade. 94, 35-45.

Yin, R. (1993). Applications of Case Study Research. Sage. 
Yin, R. (2013). Case Study Research: Design and Methods. Sage.

Yue, D., You, F., \& Darling, S. (2014). Domestic and Overseas Manufacturing Scenarios of Siliconbased Photovoltaics: Life Cycle Energy and Environmental Comparative Analysis. Solar Energy, 105, 669-678. 